روّلّى قهيرانى دارايى لله جيابووزلهوهى هاوسلهرانلا

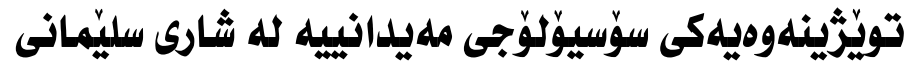

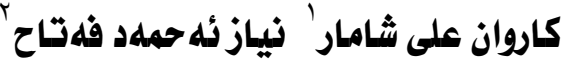

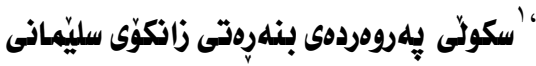

karwanalishamar@gmail.com nyaz.fattah@univsaul.edu.iq

هوخته

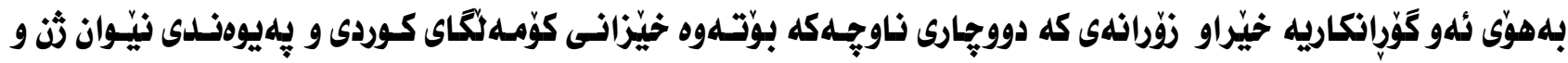

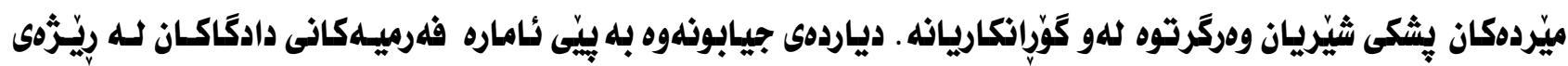

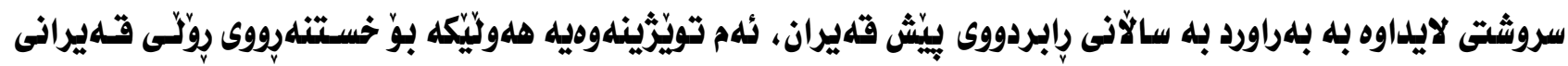

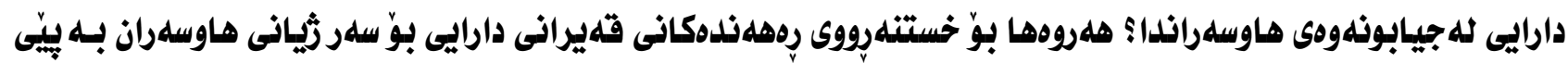

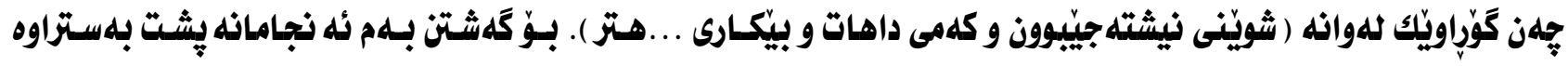

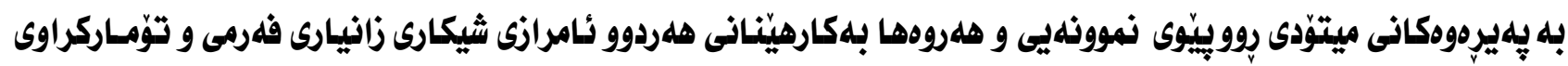

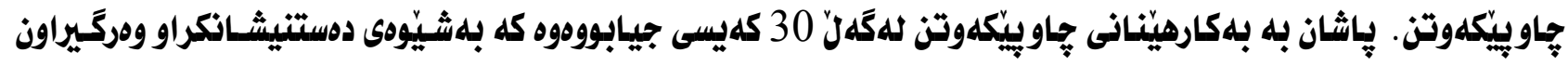

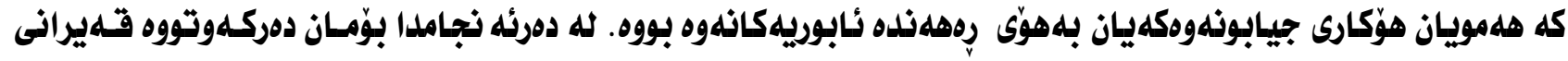

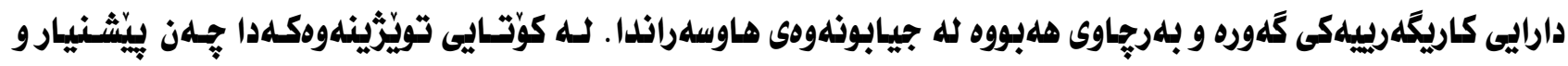

راسيّاردهيهك خراوهتهوروو.

كليلى ووثشهكان : روّل، قهيران، هـاوسلهركيرى، بلهشى بـاخجهى منالان

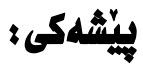

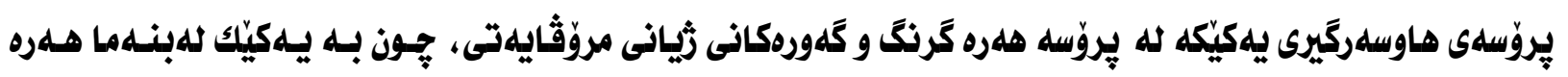

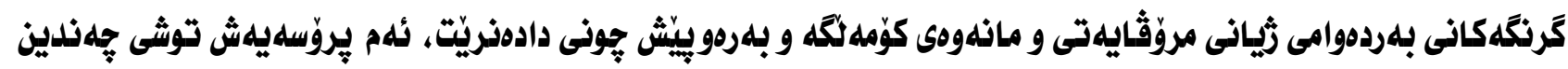

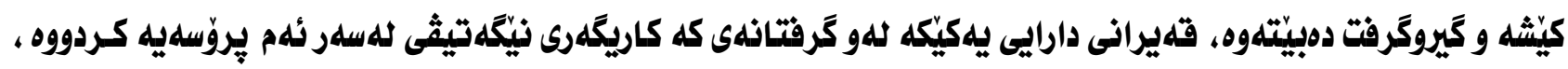

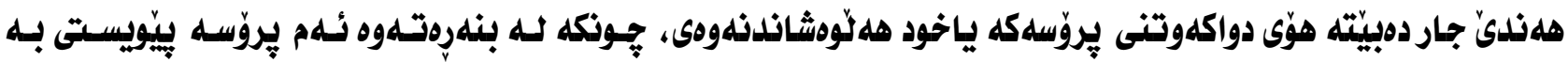

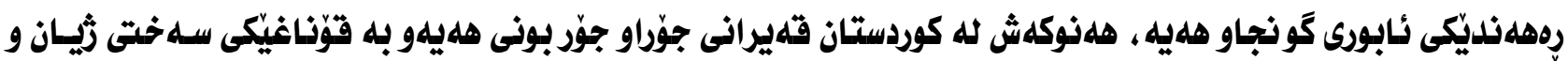
كَوزرانى هاولآتياندا تينيهردهبيّيت.

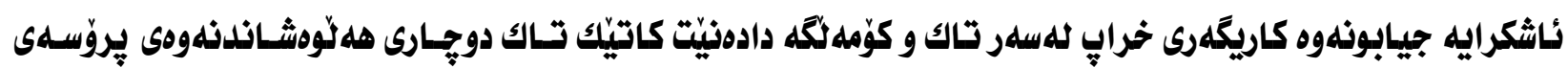

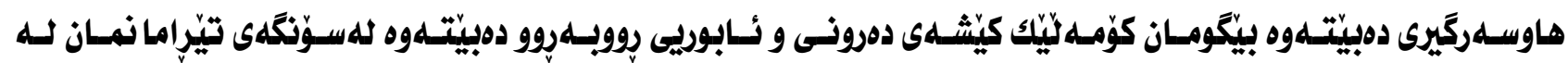

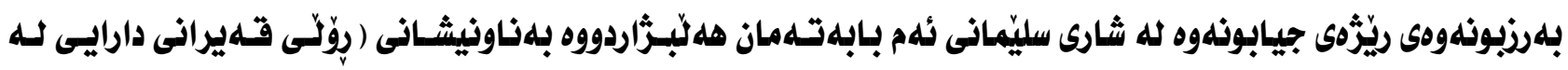

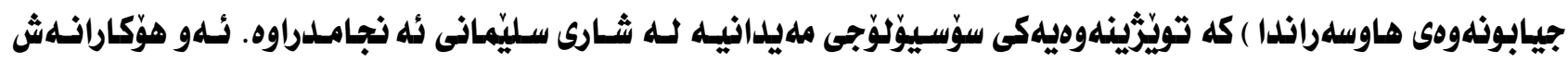




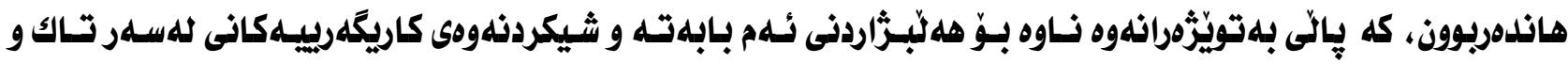

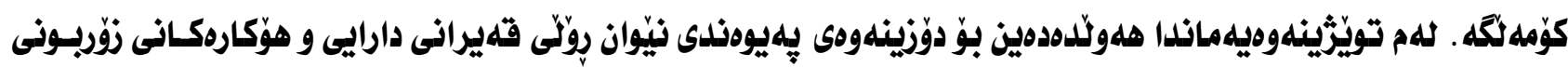

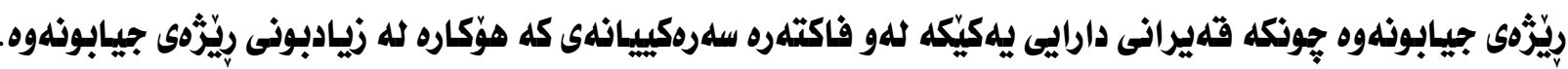

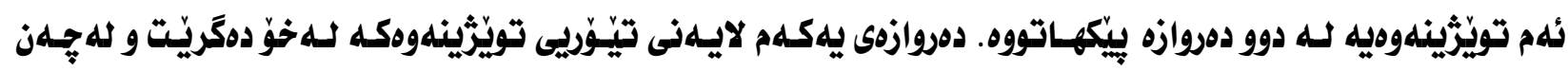

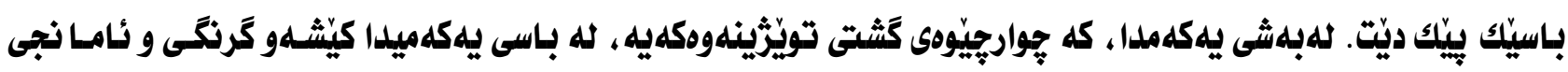

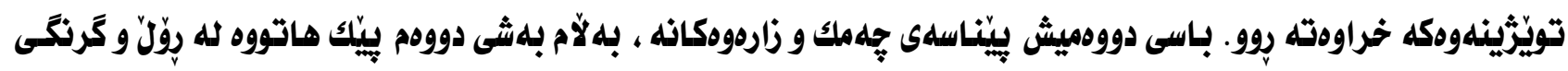

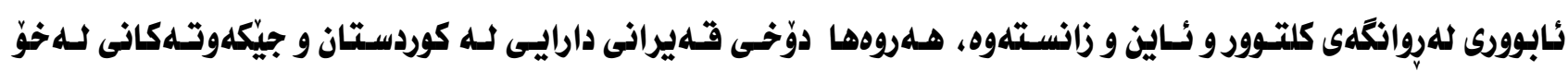

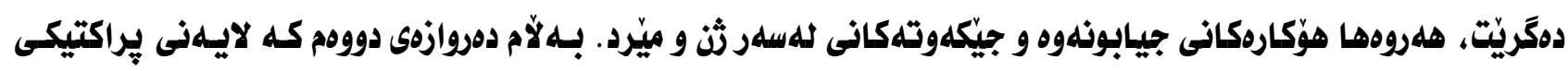

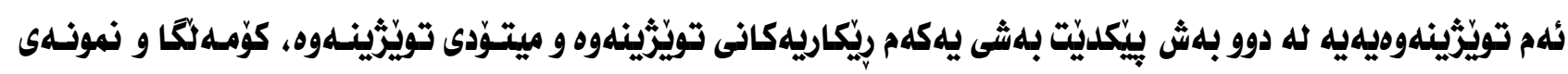

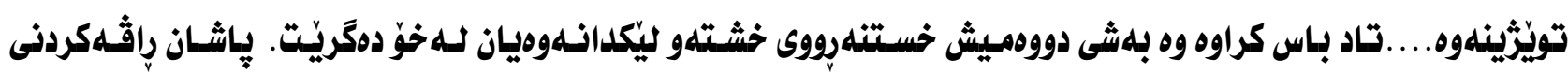

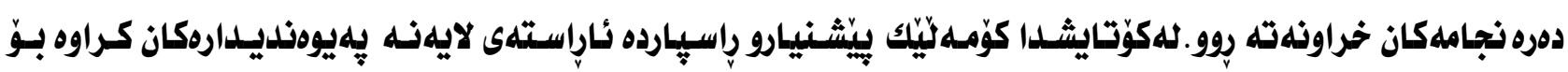

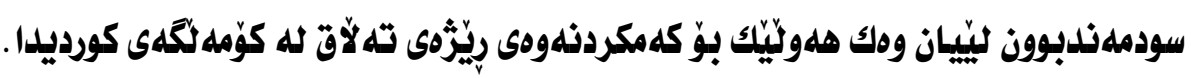

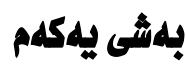

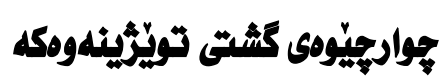

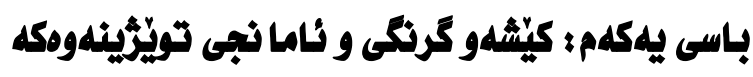

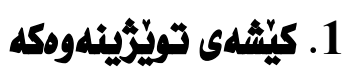

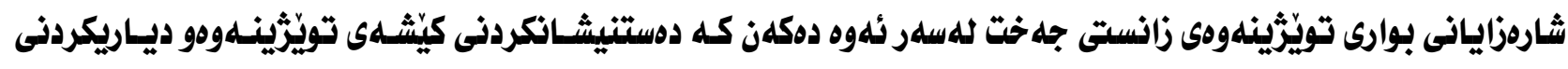

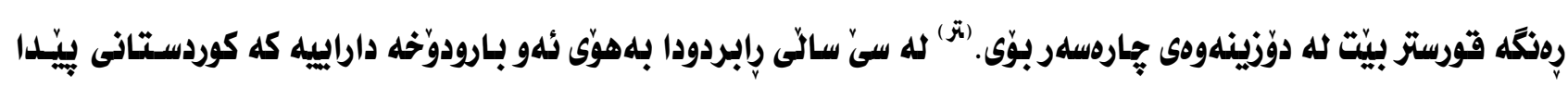

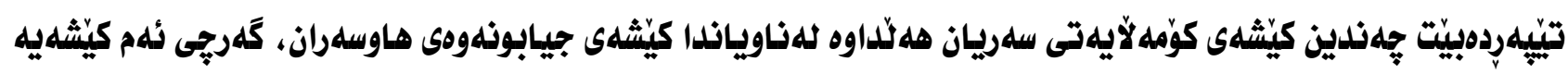

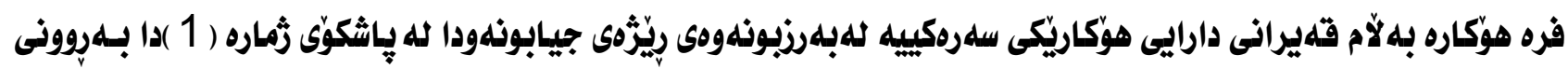

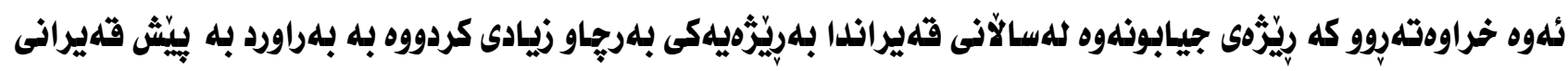

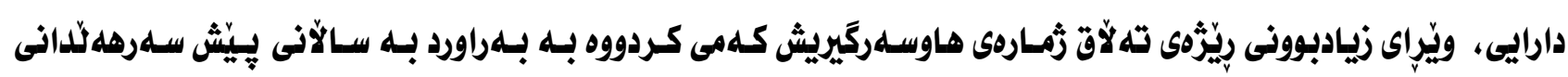

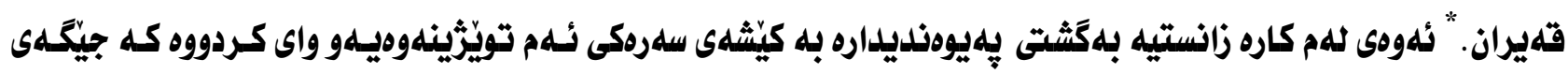

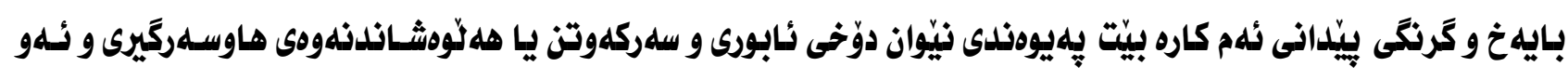

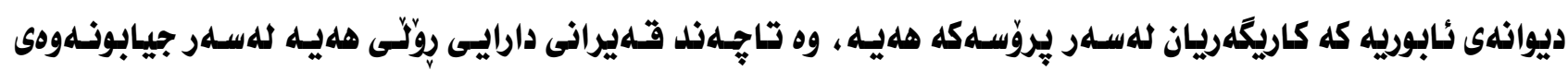

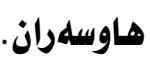

1 عبداللة محمد الشريف، مناهج البحث العلمي ( دليـل الطالب في كتابـة الآبحـاث والرسـائل العلميـة )، مكتبـة للطباعـة و النثر و التوزيـع،

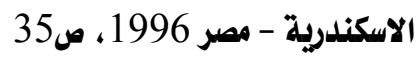

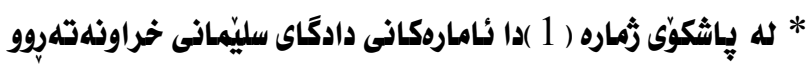




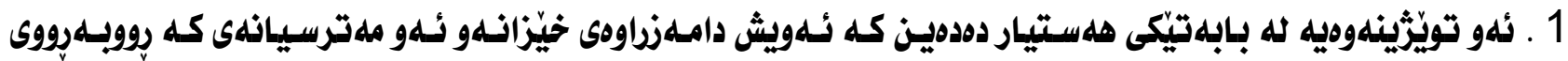
دوبيتّهوه.

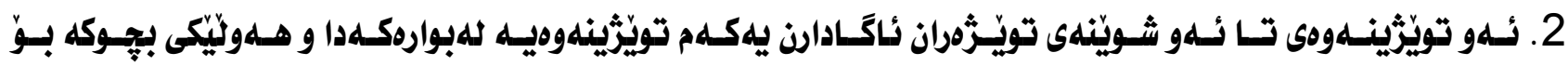

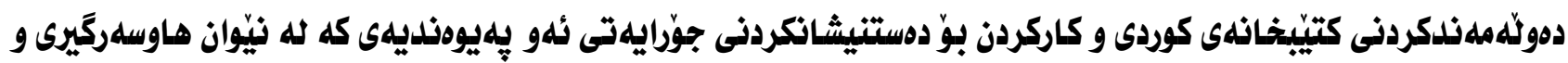
ردهاندى نابوريدا هلهيه.

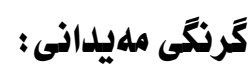

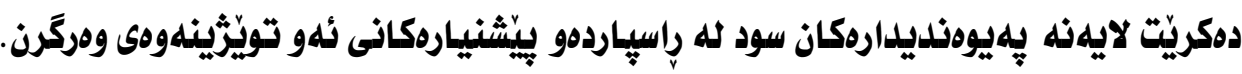

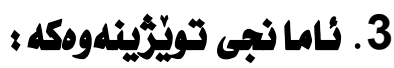

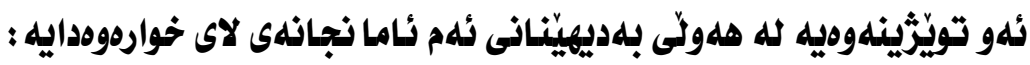

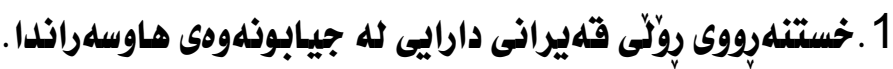

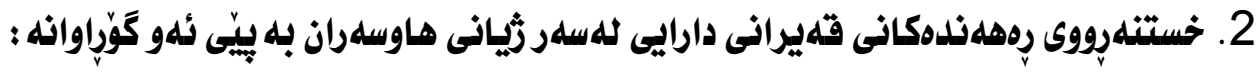

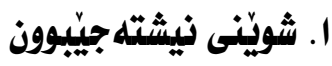

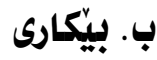
ج. كوّج

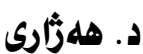

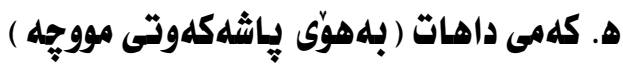
باسى دووهم: يِيّناسلهى جهمك و زارموهكان תูوّل

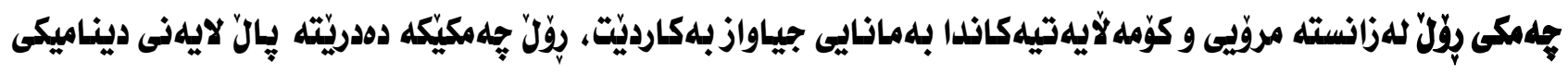

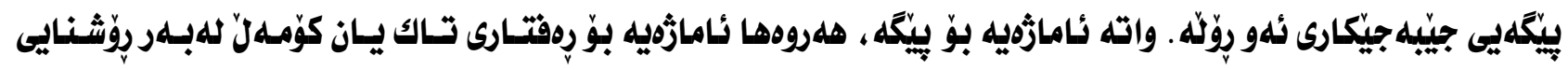

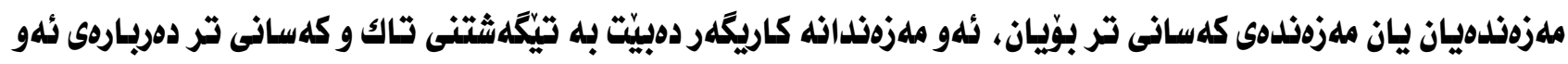

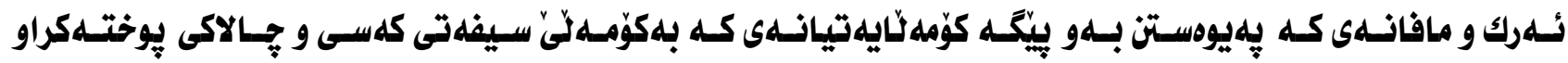

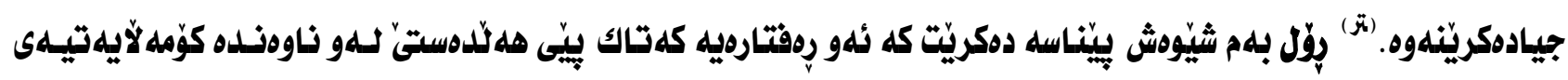




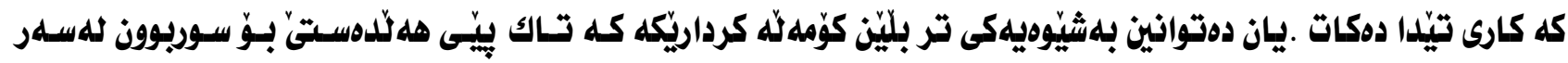

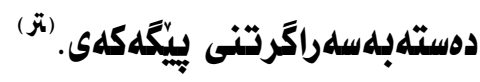
تهيراخى دارايى

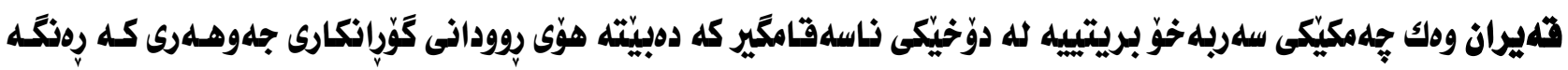

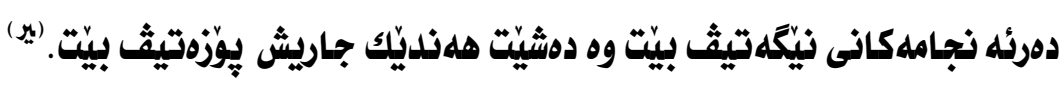
قديرانى دارايى بريتييه له ذارووخانى سيستهمى دارايى، كه يهيوهسته به سهرنهكهوتنى دامهزراوه دارايى و ناداراييهكان

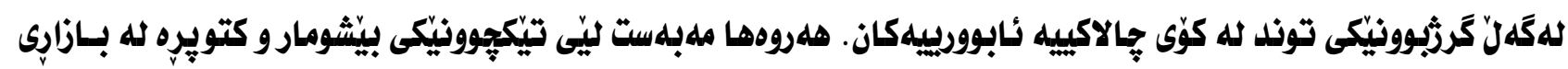

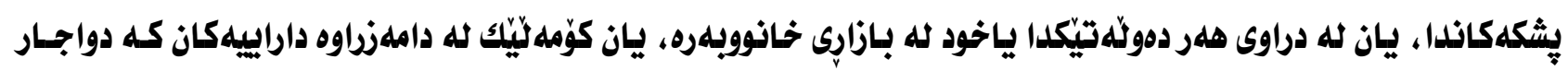

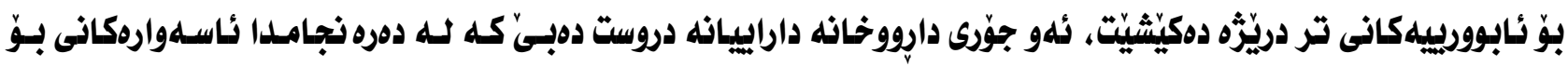

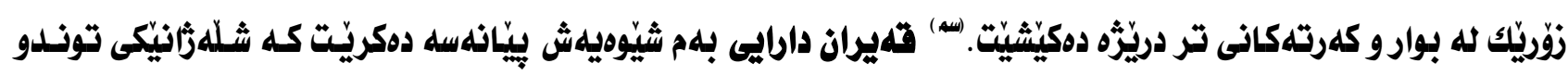

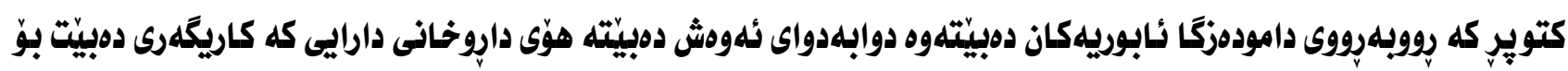
سلهر سيكته روكانى تر

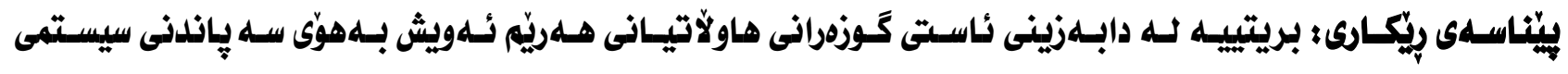

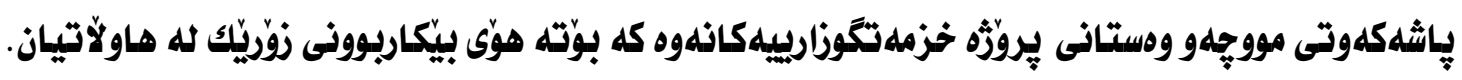
جيابورةوه

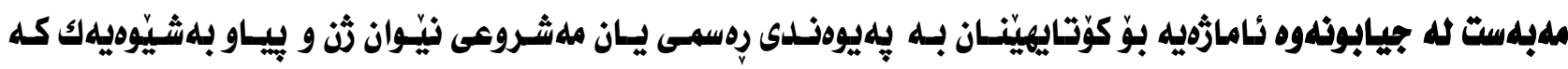

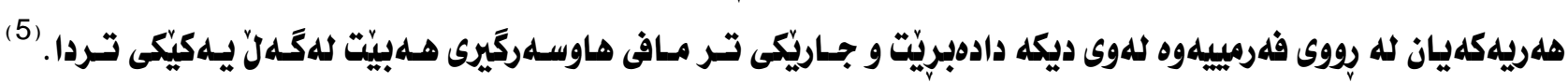

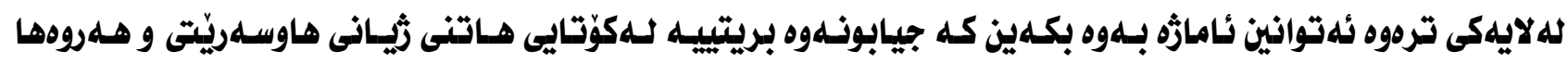

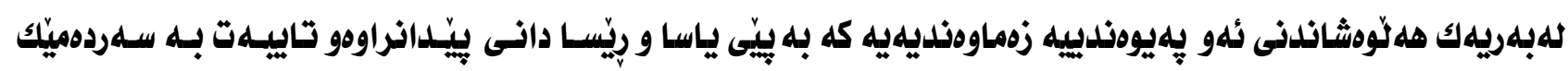
جيّبه جى كراوه.

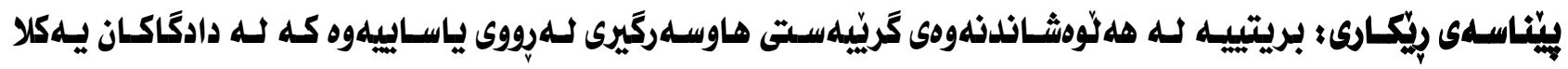
دهريّنهوه.

1 انور محمد علي، دور التربية في التفير الآجتماعي، مجلة كليـة العلـوم الآسلامية، المجلد السـاد،، العـد الثـاني العشر، العراق - الموصل

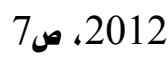

2 شومان منذر، الأعلام والأزمات، مدخل نظري وممارسات عملية، دار الكتب العلمية للنشر والتوزيع، القاهرة 2003، صائراني

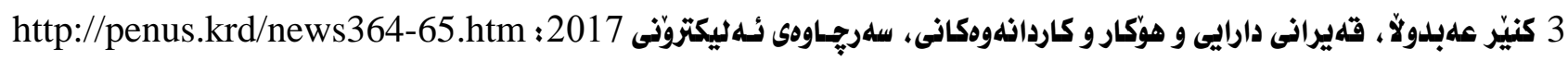

(2017-4-10) 4 فريلد كورتل، الآزمة المالية مفهومها واسبابها وانعكاساتها علي البلدان العربية، مجلة كليـة بغـلداد للعلوم الاقتصـادية الجامعة، عـد 2008،

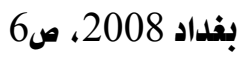

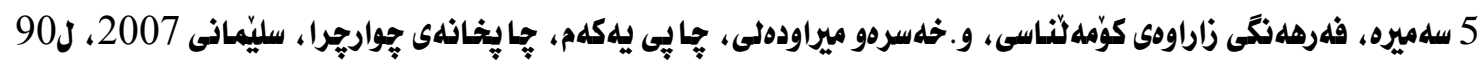

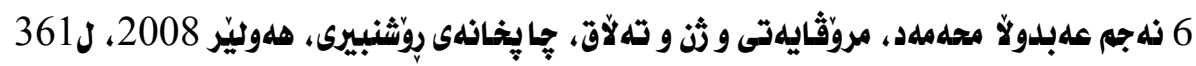




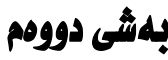

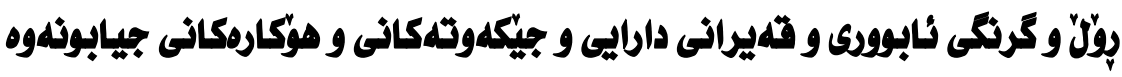

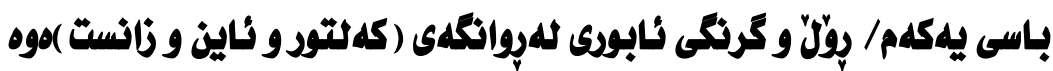

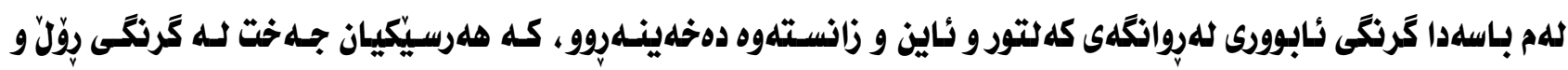

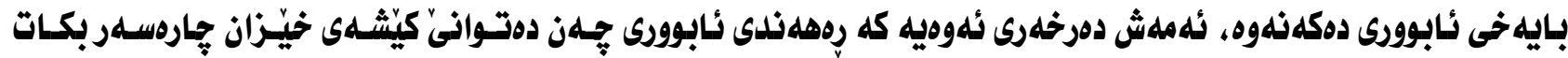

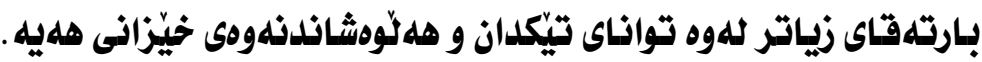

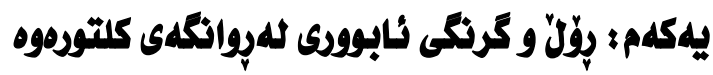

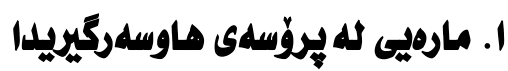

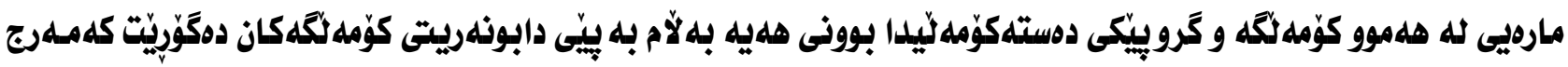

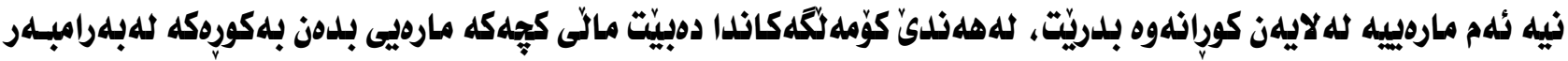

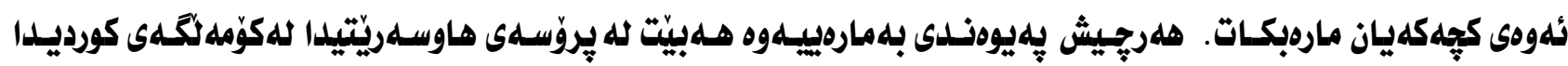

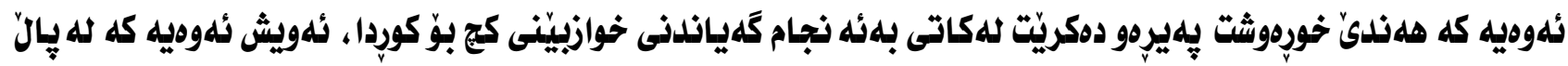

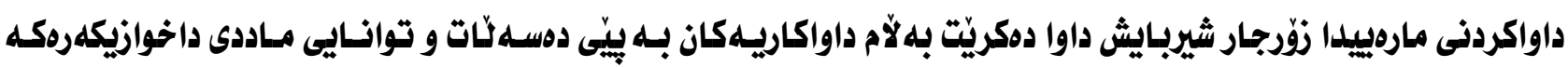

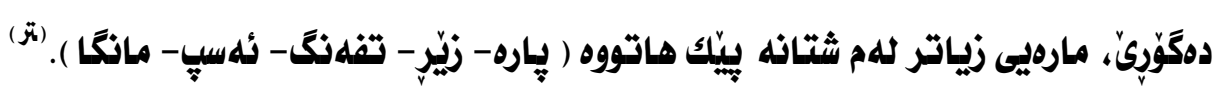

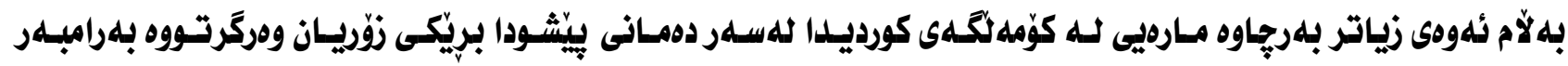

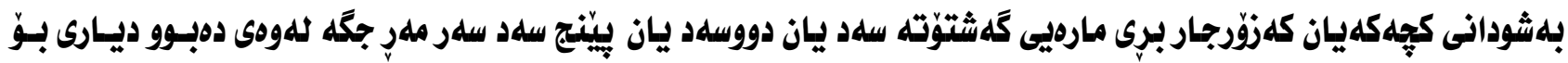

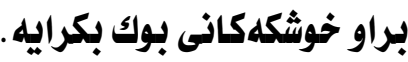

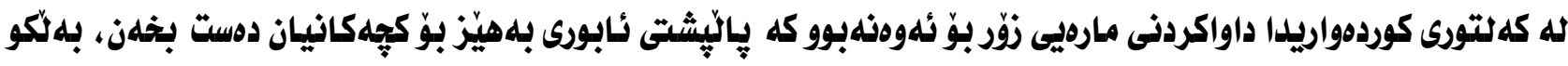

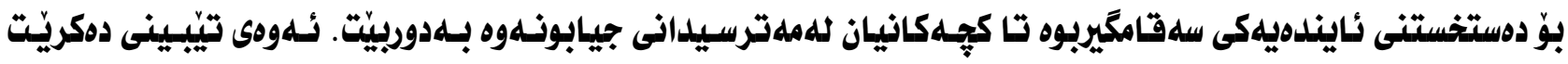

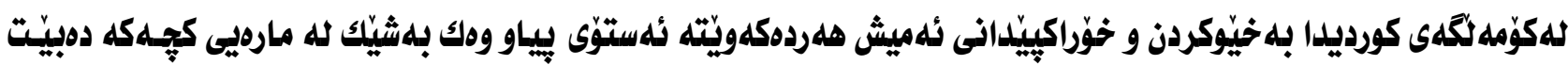
بوَى دوستهبهر بكريّت.

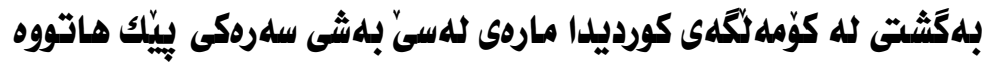

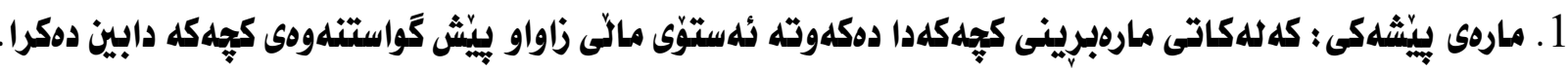
2.

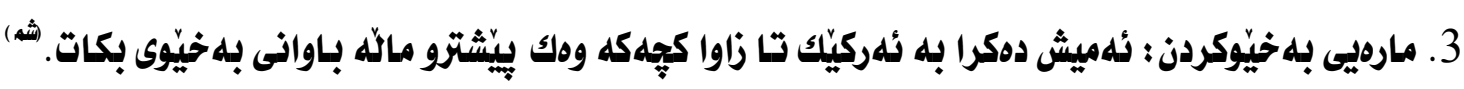

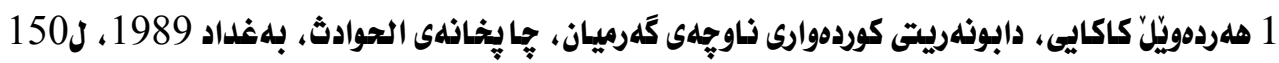

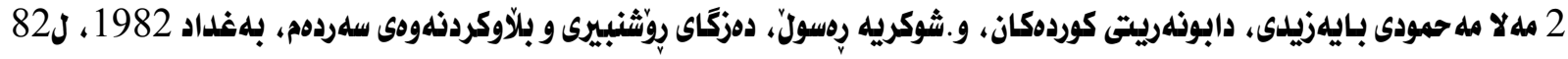

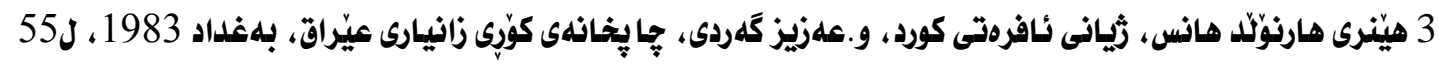

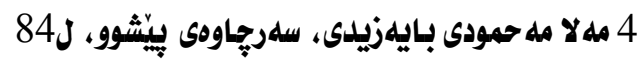




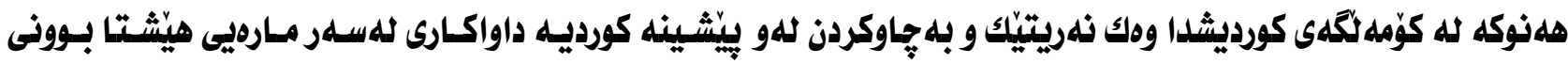

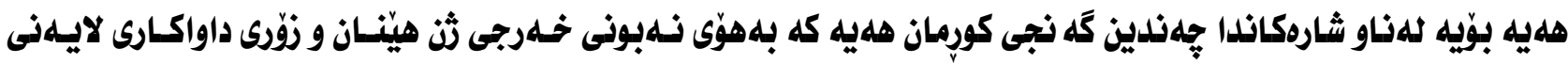
بلدرامبهر هاوسهركيرى ناكلهن ياخود دواى دهخلن.

ب. سامان و دارايق و كاريكهرى لههالباراردنى هاوسهردا

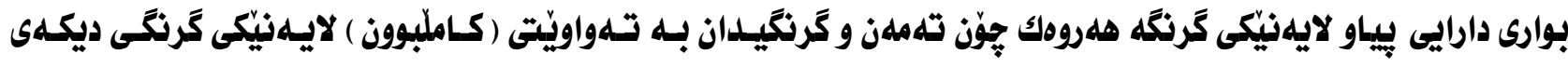

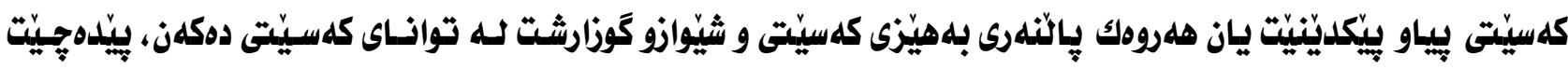

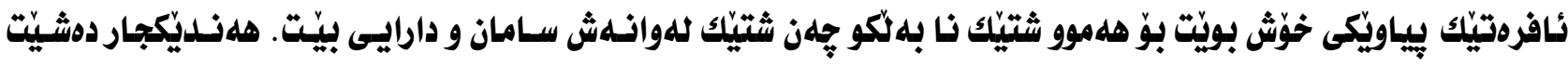

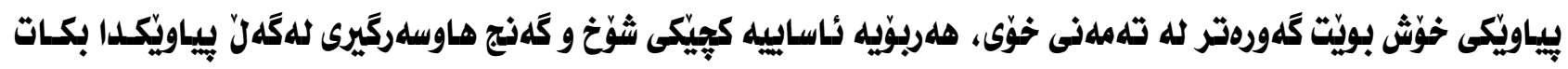

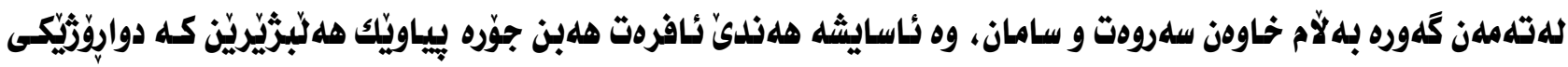

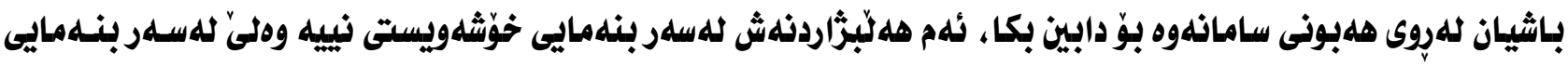

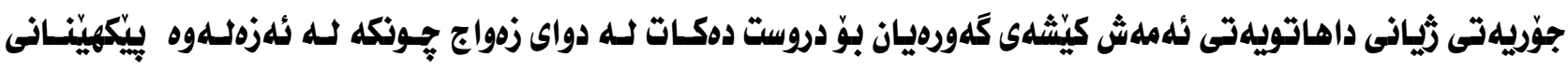

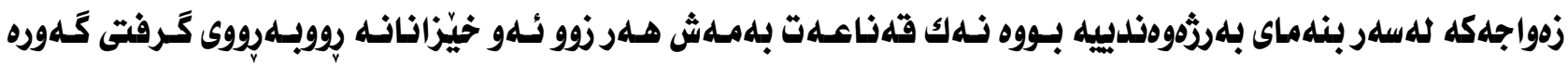

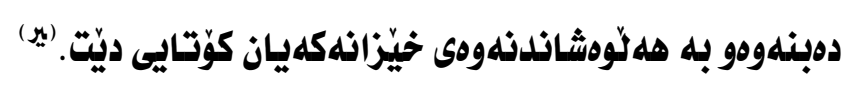

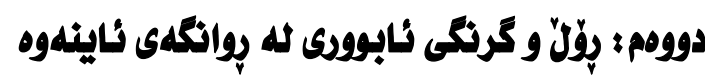

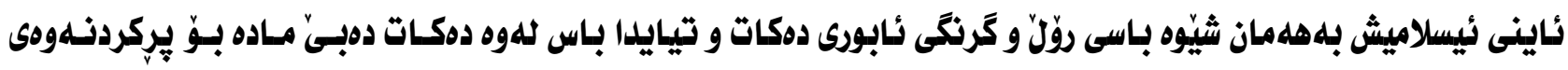

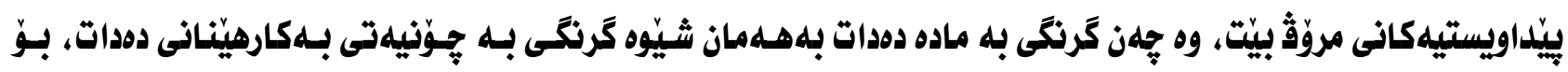

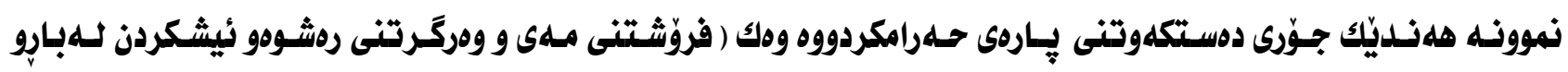

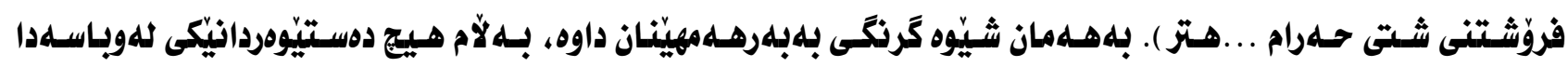

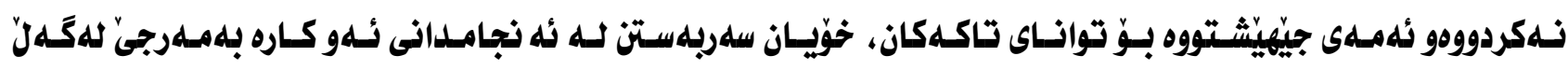

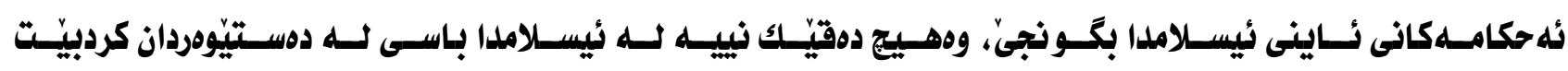

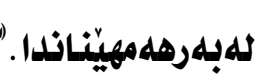

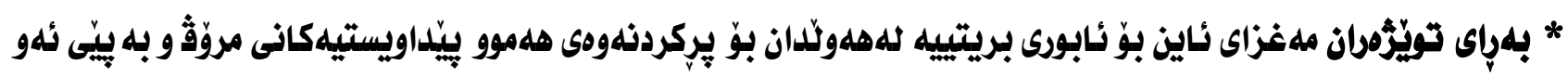

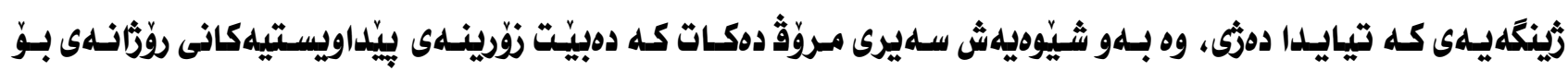

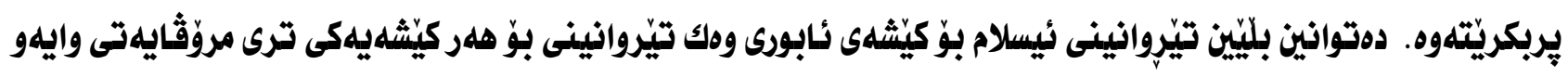

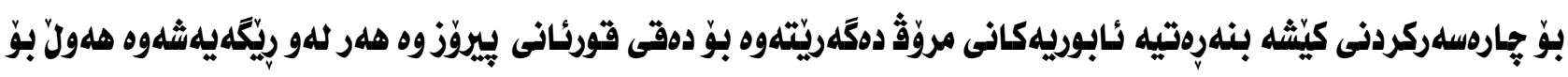

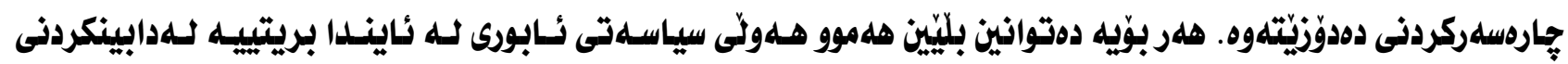

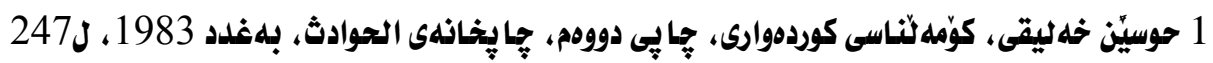

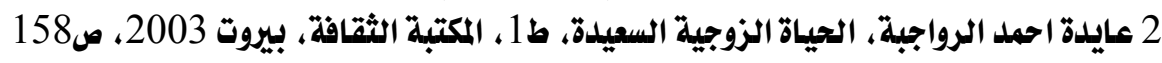

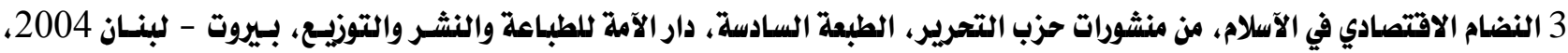




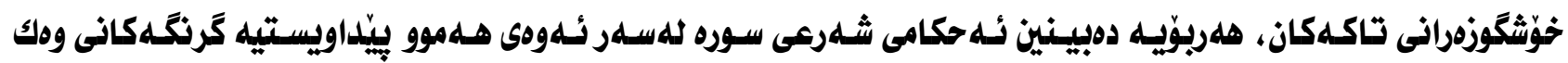

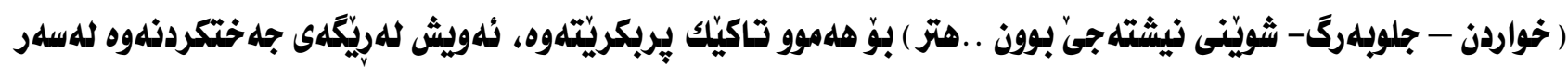

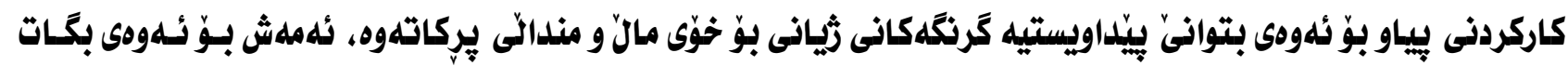

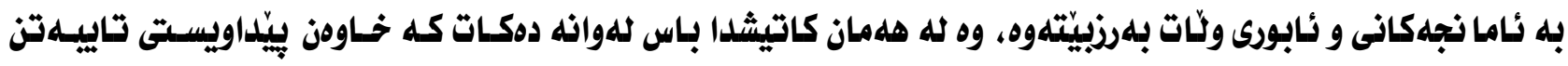

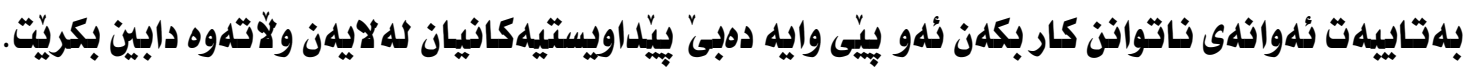

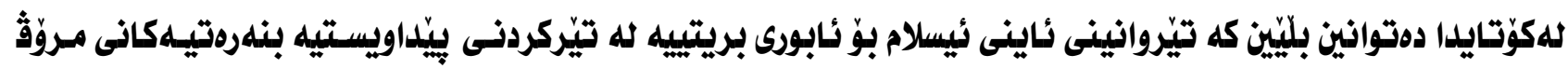

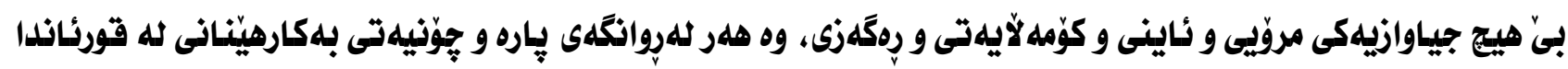

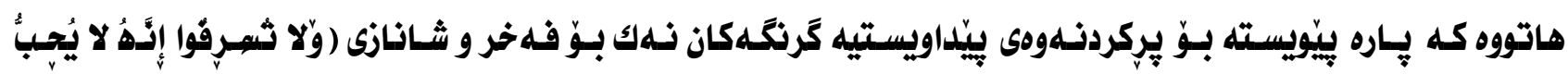

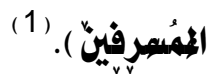

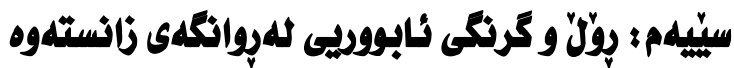

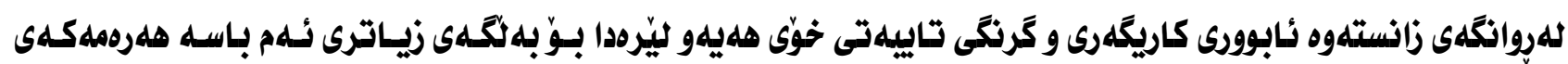

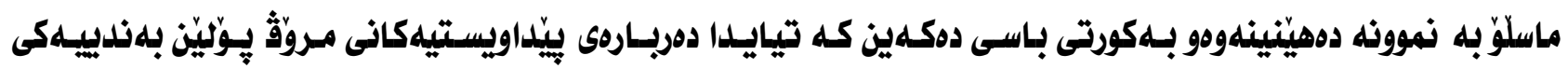

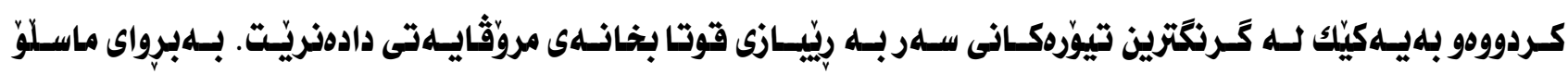

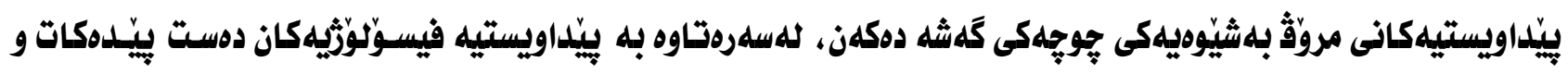

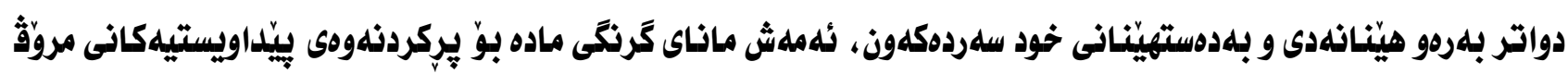

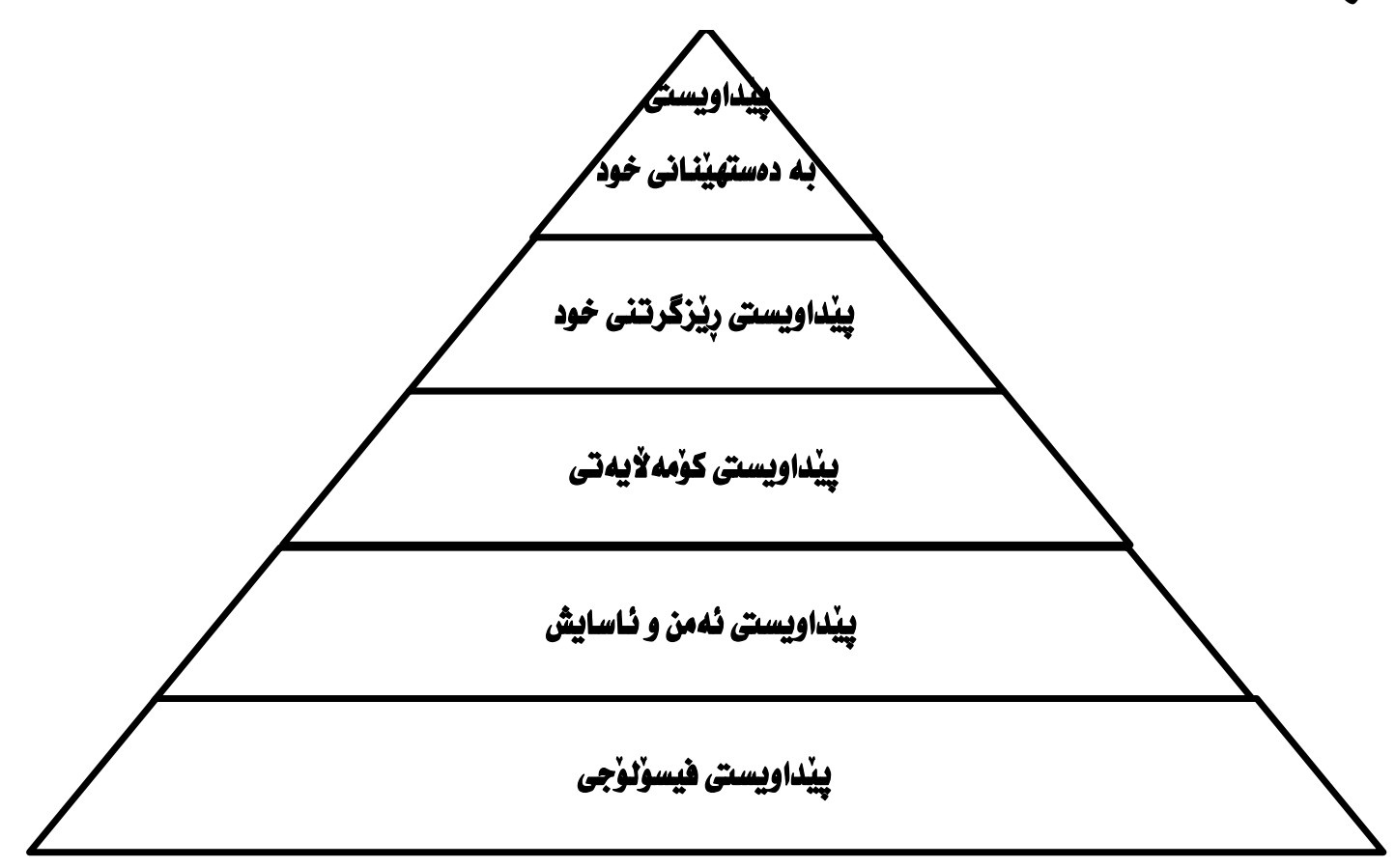

11 القرآن الكريب، سورة الآعراف، الآية 31

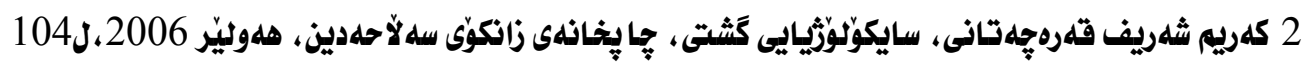




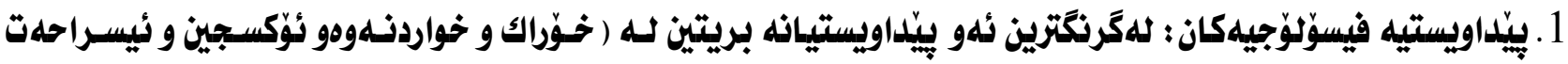

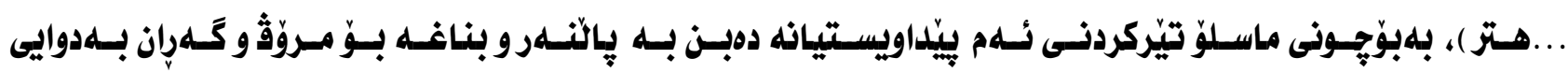

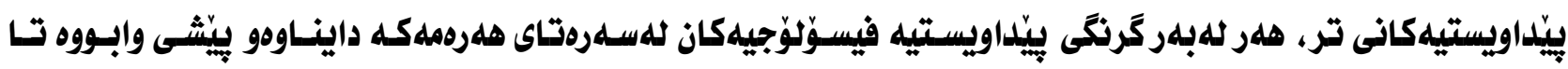
خانهى يهكهم تيّر نهكريّت ناتوانريّت بكَهين به خانهكانى تر.

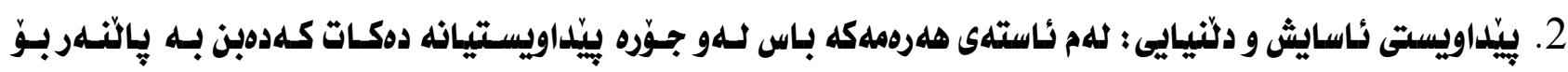

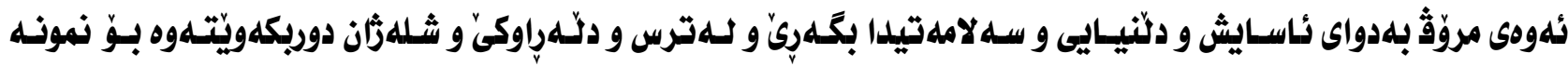

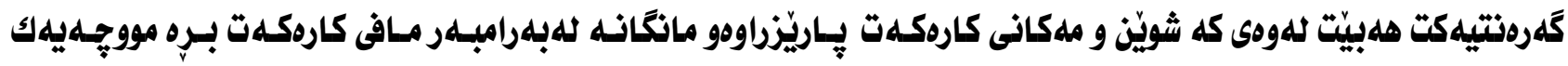
وهردوكريت.

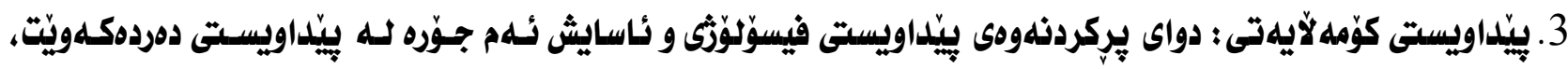

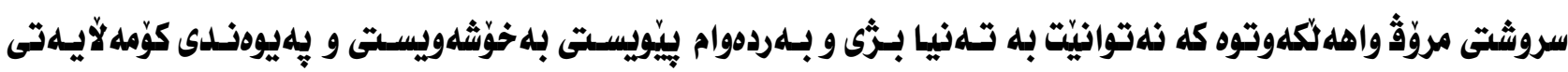

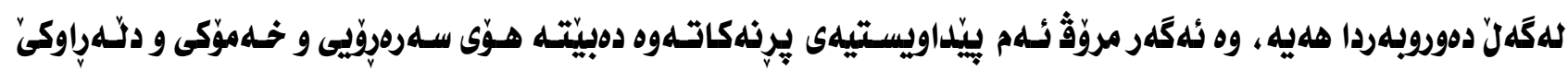
بووظى.

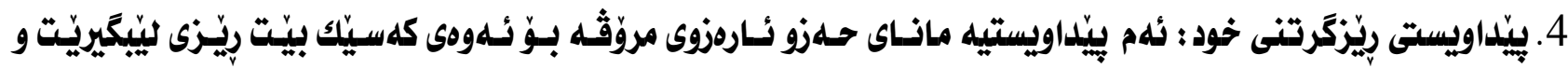

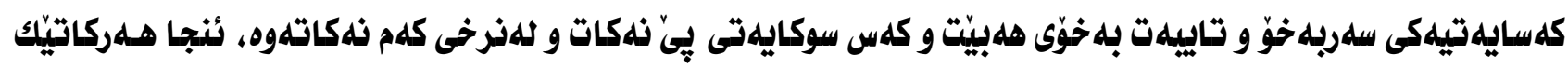

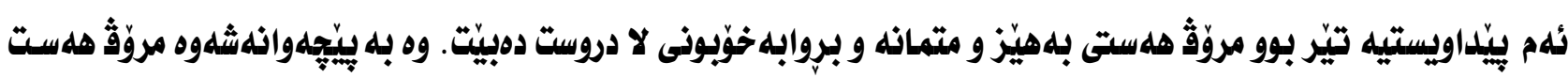

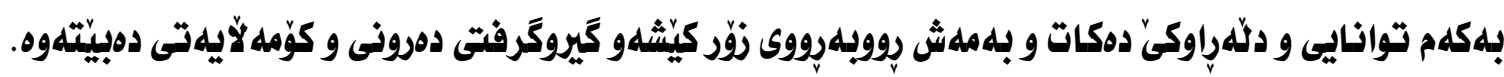

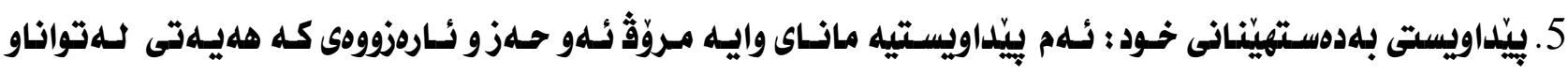

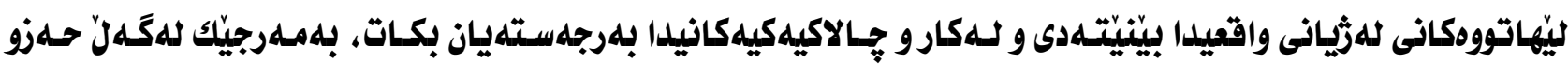
تُارهزو تواناكانيدا بكَو نجيّيت.

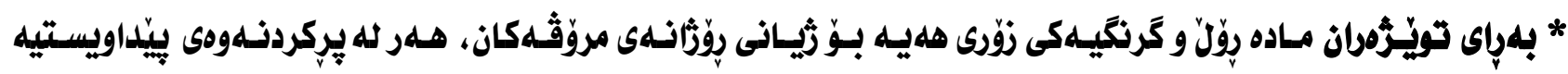

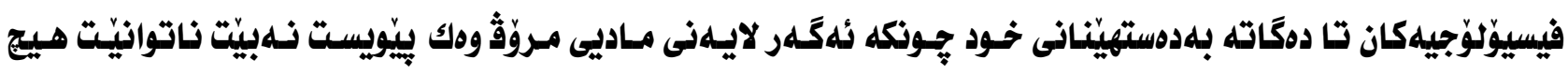

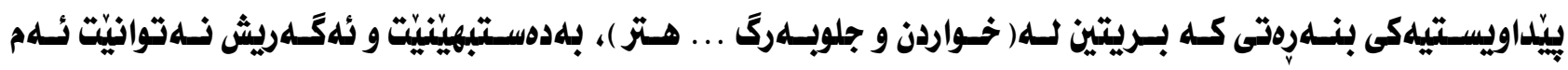

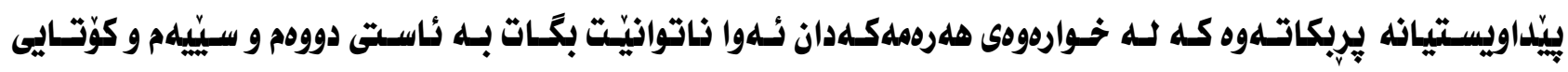

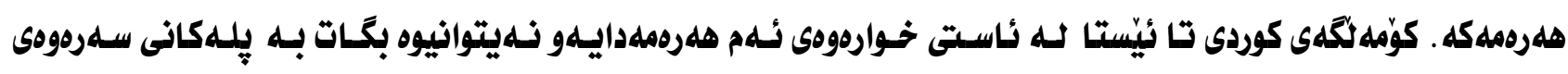
.

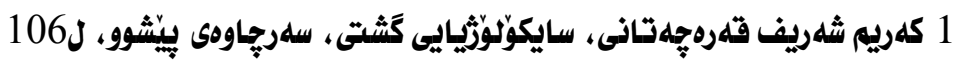


باسى دوومم/ قلهيرانى دارايق له كوردستان و جيكهوتهكانى يهكمم: تهيراذى دارايى له كوردستثاز

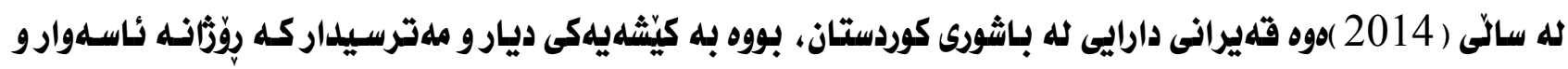

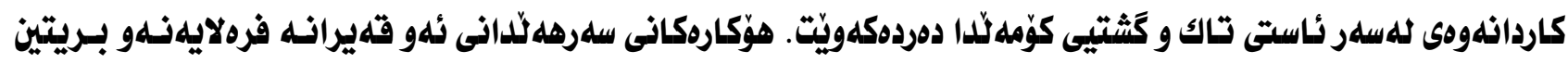

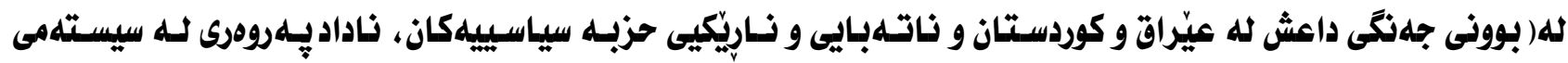

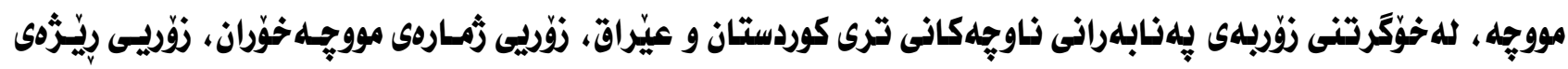

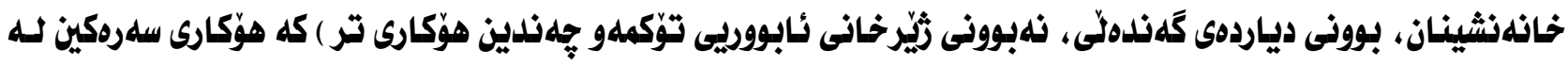

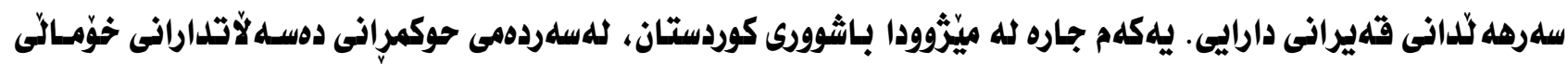

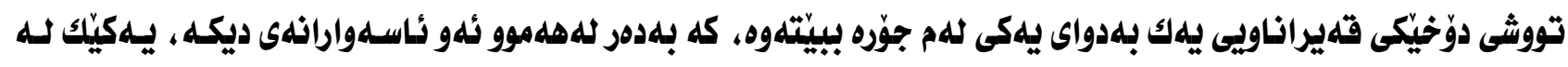
جياوازيى كاردانهودكانى تر بريتييه لله يـاشهكووتكردن و دواخستنى مووجهى سلرجهم فهرمانبهرانى كوردستان، كه زيـاد

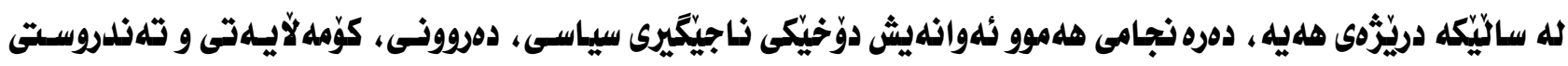

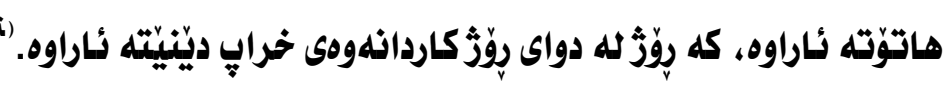

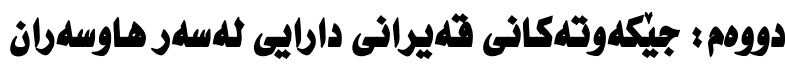

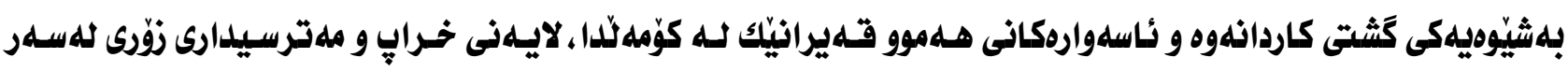

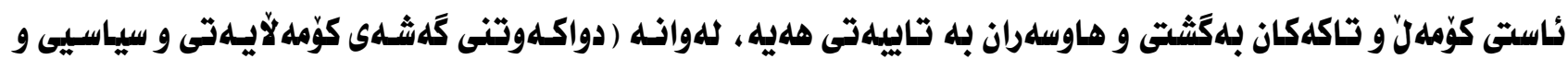

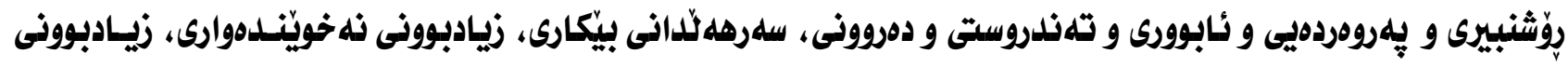

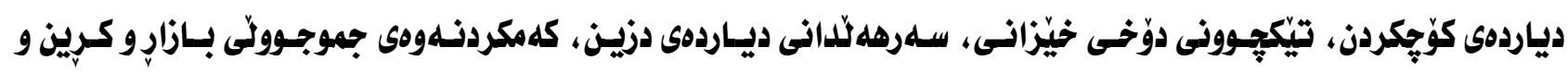

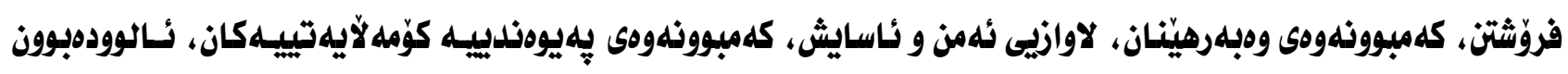

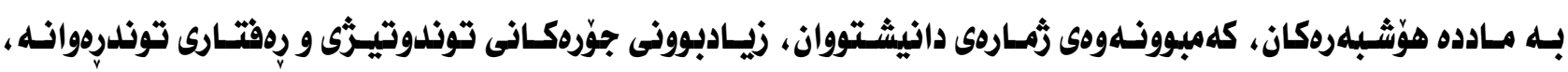

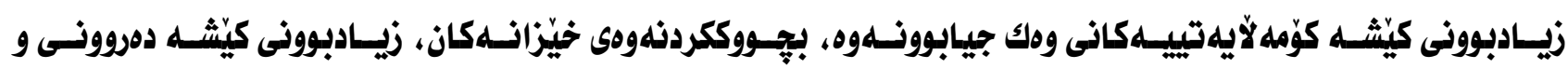

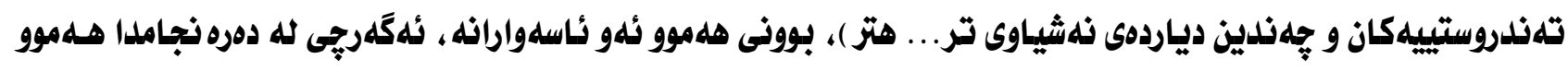

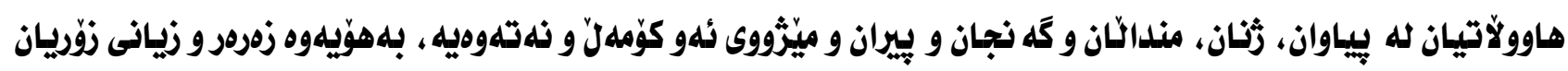

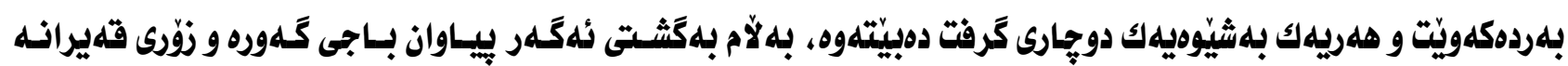

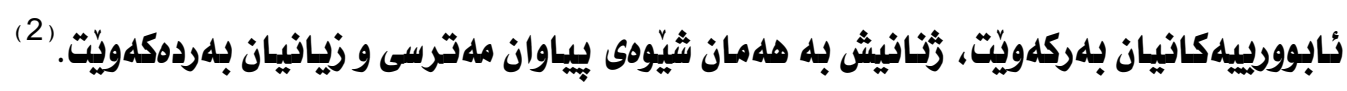

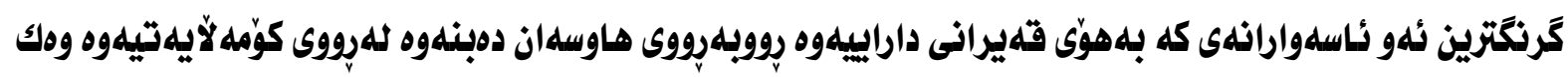

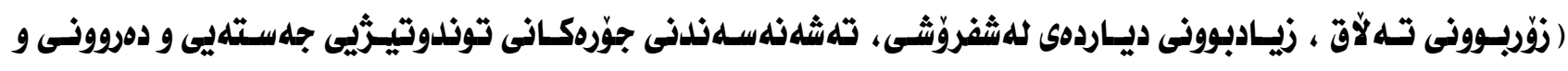

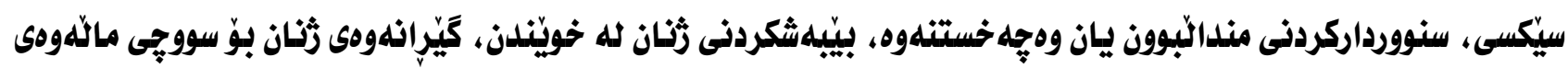

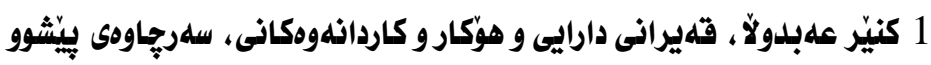

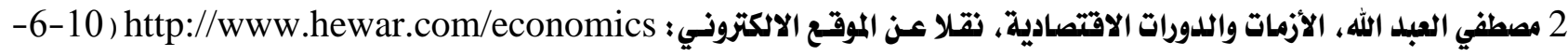




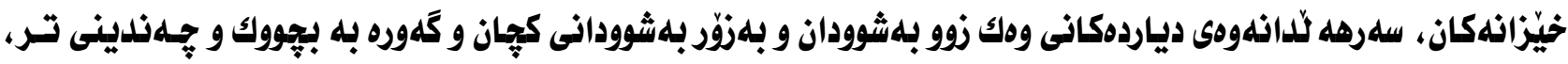

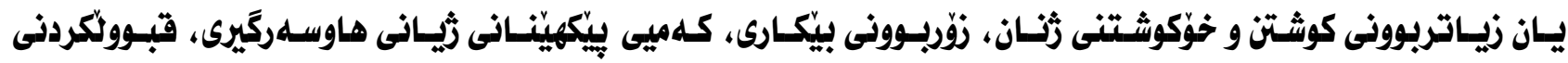

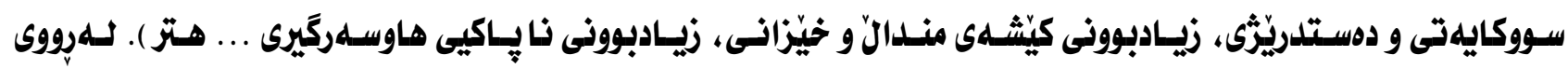

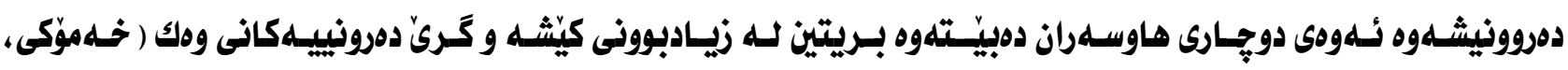

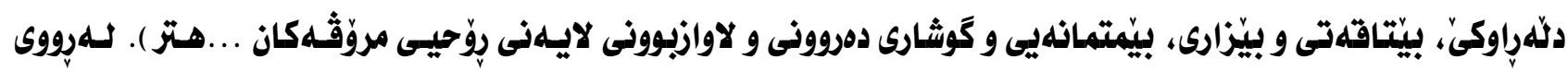

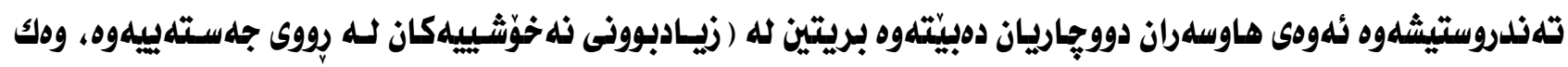

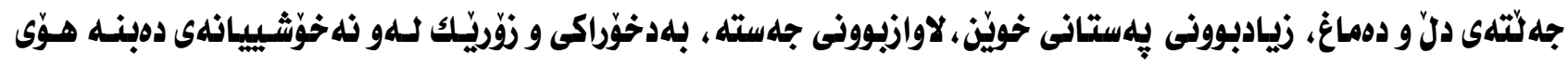

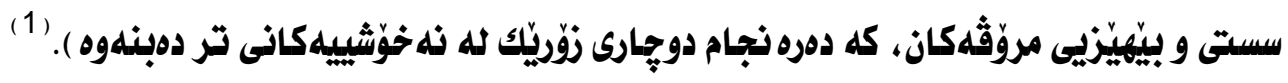

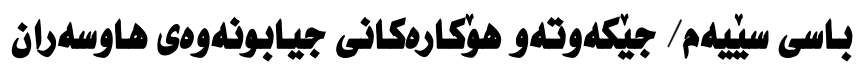

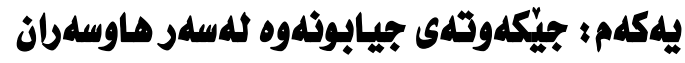

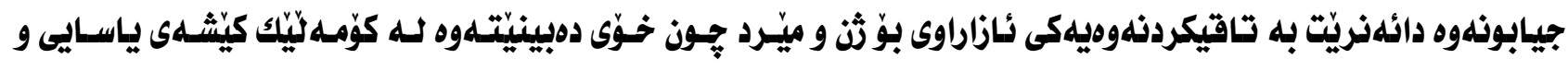

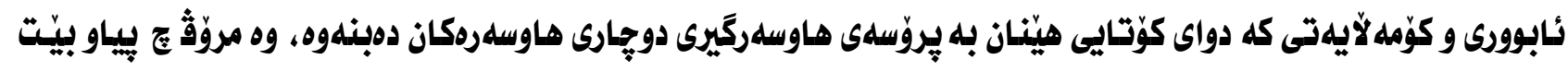

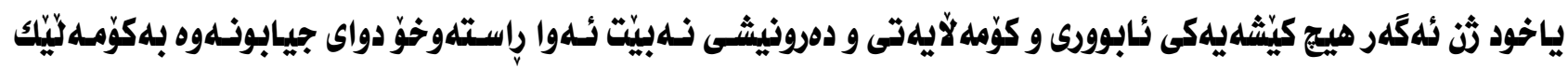

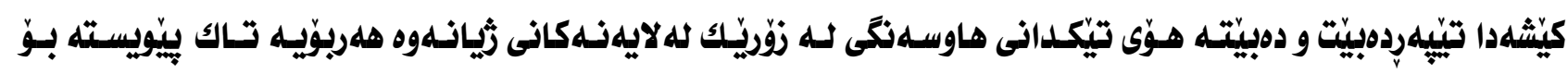

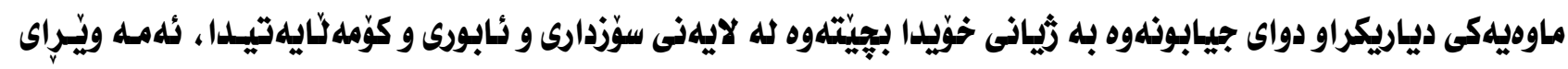

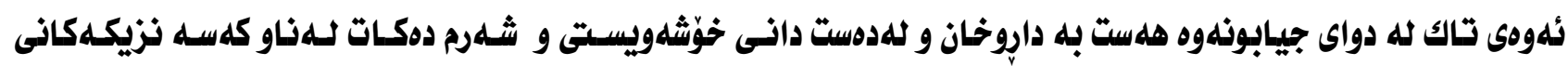

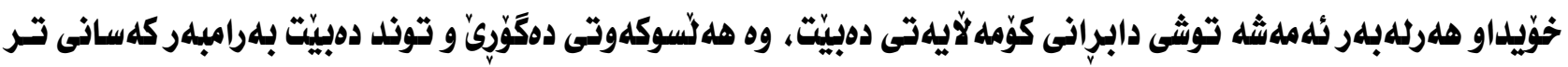

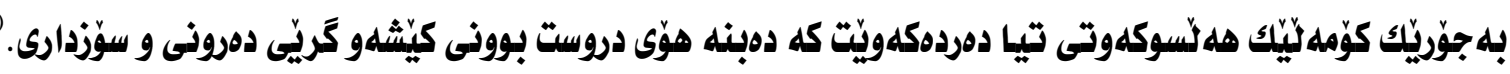

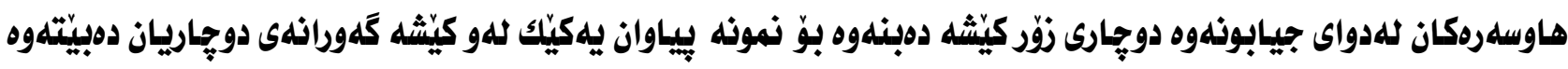

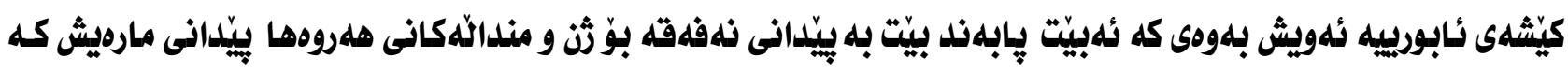

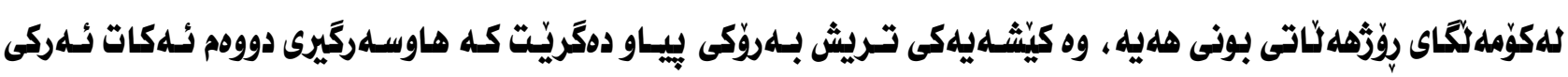

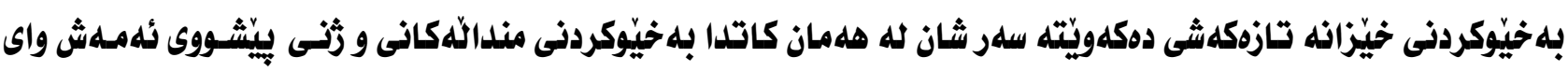

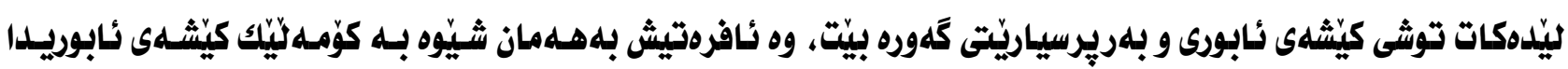

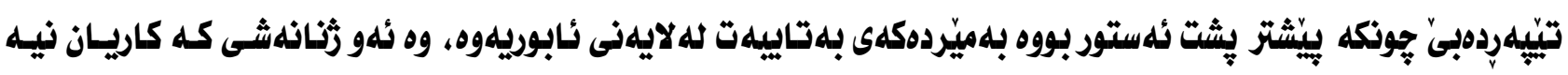

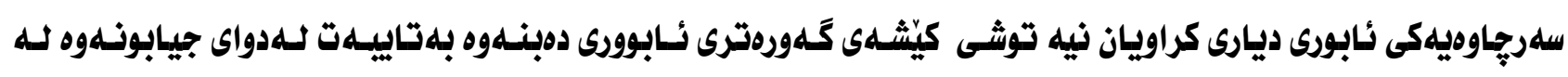

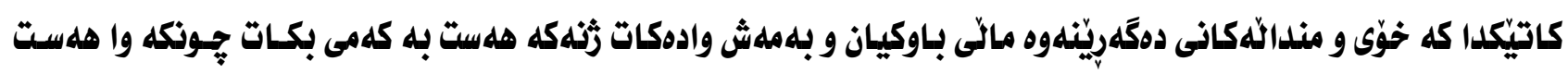

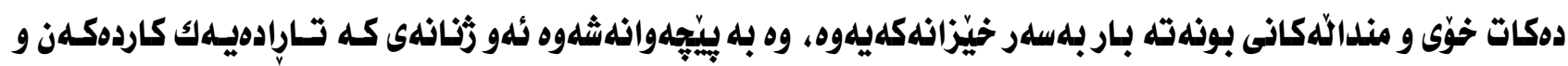

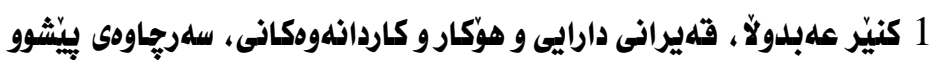

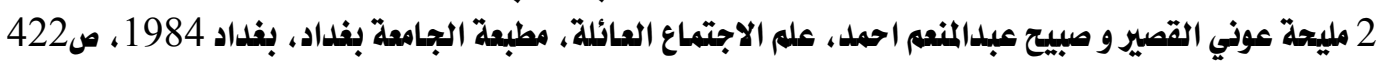
61 acadj@garmian.edu.krd

Vol.5, No.1 (May, 2018) 


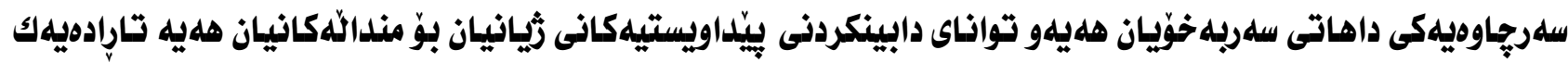

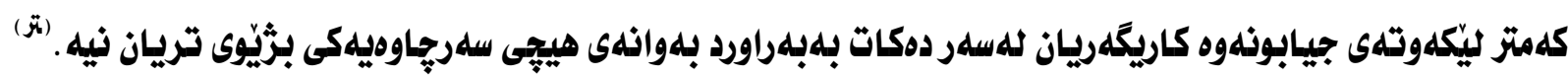

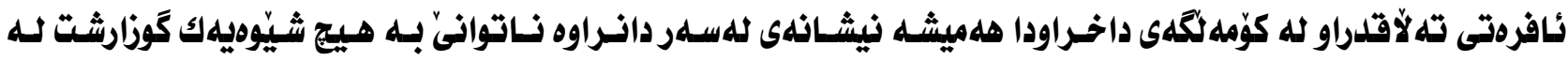

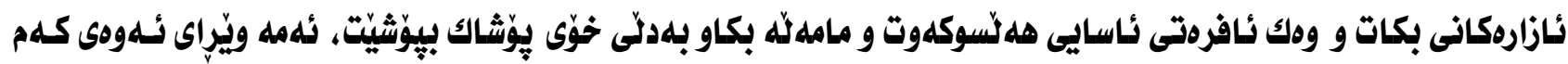

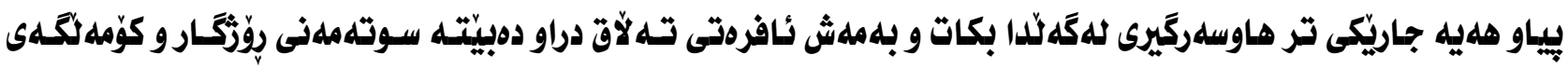
(ㄱ) بياوسالار.

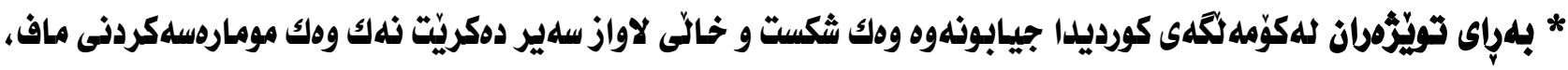

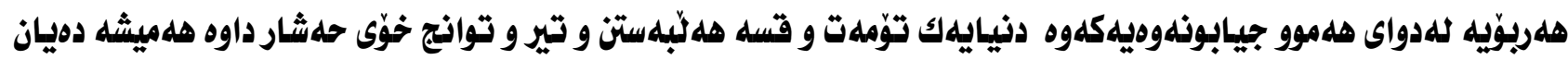

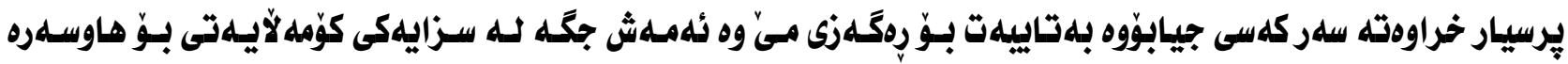
جيابِووكان هيج مانايلهى ترى نييه.

دووهم: هوكاروكانى جيابوخلهوه

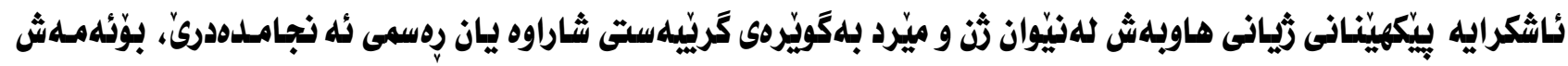

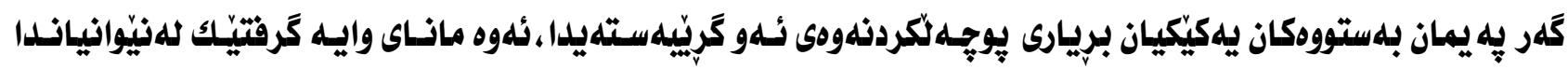

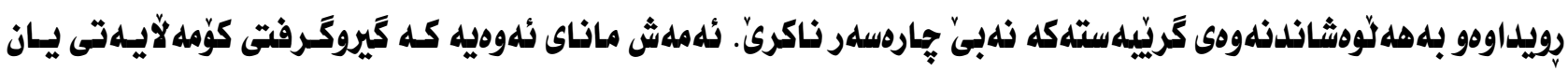

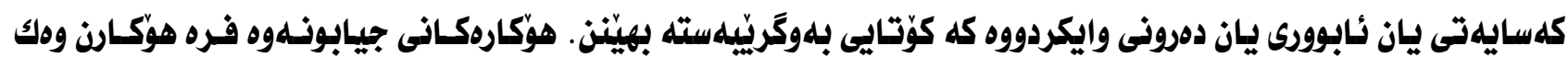

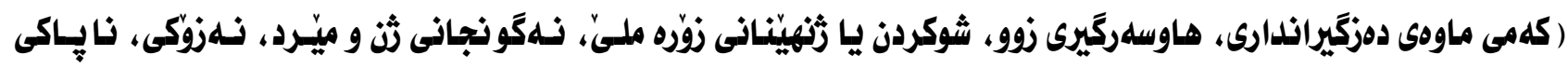

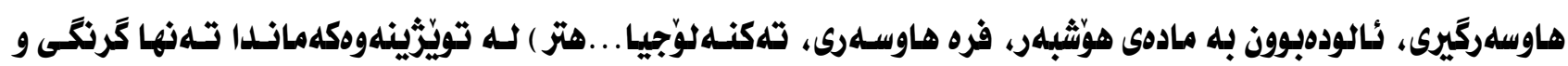

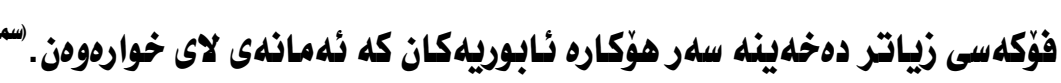

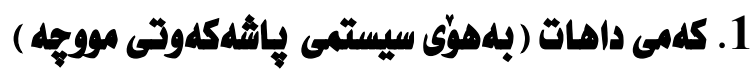

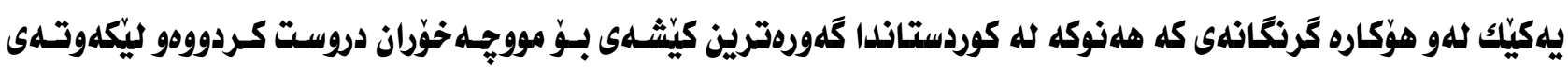

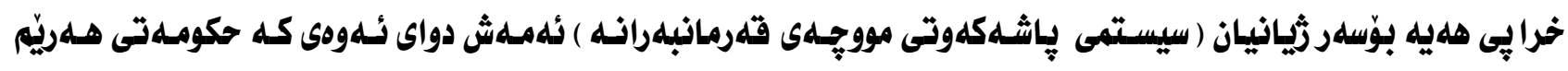

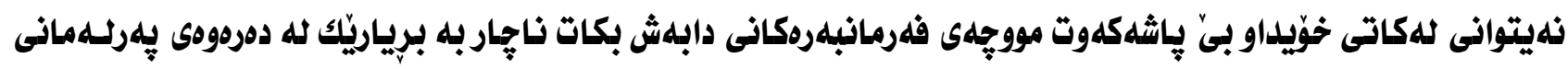

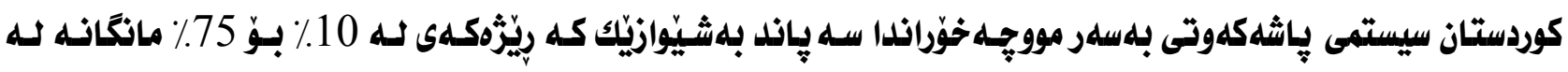

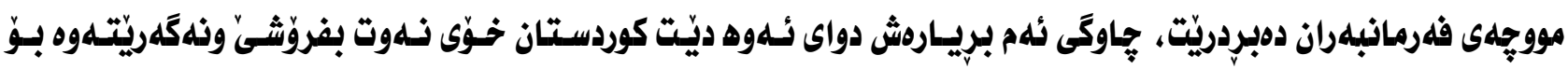

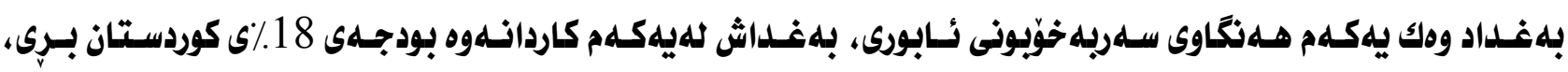

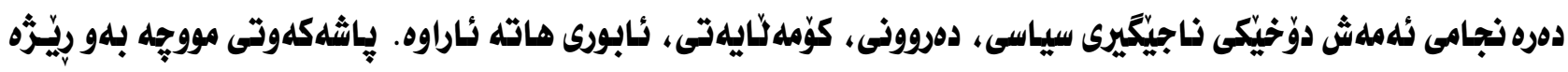

1 مليحة عوني القصير و صبيح عبدالمنعم احمد، علم الاجتماع العائلة، المصلدر السابق، ص433

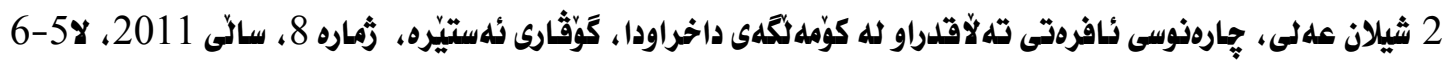

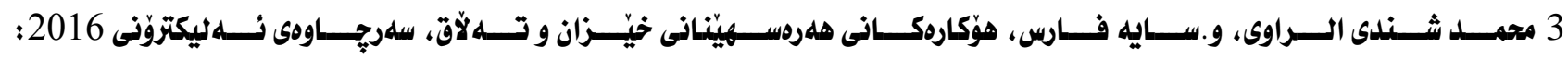
(2017-6-20 ) http://www.shanpress.com/details.aspx ?jimare=5813 62 acadj@garmian.edu.krd

Vol.5, No.1 (May, 2018) 


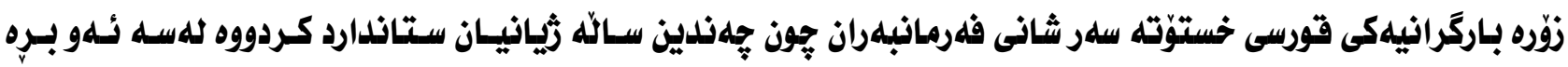

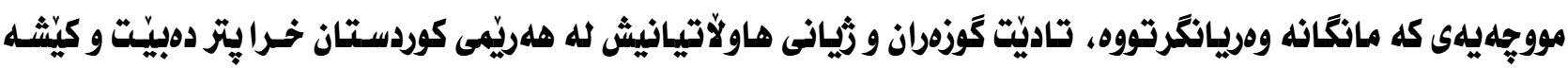

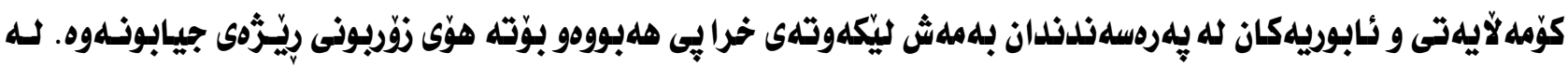

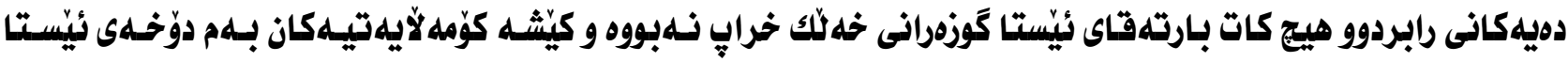

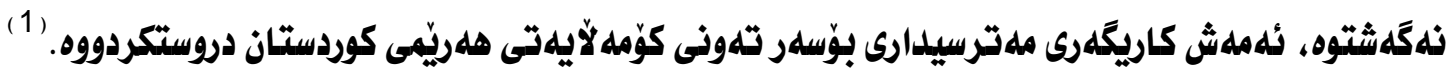

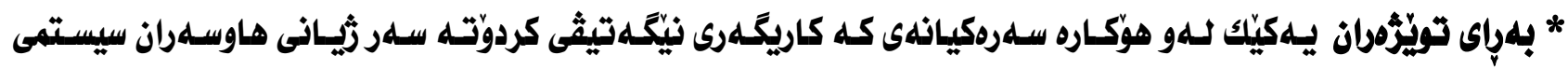

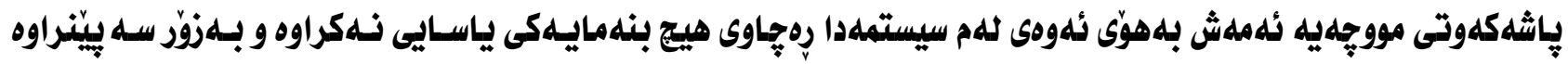

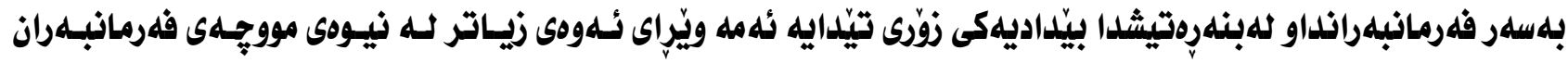

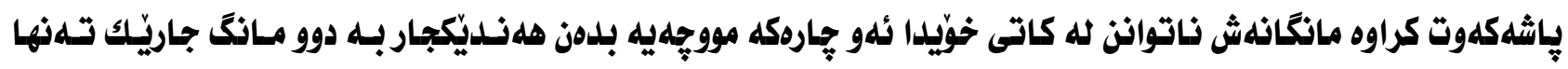

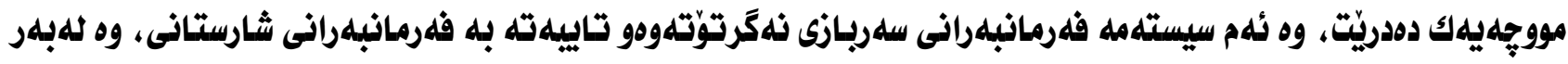

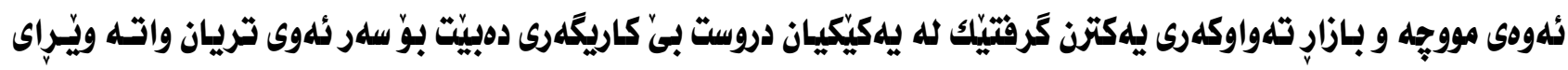

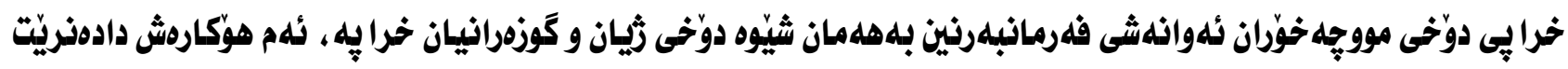

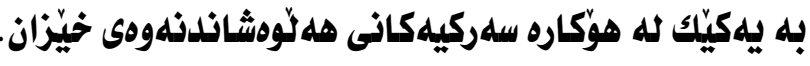

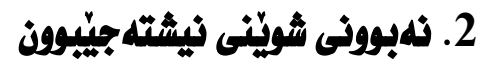

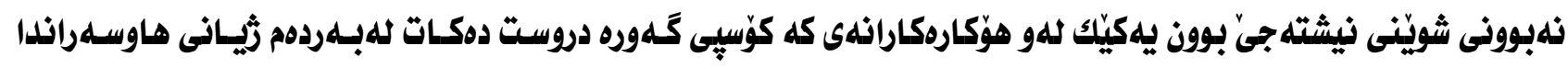

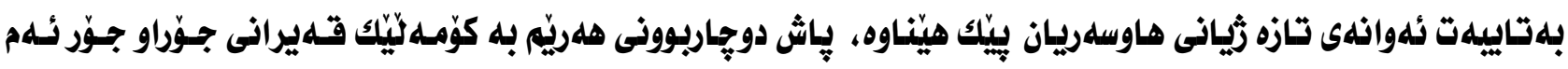

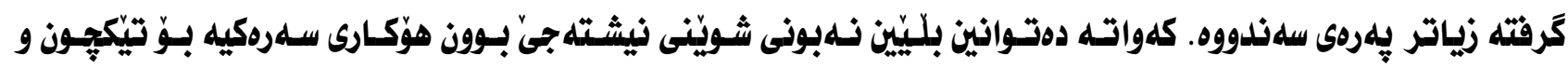

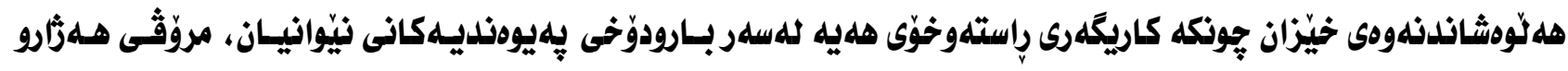

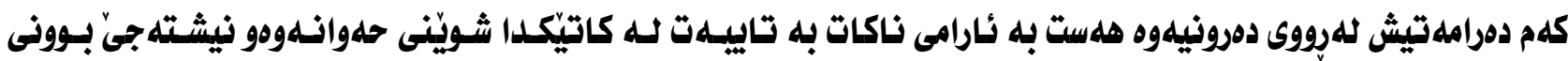
(ت) نهبيّت

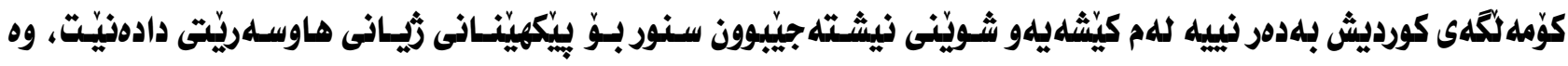

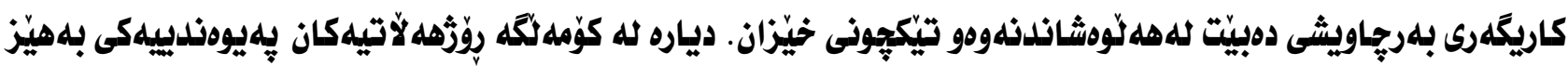

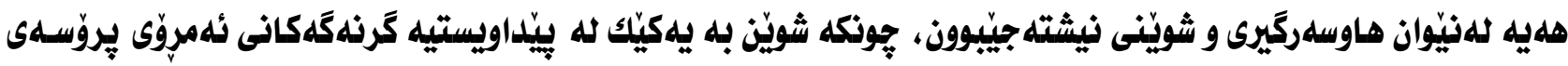

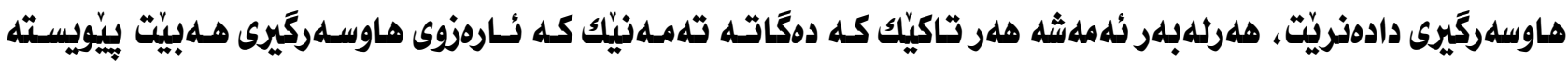

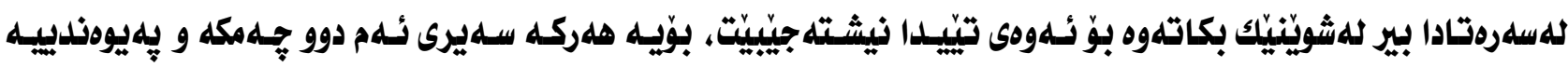

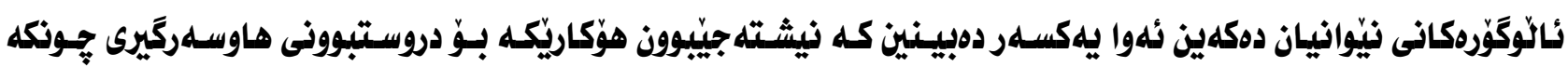




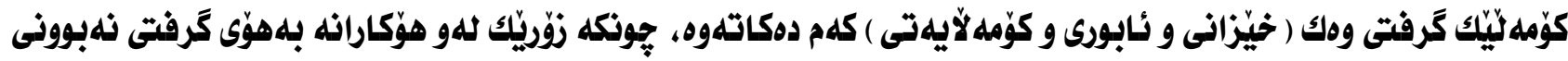
شويّنى نيشته جئ بوونلهوه دروست دهبن.

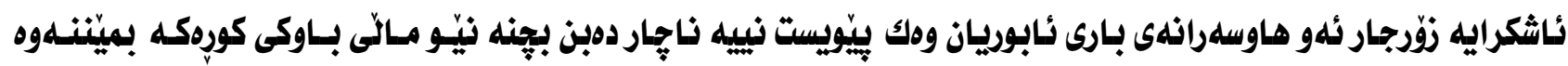

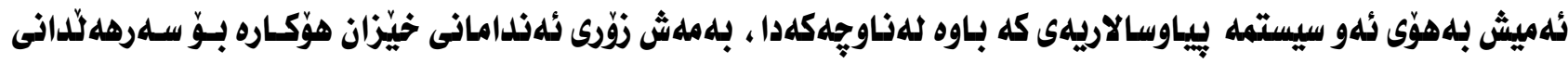

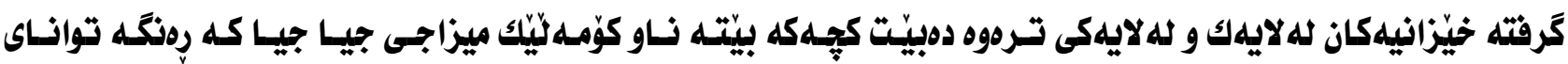

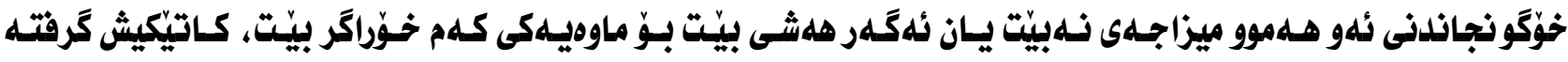

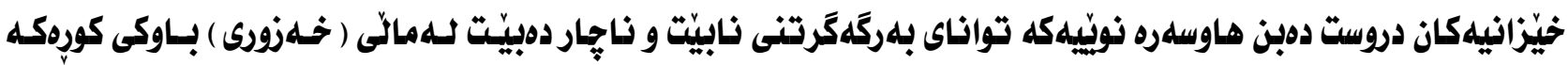

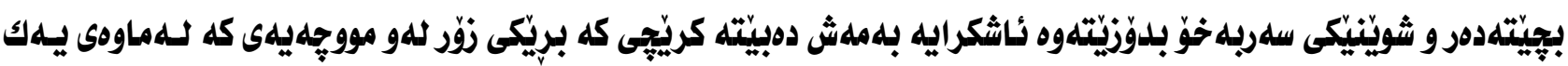

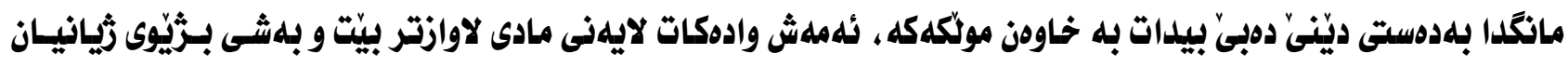

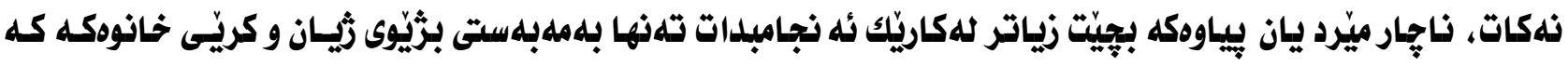

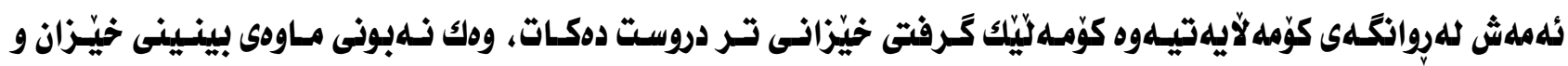

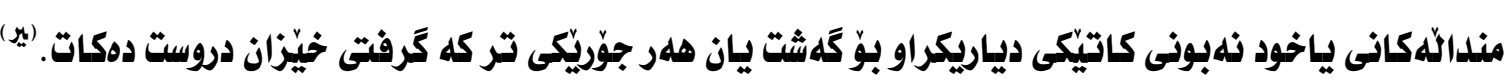

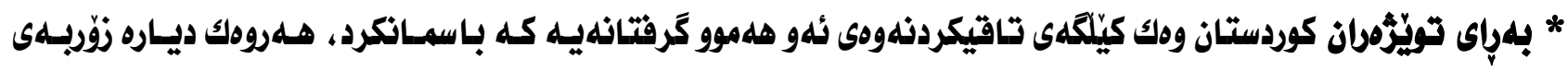

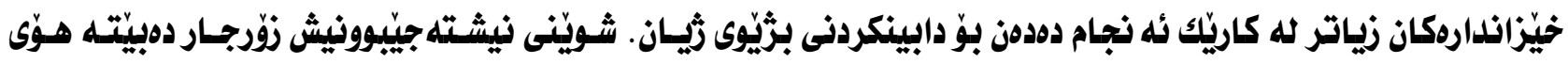

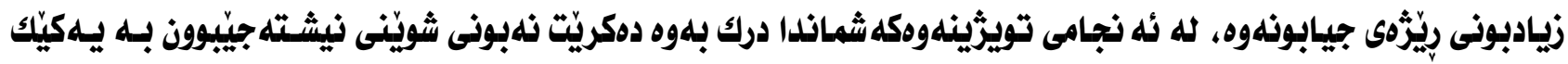

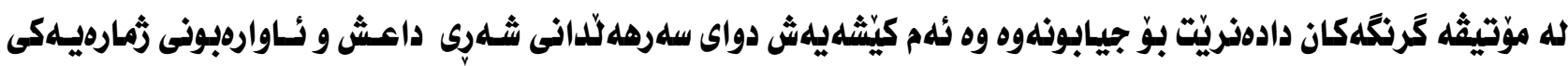

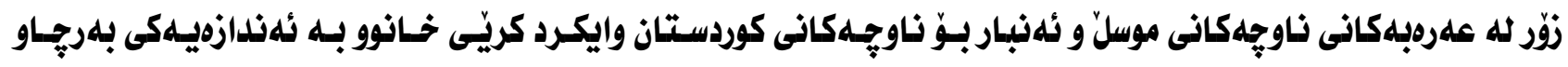

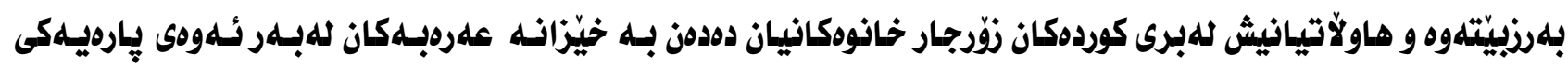
زيـاتريان دهدهذى به بهراورد به خيّزانه كوردوكان.

$\cos \operatorname{tas}^{*} .3$

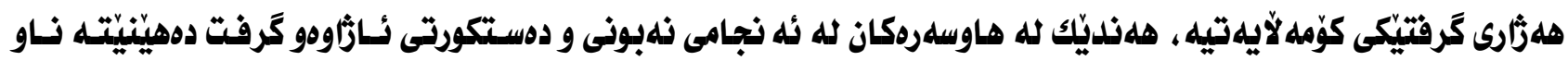

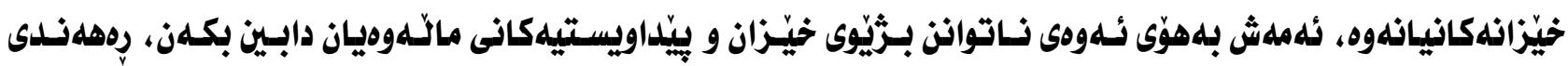

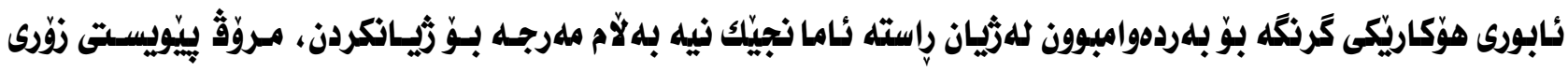

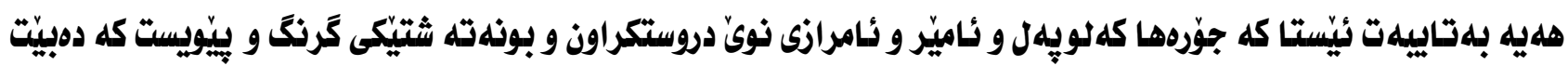

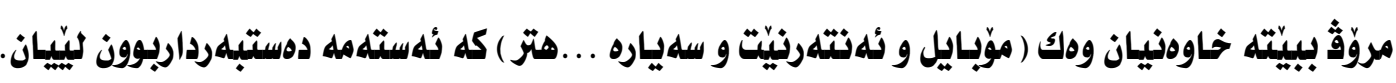

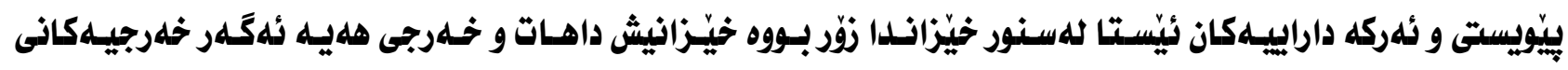

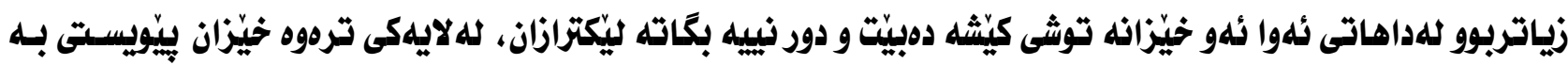

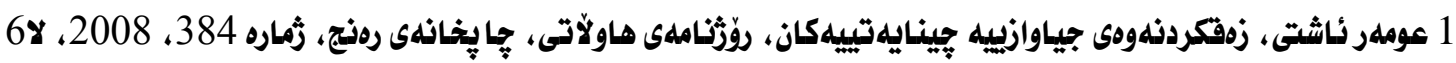

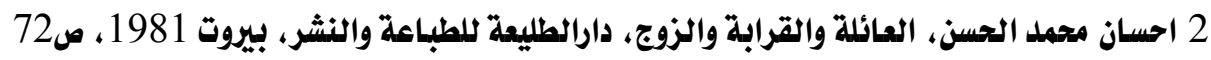

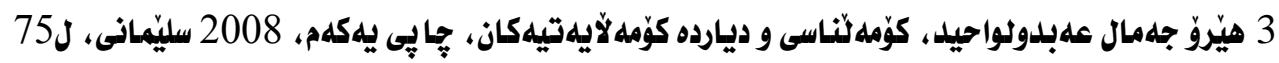




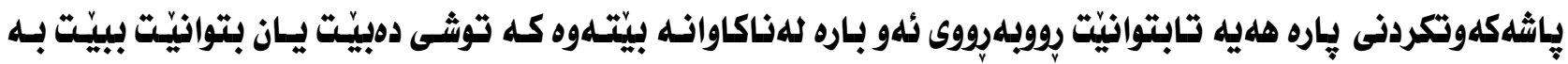

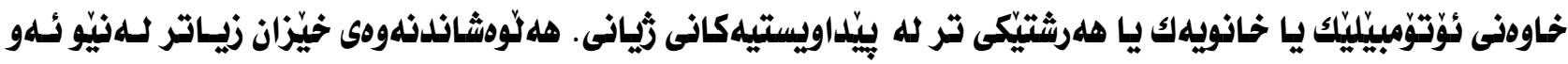

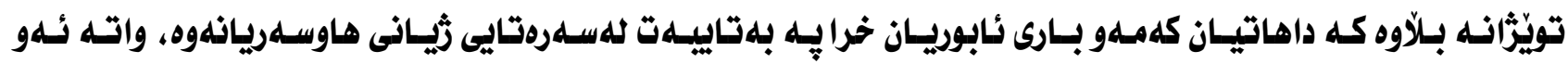

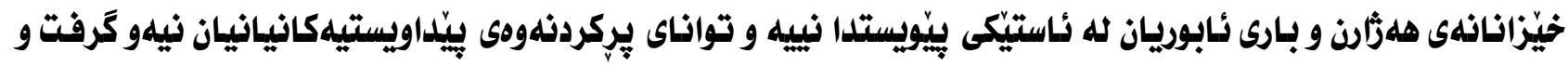

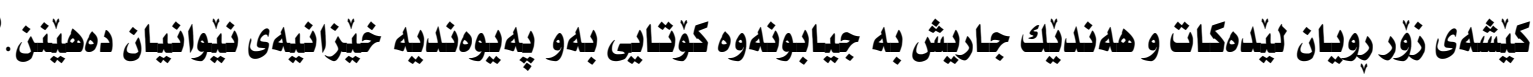

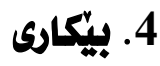

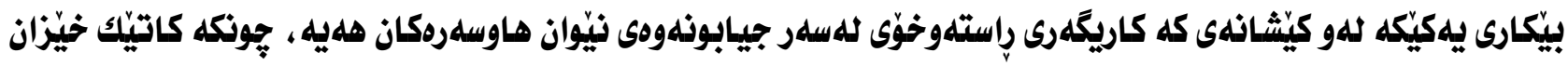

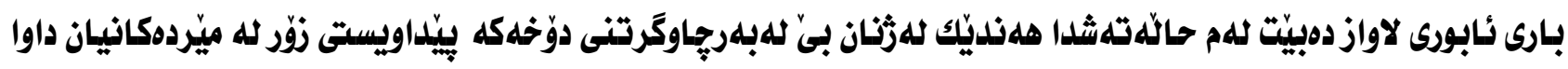

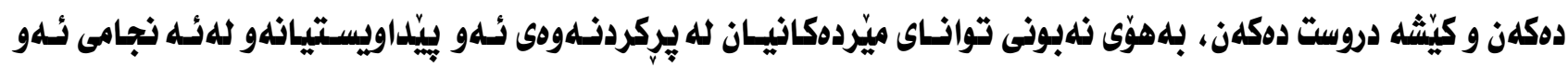

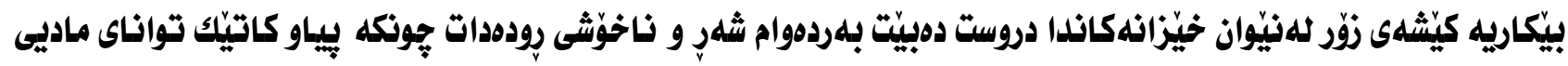

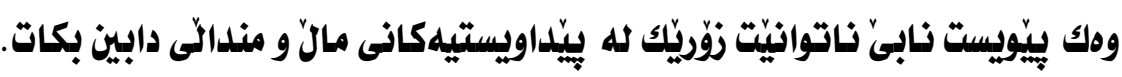

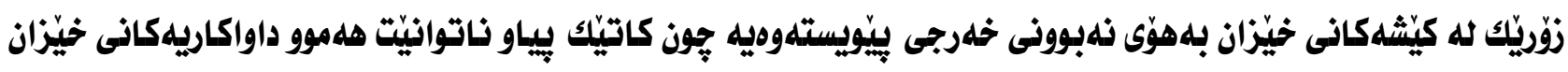

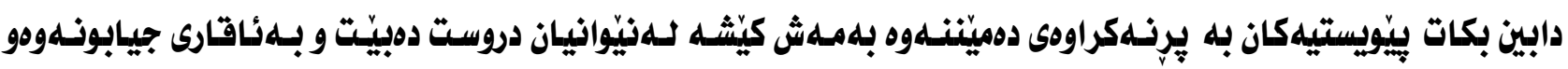

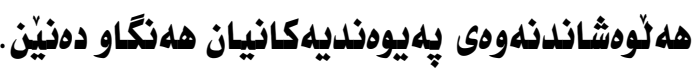

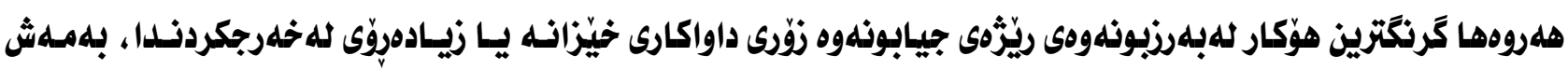

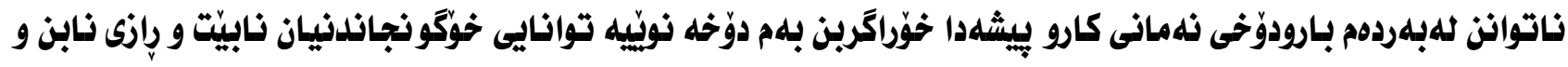

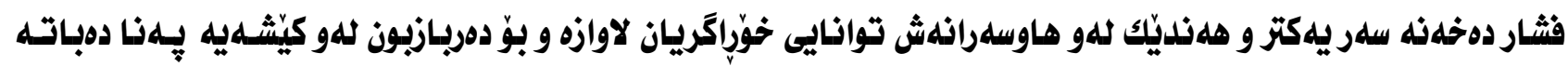

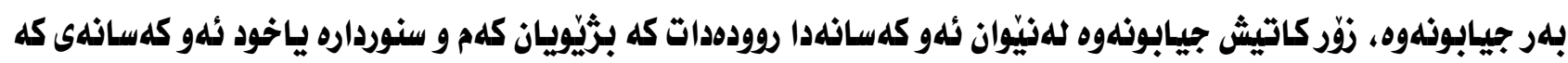
خاوهنى كارى جيّكير نين للهزياندا.

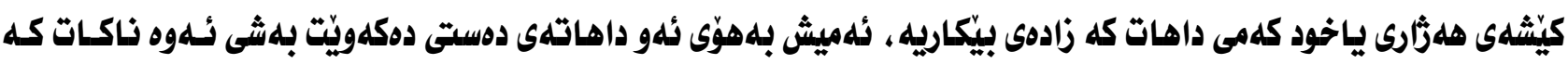

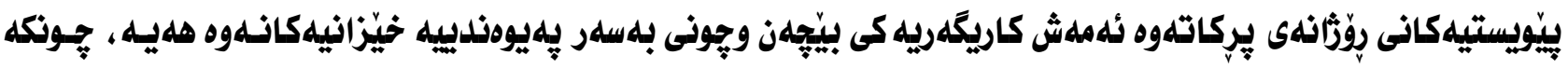

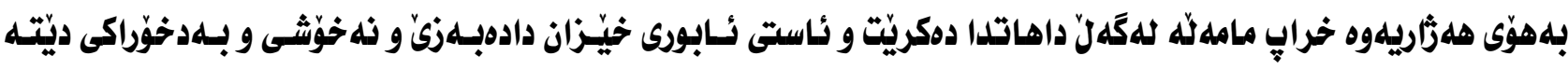

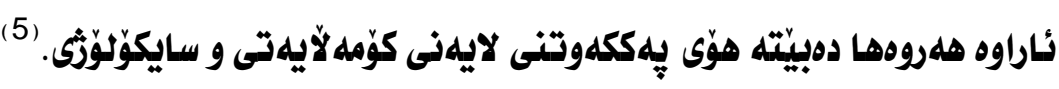

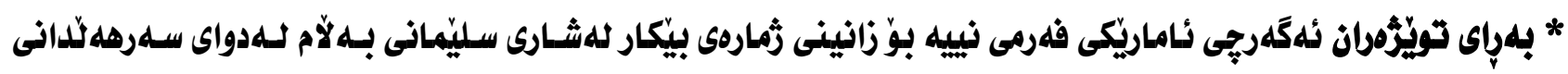

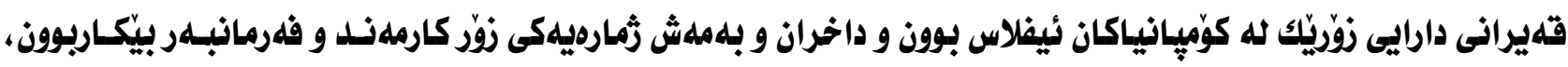

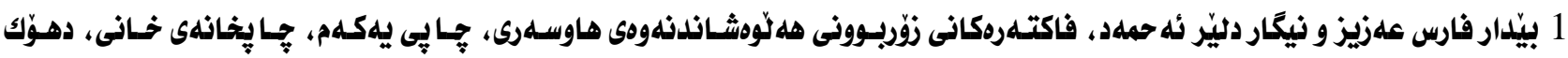

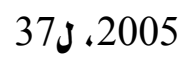

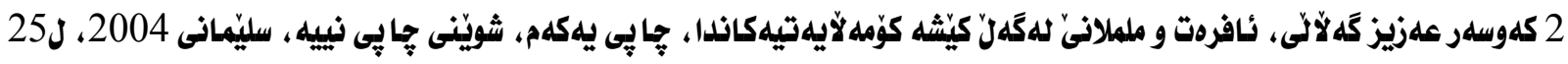

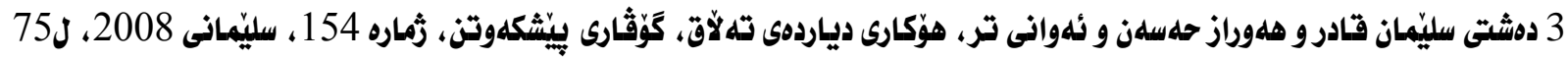

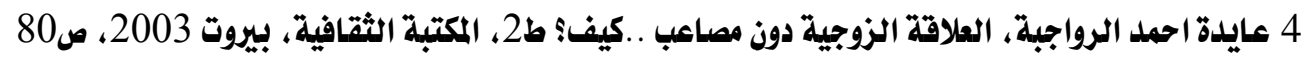

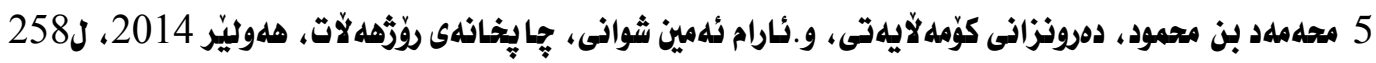




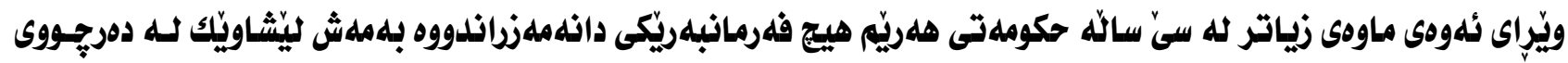

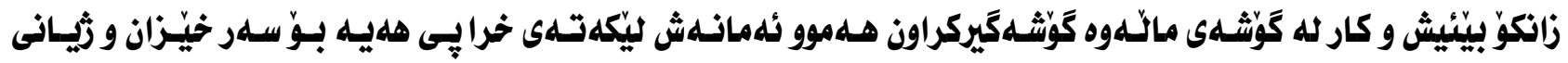

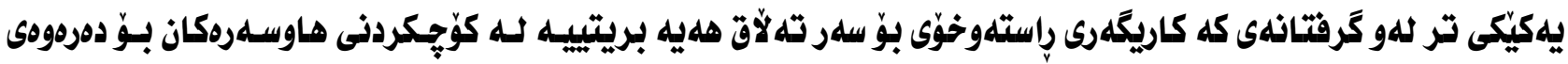

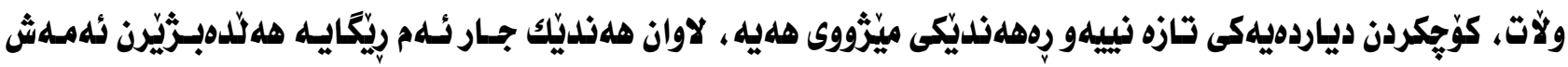

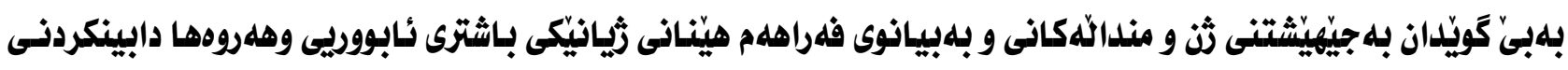

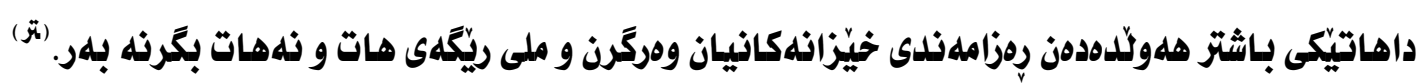

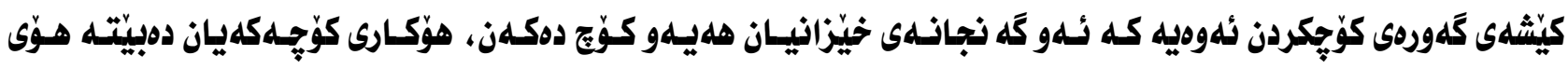

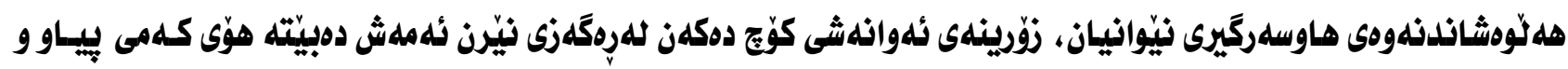

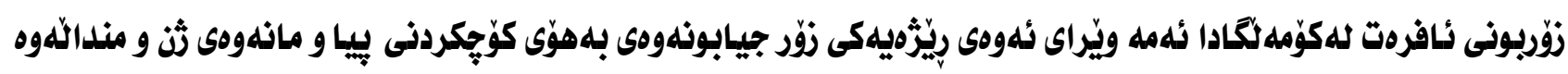

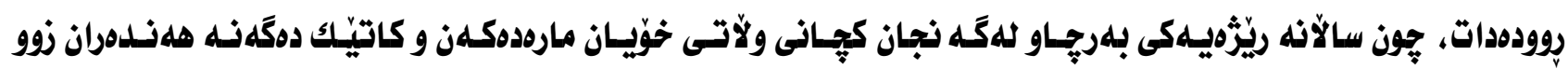

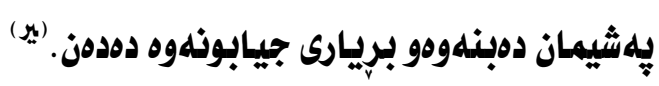

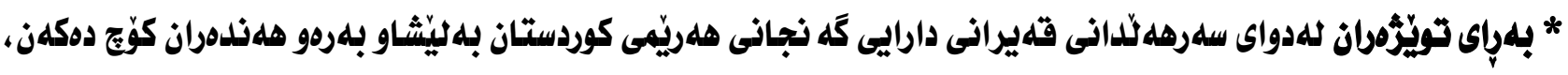

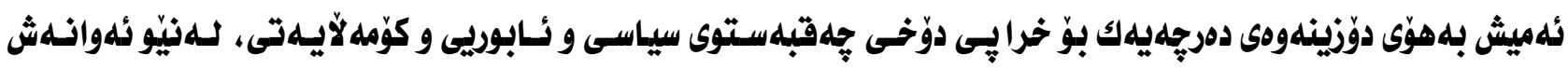

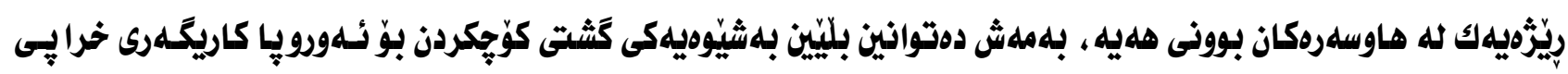

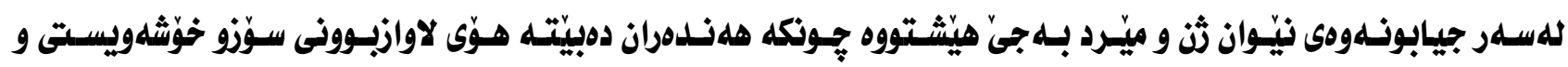

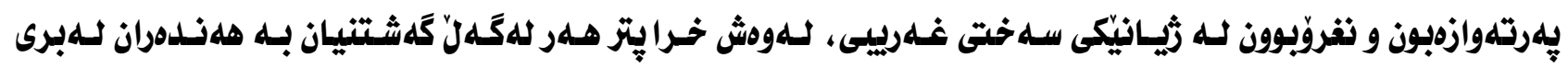

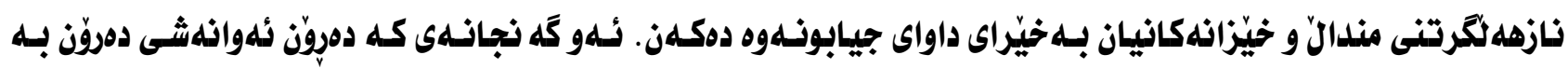

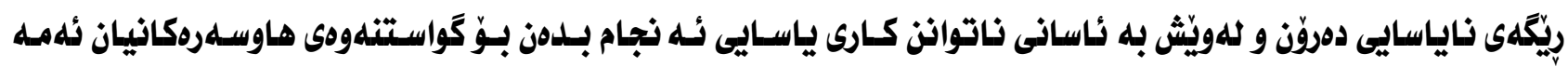

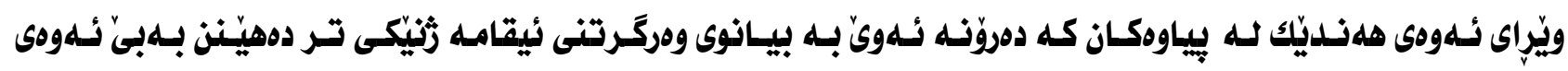

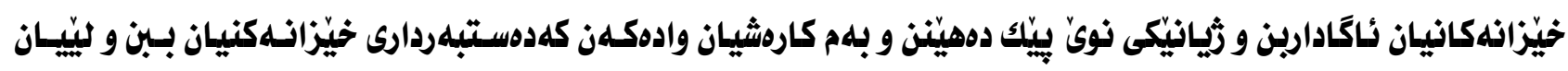

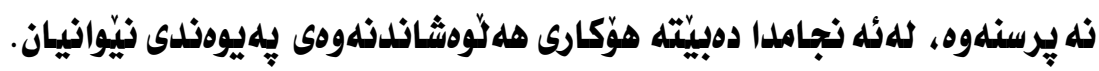

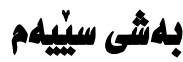

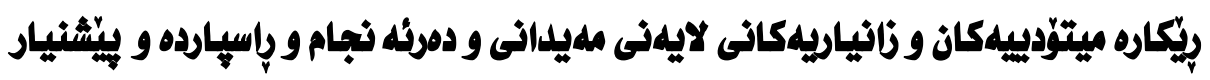

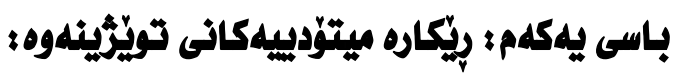

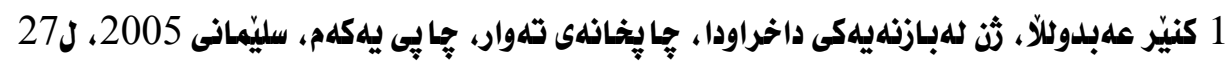

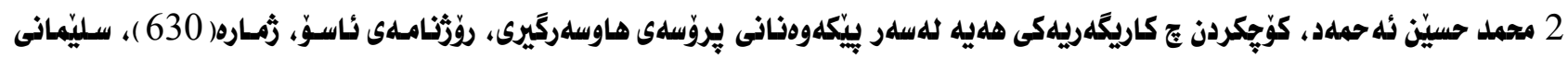




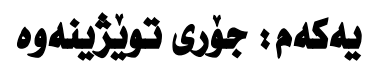

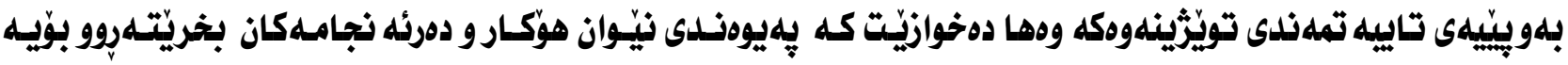

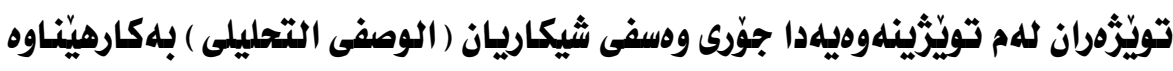

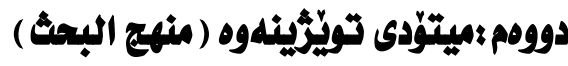

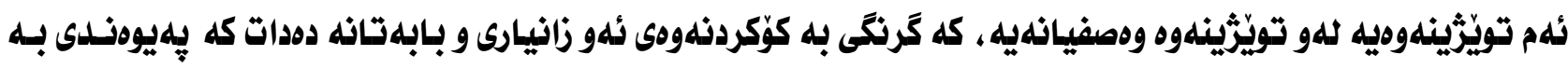

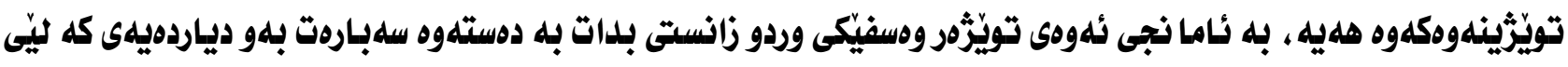

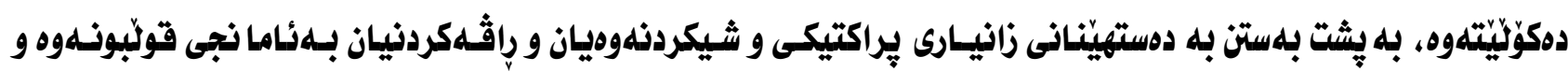

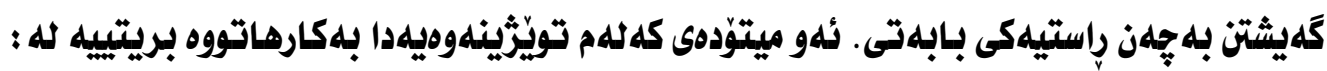

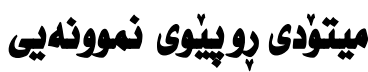

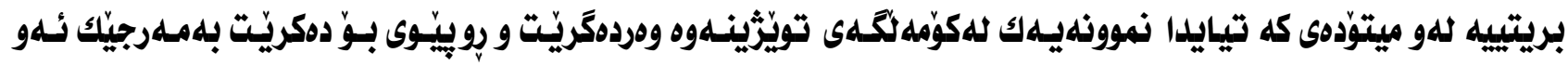

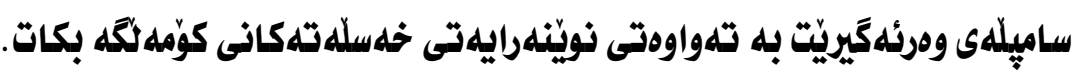

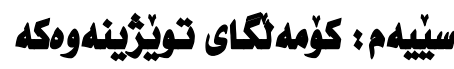

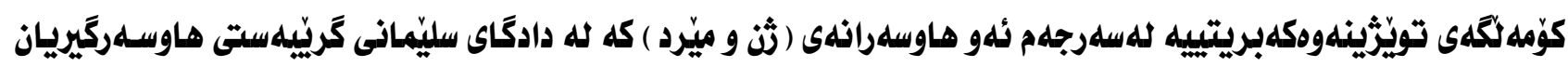

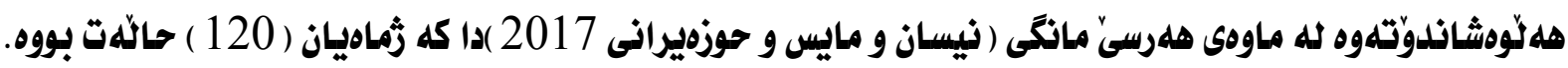

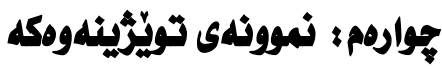

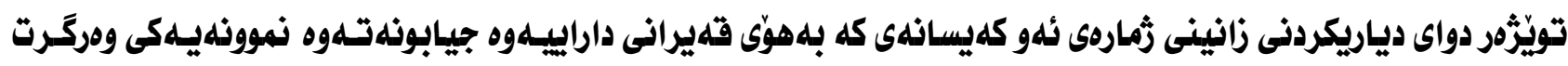

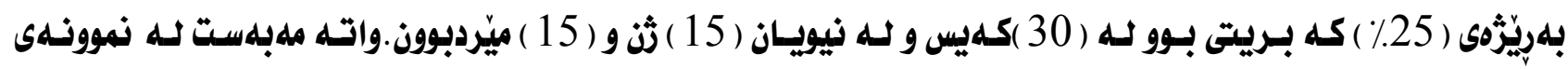

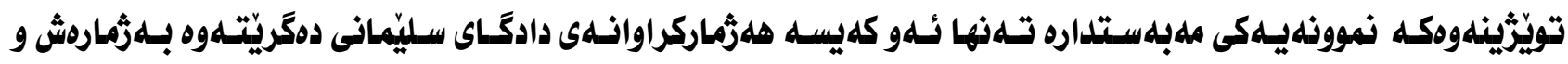

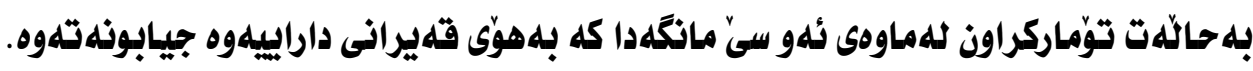

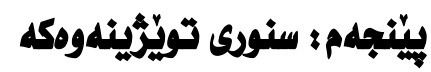

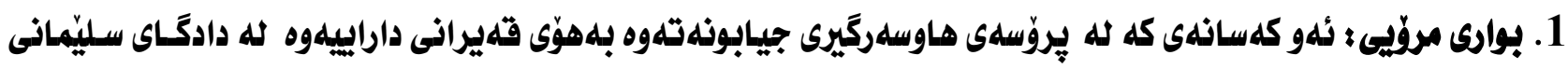
تُوْماركراوز. 2. بوارى شُويّنى : تهنها شارى سليّمانى ( مركز المدينه )لايهنى مهيدانى تويّزينهودكه بووه.

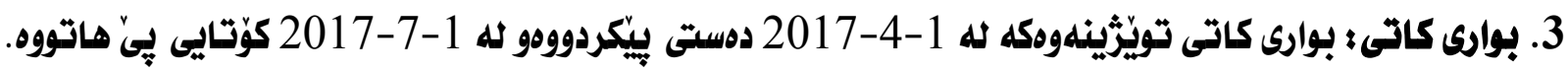

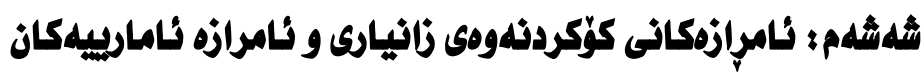

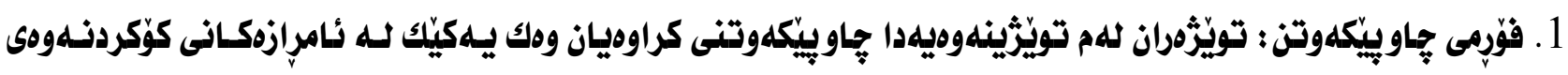

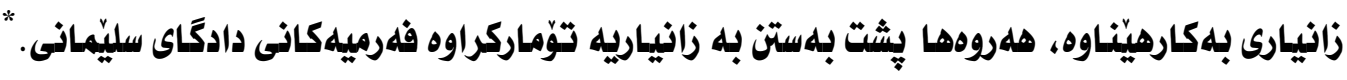

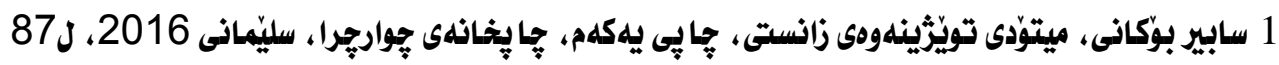

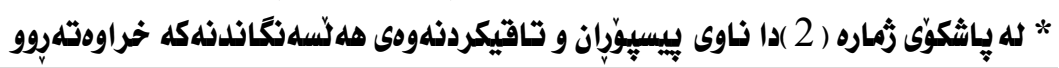




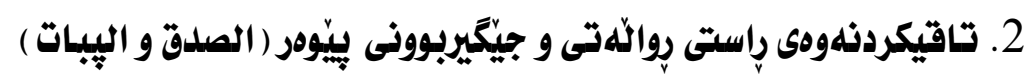

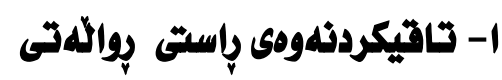

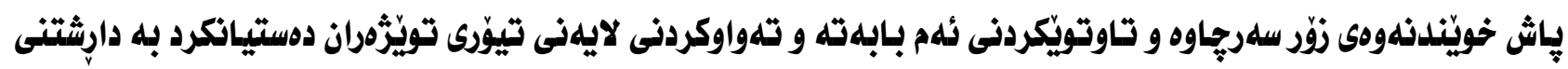

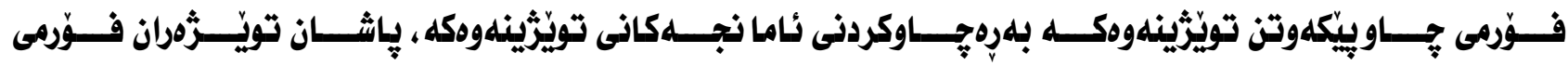

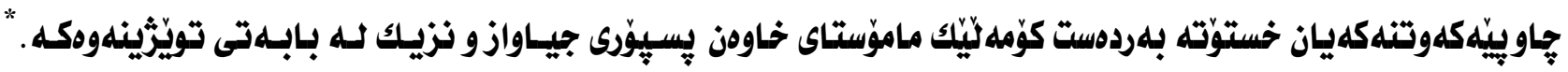

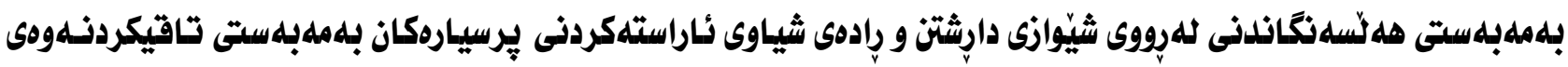

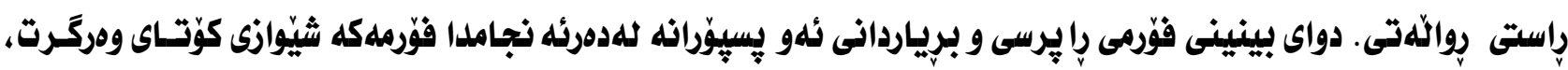

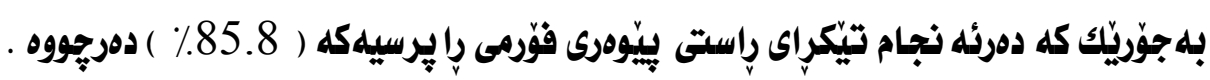

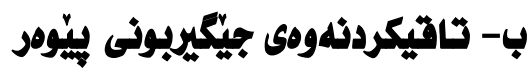

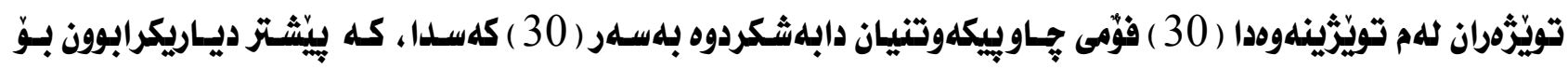

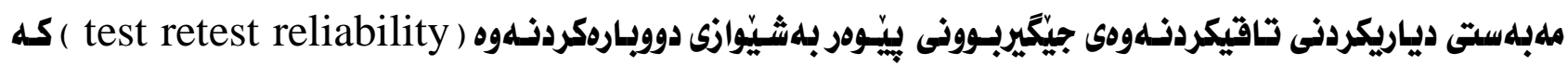

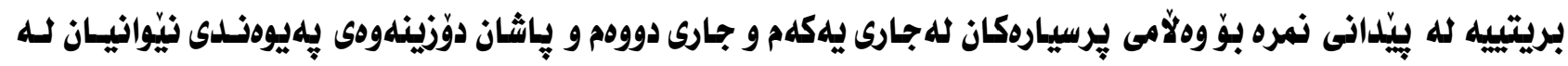

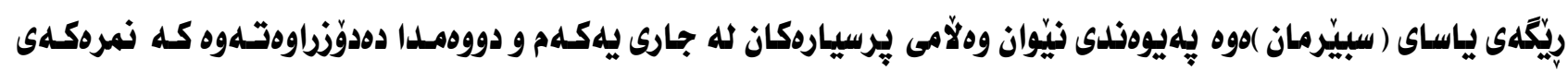

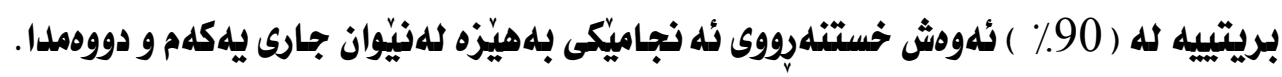

3. تُمرازه نُاماريهكان

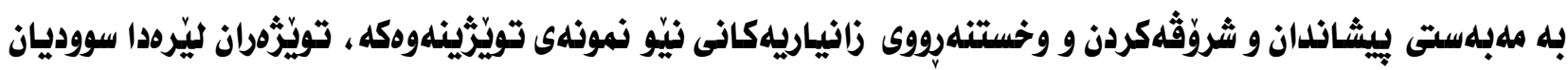

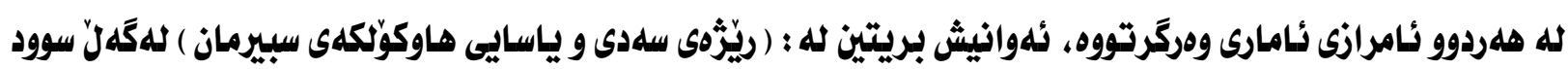

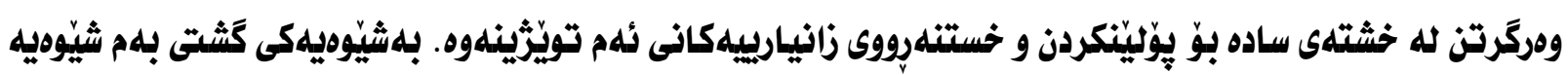
ده يخذهينهروو :

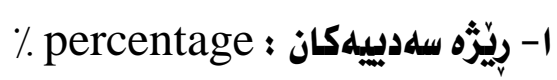

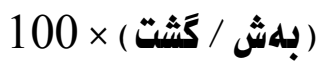

ب- جيّبه جيّكردنى ياسايى هاوكوّلكهى ( سيبرمان ) = 6 مجـ ر2 ف

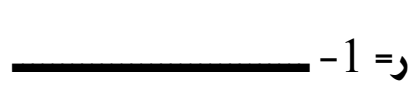

j

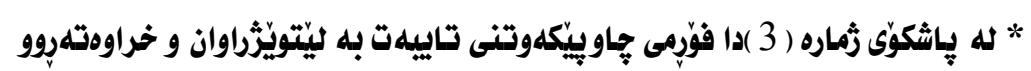




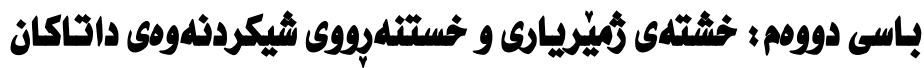

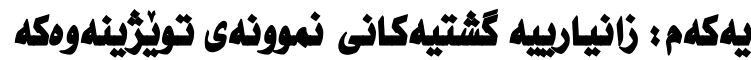

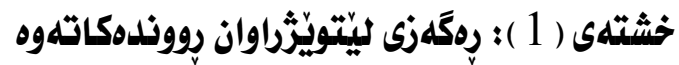

\begin{tabular}{|c|c|c|}
\hline ريّزَّى سلهد ٪ & دووبـارهبوودكان & رهذَز \\
\hline$\% 50$ & 15 & نيّر \\
\hline$\% 50$ & 15 & مى" \\
\hline$\% 100$ & 30 & كؤى كَثتتى \\
\hline
\end{tabular}

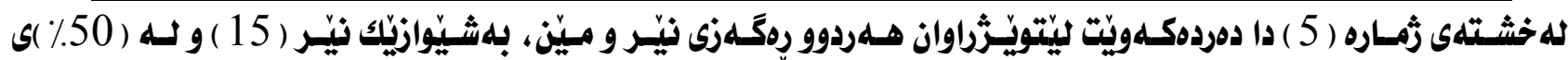

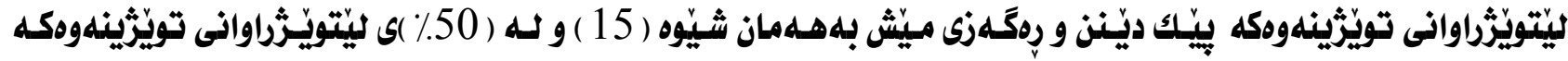

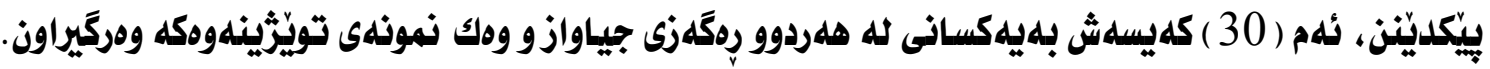

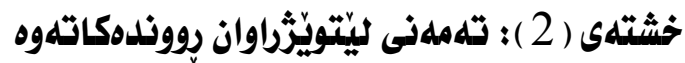

\begin{tabular}{|c|c|c|}
\hline ريّزَّهى سلهد ٪ & دووبـارهبوهكان & تهمله \\
\hline$\% 40$ & 12 & $30-26$ \\
\hline$\% 30$ & 9 & $35-31$ \\
\hline$\% 30$ & 9 & $40-36$ \\
\hline$\% 0$ & 0 & $45-41$ \\
\hline$\% 100$ & 30 & كوّى كَشتى \\
\hline
\end{tabular}

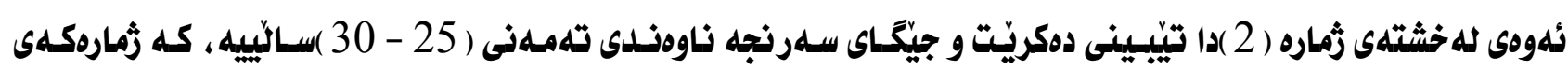

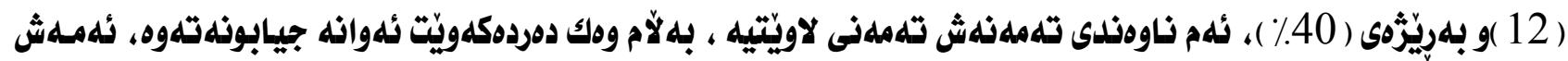

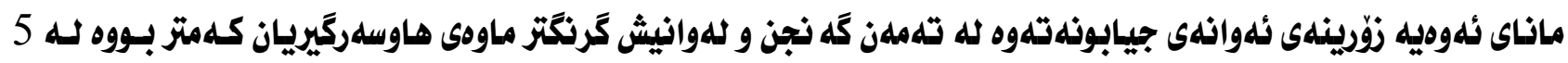

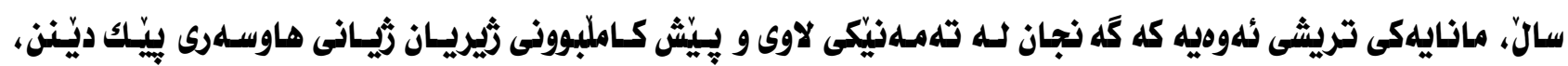

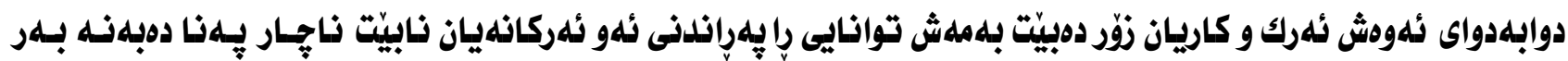

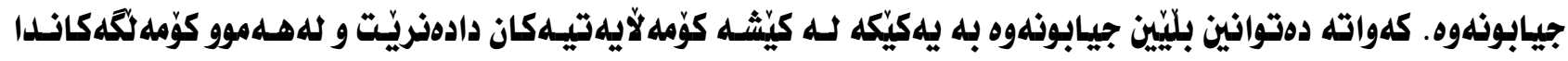
بونى هليه و هلموو تهمهناكانيش دمكريّتهوه و تاييهت نييه بله تهمهنيكى ديارى كراو.

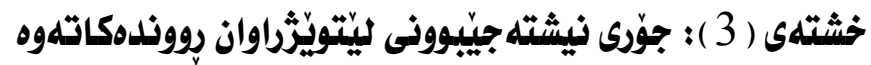

\begin{tabular}{|c|c|c|}
\hline ريّرَّى سلدي \% & دووبارهبووهكان & جوُرى نيشته جيِبوون \\
\hline$\% 10$ & 3 & مولَك ( خانووى خوّى ) \\
\hline$\% 40$ & 12 & كريِيِْى \\
\hline$\% 50$ & 15 & مايلّلباوان \\
\hline$\% 100$ & 30 & كوّى كَثتى \\
\hline
\end{tabular}




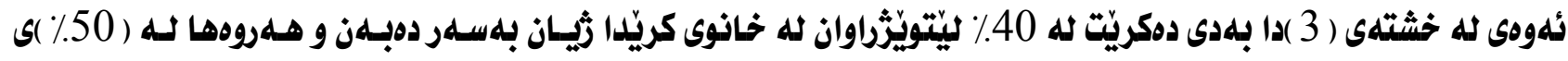

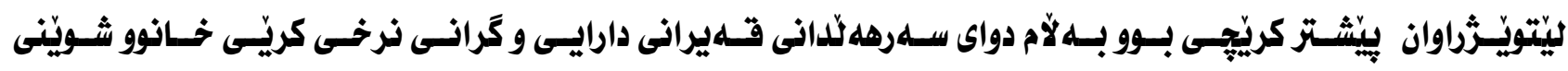

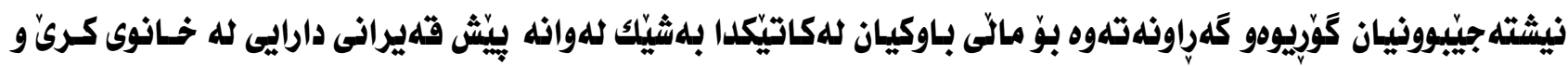

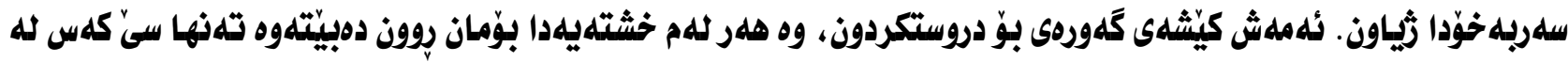

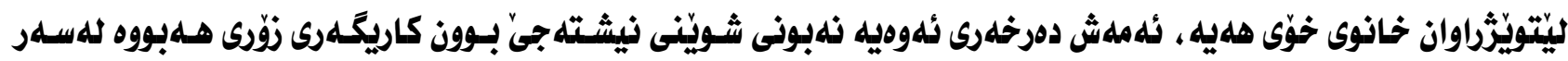
جيابونهوهى هاوسلهران.

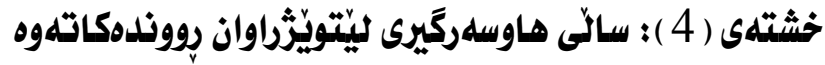

\begin{tabular}{|c|c|c|}
\hline ريّزّهى سلهدى \% & دوبارهبووهكان & سالّى هاوسلهركَيرى \\
\hline$\% 20$ & 6 & $2009-2006$ \\
\hline$\% 40$ & 12 & $2013-2010$ \\
\hline$\% 40$ & 12 & $2017-2014$ \\
\hline$\% 100$ & 30 & كوّى كَشتى \\
\hline
\end{tabular}

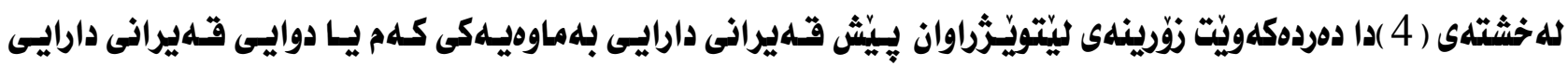

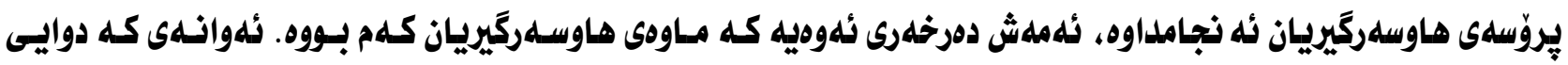

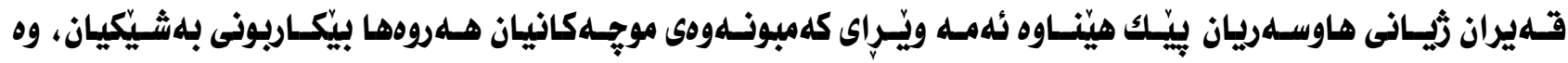

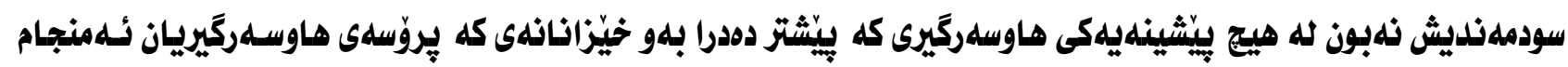

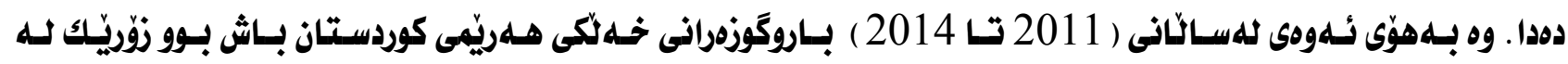

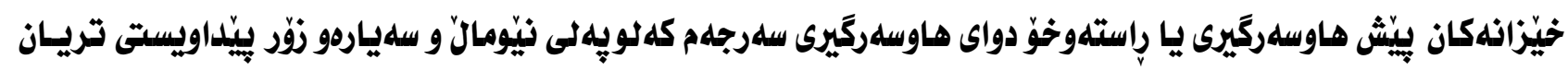

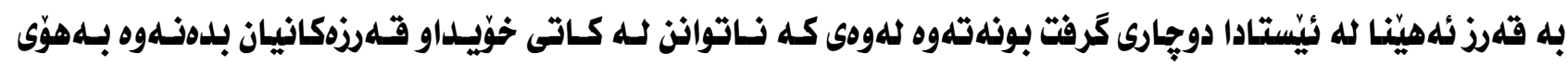

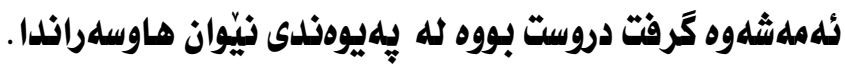

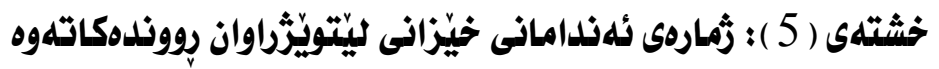

\begin{tabular}{|c|c|c|}
\hline رَّيّزَهى سهدى \% & دوبـارببووهكان & ثمارهى ئلهندامانى خيَّزان \\
\hline$\% 66.66$ & 20 & $3-2$ \\
\hline$\% 33.33$ & 10 & $5-4$ \\
\hline$\%$ & 0 & $7-6$ \\
\hline$\% 99.99$ & 30 & كوّى كَشتى \\
\hline
\end{tabular}

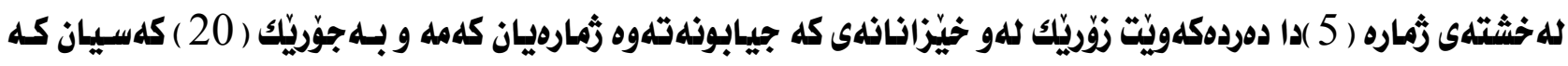

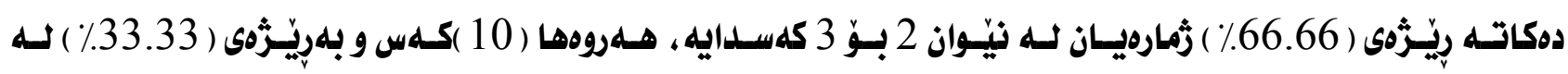

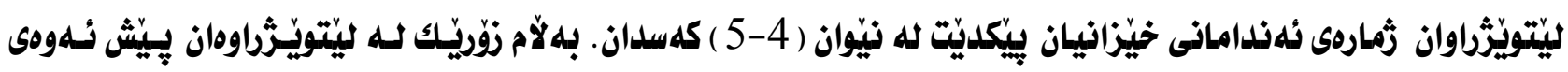

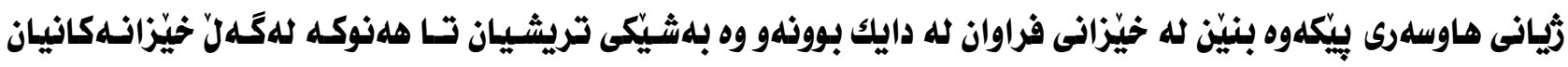




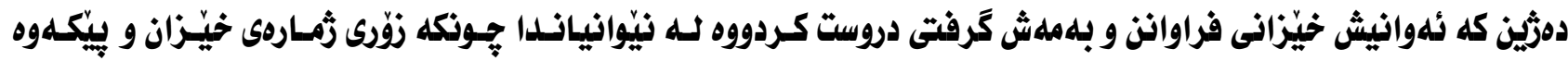

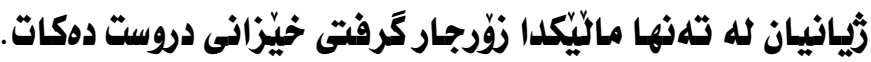

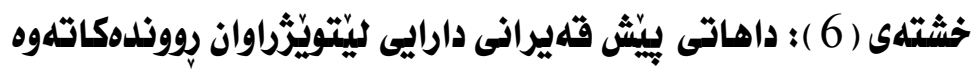

\begin{tabular}{|c|c|c|}
\hline 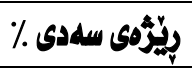 & دووبادربوومكان & دامات \\
\hline$\% 10$ & 3 & زُرباش \\
\hline$\% 66.66$ & 20 & باش \\
\hline$\% 23.33$ & 7 & مام ناوهند \\
\hline$\% 0$ & 0 & خراب \\
\hline \%99.99 & 30 & كوّى كَشتى \\
\hline
\end{tabular}

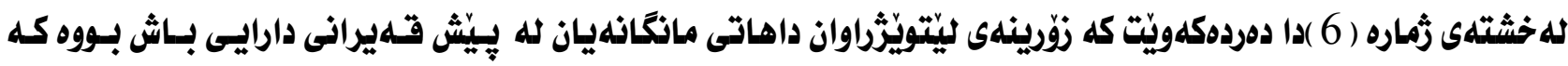

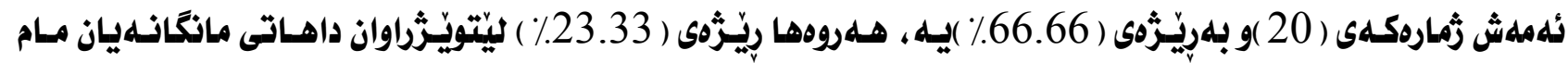

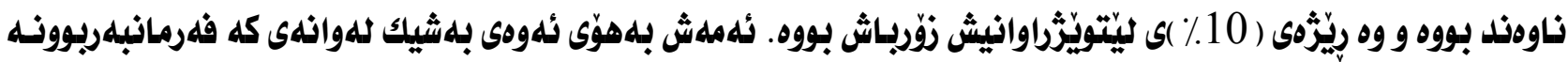

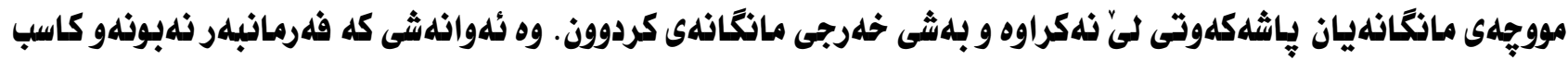

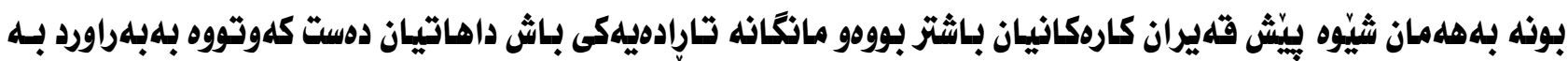
دواى قـيران.

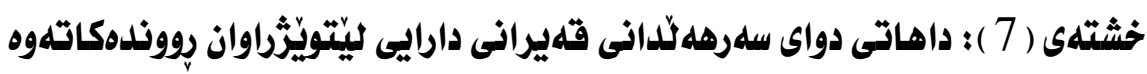

\begin{tabular}{|c|c|c|}
\hline 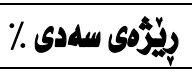 & دوبارهبووهكان & دامات \\
\hline$\% 0$ & 0 & زَرَباش \\
\hline$\% 0$ & 0 & باش \\
\hline$\% 23.33$ & 7 & مام نـاوهند \\
\hline$\% 76.66$ & 23 & خرابٍ \\
\hline$\% 99.99$ & 30 & كوّى كَشتى \\
\hline
\end{tabular}

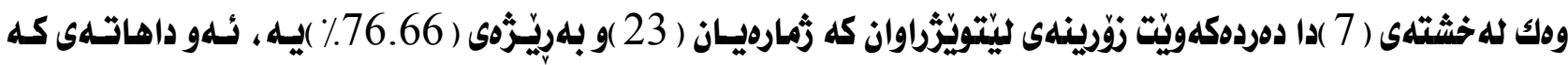

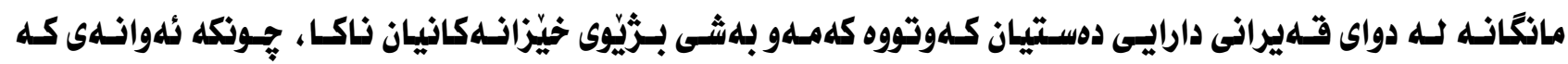

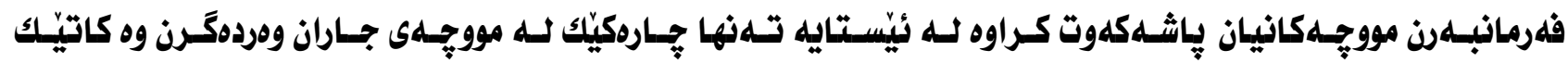

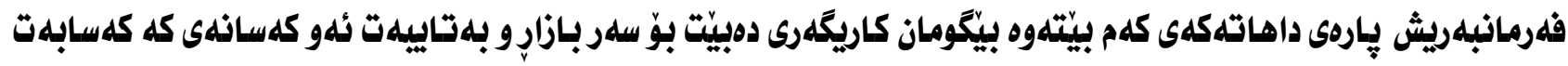

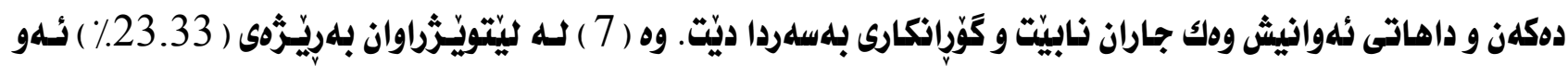

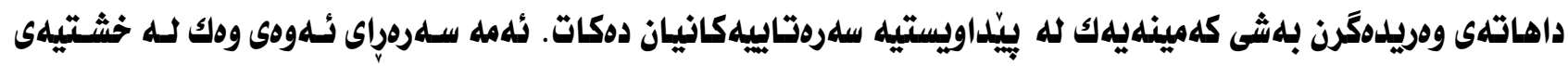

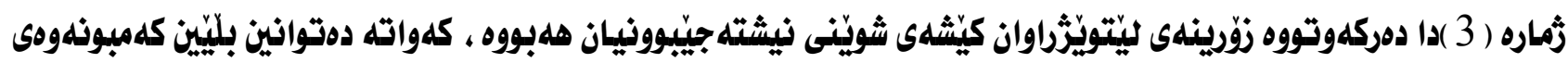

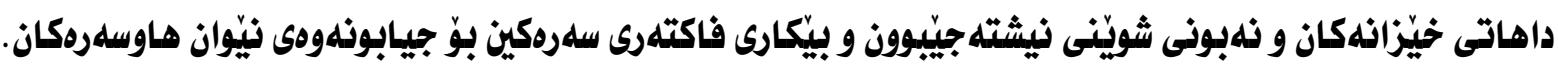


خشتهى ( 8 ) : يِيشهى ليّتِيَّرَاوان رِووندهكاتهوه

\begin{tabular}{|c|c|c|}
\hline 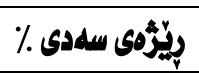 & دوبارهبووهكان & uي \\
\hline$\% 30$ & 9 & كاسب \\
\hline$\% 40$ & 12 & بيكار \\
\hline$\% 30$ & 9 & فهرمانبهر \\
\hline$\% 100$ & 30 & كوّى كَثتى \\
\hline
\end{tabular}

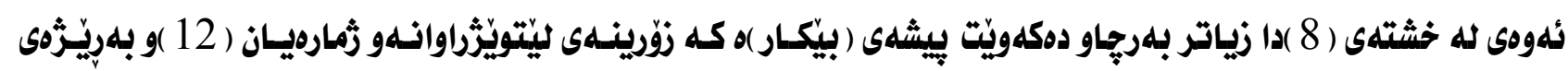

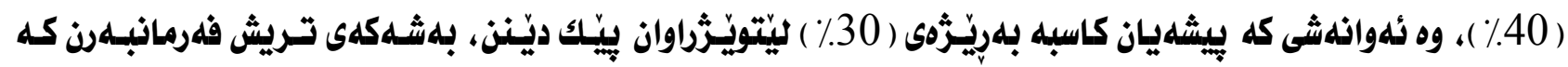

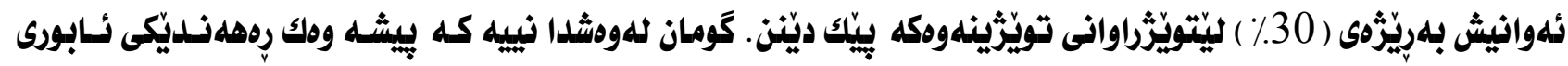

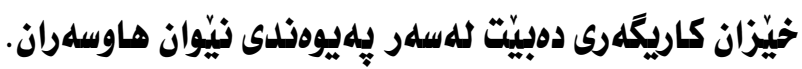

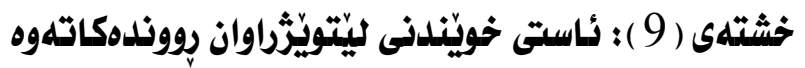

\begin{tabular}{|c|c|c|}
\hline رِيَّرَى سهدى \% & دوبـارهبووهكان & ناستى خوينّلدن \\
\hline$\% 10$ & 3 & نه خويّندهوار \\
\hline$\% 30$ & 9 & سلهرهتايى \\
\hline$\% 10$ & 3 & ناوهندى \\
\hline$\% 10$ & 3 & ئامادهيى \\
\hline$\% 10$ & 3 & زانكوّ" \\
\hline$\% 30$ & 9 & يه يمانكا \\
\hline$\% 100$ & 30 & كوّى كَثتى \\
\hline
\end{tabular}

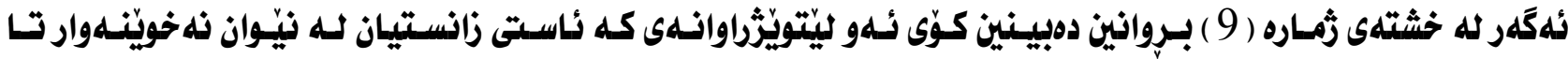

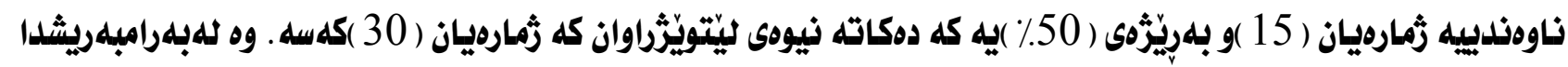

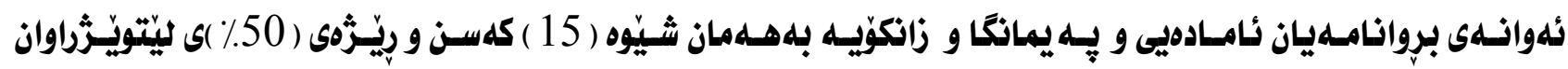

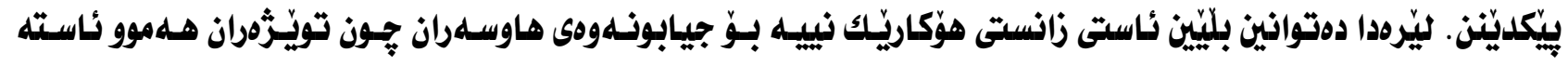
زانستيلكانيان وهركرتووه، له دهره نجاميشدا دهركهوتووه كه جيابونهوه له نيّوان هلموو نئاستهكان هلهيه و تاييهت نييه بله ئاستئكى دياريكراو.

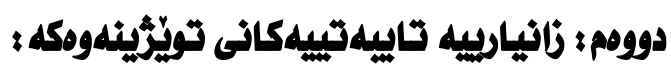

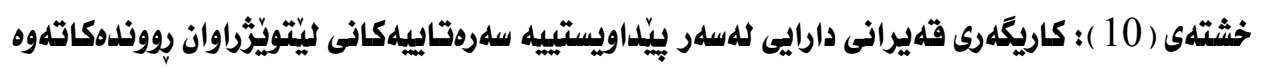

\begin{tabular}{|c|c|c|}
\hline ريّرَّهى سهدى \% & دوبارهبووهكان & 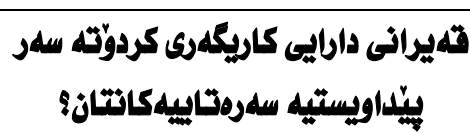 \\
\hline$\% 60$ & 18 & بلهلى" \\
\hline$\% 40$ & 12 & نهخيّر \\
\hline$\% 100$ & 30 & كوّى كَثتى \\
\hline
\end{tabular}




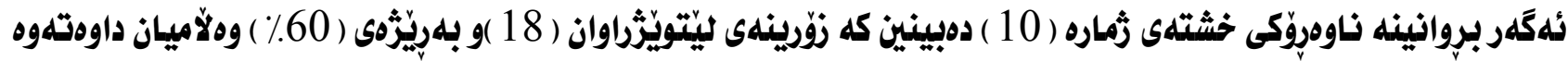

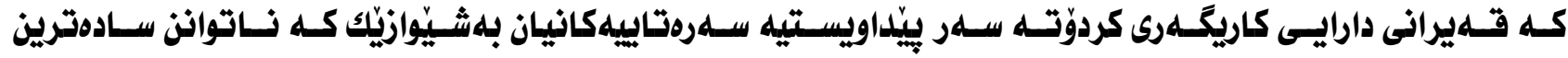

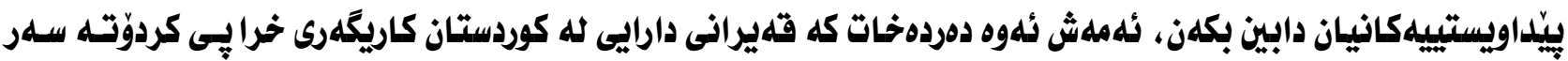

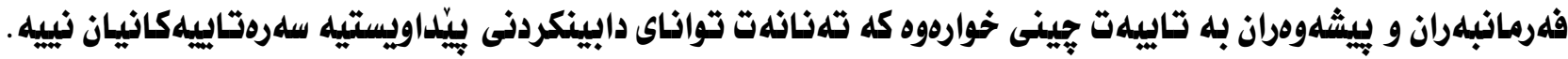

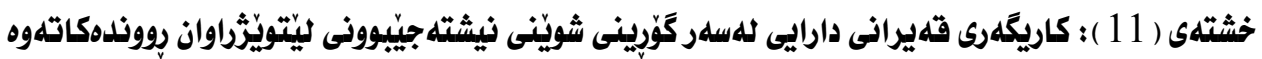

\begin{tabular}{|c|c|c|}
\hline 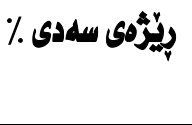 & دوبارهبووهكان & 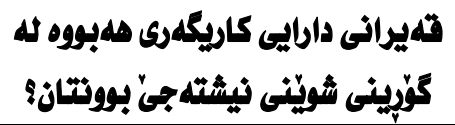 \\
\hline$\% 60$ & 18 & بلهلى \\
\hline$\% 40$ & 12 & نه خيّر \\
\hline$\% 100$ & 30 & كوّى كَثتى \\
\hline
\end{tabular}

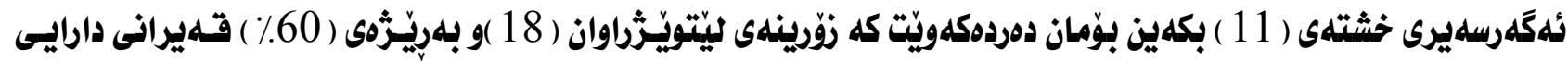

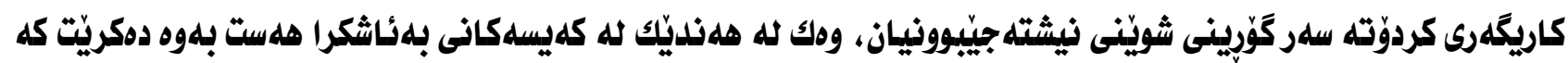

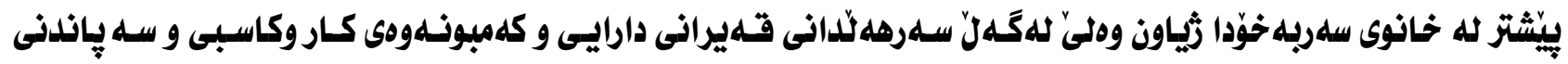

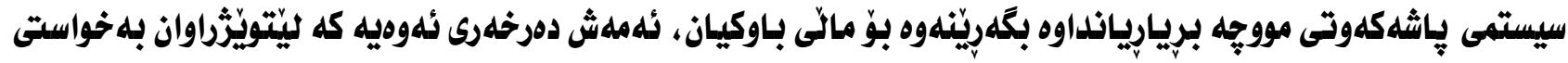

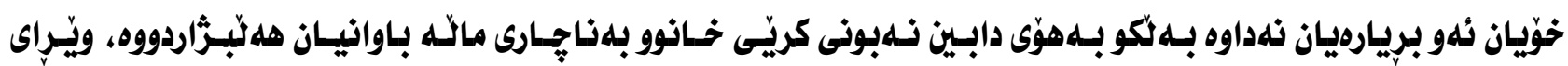

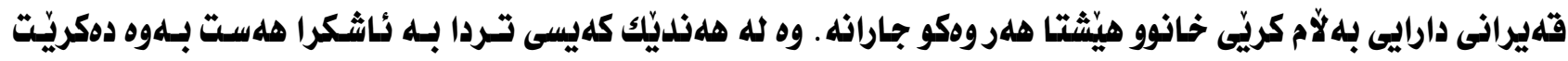

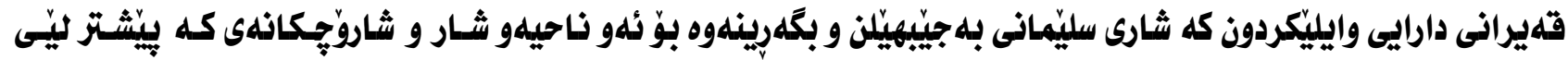

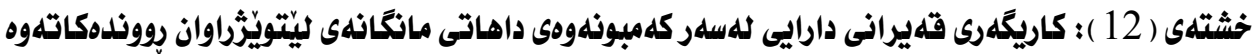

\begin{tabular}{|c|c|c|}
\hline ريّزئمى سهدى \% & دوبارهبووهكان & 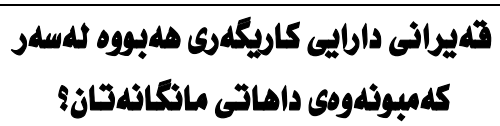 \\
\hline$\% 90$ & 27 & بلهلى" \\
\hline$\% 10$ & 3 & نه خيّر \\
\hline$\% 100$ & 30 & كؤى كَثتى \\
\hline
\end{tabular}

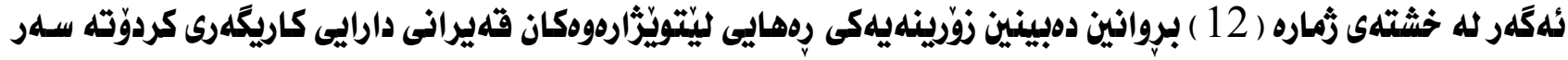

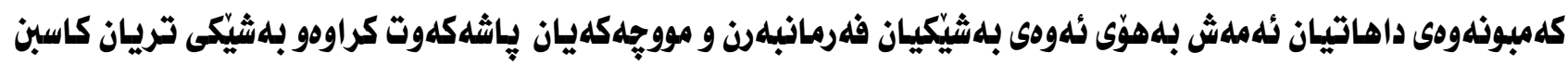

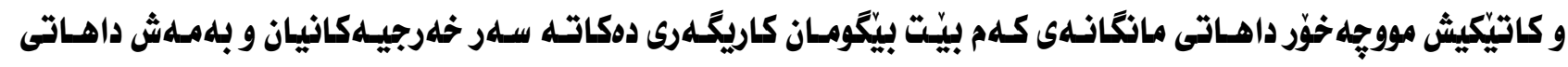

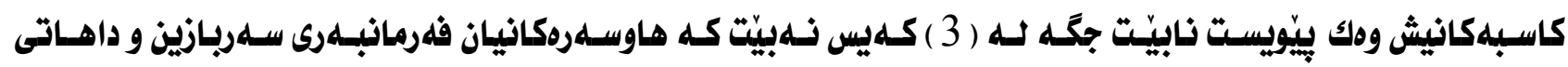

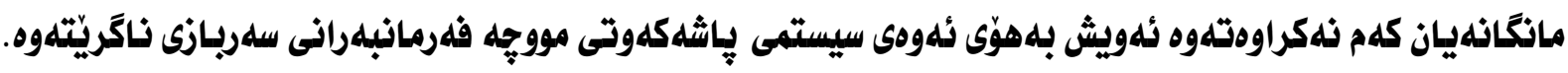


خثتهى ( 13 ) : كاريكَرى قهيرانى دارايى للهسهر قهرزاربونى ليّتويُّراوان رِووندهكاتهوه

\begin{tabular}{|c|c|c|}
\hline 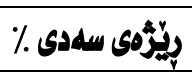 & دوبارببووهكان & تهيرانى دارايق بوّته هوّى لَهزاربونتان? \\
\hline$\% 50$ & 15 & بلهلّي \\
\hline$\% 50$ & 15 & نهخيُر \\
\hline$\% 100$ & 30 & كوّى كَشتتى \\
\hline
\end{tabular}

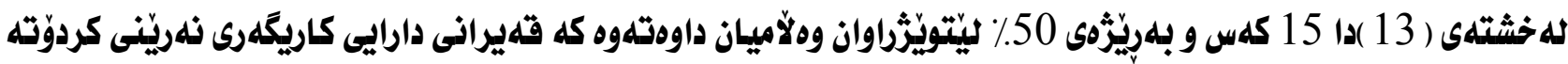

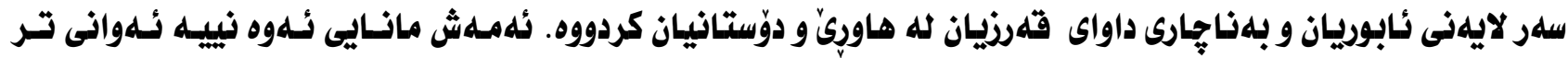

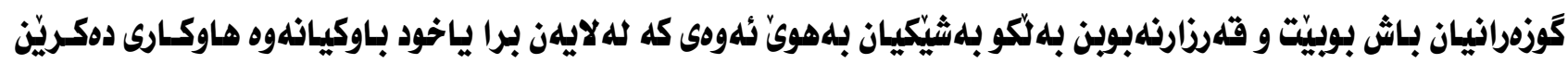

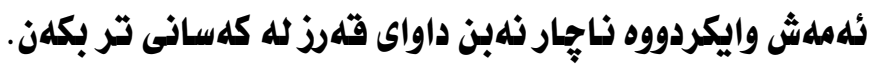
خشتهى ( 14 ) : كاريكهرى قهيرانى دارايى للهسر بيّكارى ليّتويّرَراوان رووندوكاتهوه

\begin{tabular}{|c|c|c|}
\hline 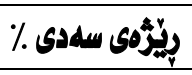 & دوبارهبووهكاز & قديرانى دارايى بوّته هوى" بيكاربونتُ \\
\hline$\% 40$ & 12 & بلهلى" \\
\hline$\% 60$ & 18 & نه خيّر \\
\hline$\% 100$ & 30 & كوّى كَشتى \\
\hline
\end{tabular}

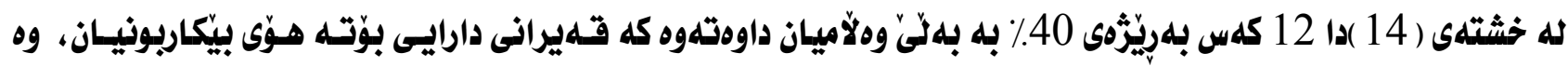

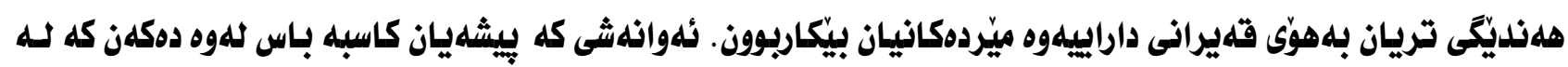

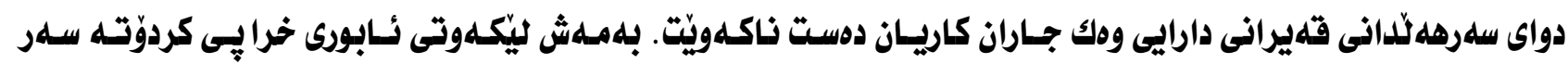

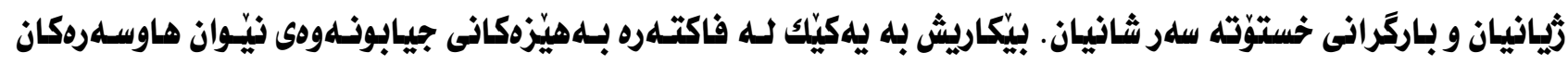

دادهذريّت.

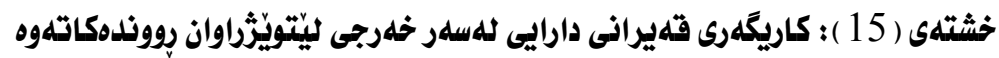

\begin{tabular}{|c|c|c|}
\hline 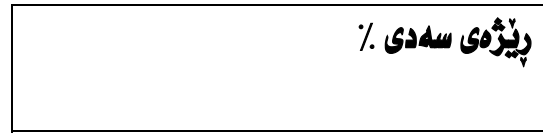 & دوبارهبووهكان & 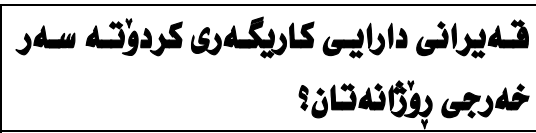 \\
\hline$\% 100$ & 30 & بلهلى" \\
\hline$\% 0$ & 0 & نه خيّر \\
\hline$\% 100$ & 30 & كوّى كَثتى \\
\hline
\end{tabular}

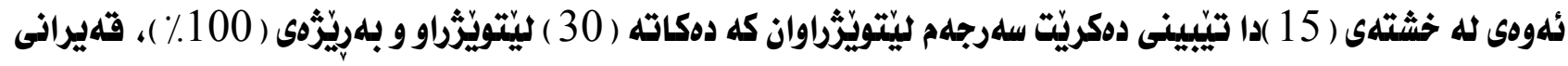

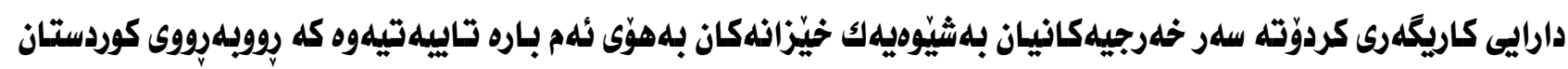

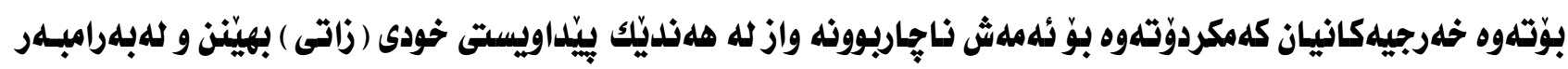
دابينكردذى خهرجى مندالهكانيانلا. 


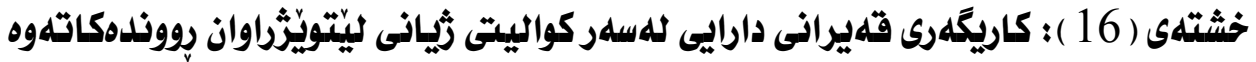

\begin{tabular}{|c|c|c|}
\hline ريّرَهى سهدى \% & دووبارهبووهكان & قديرانى دارايى كاريكهرى هلبووه للهسلهر كواليتى \\
\hline$\% 100$ & 30 & بلكلى \\
\hline$\% 0$ & 0 & نهخيُر \\
\hline$\% 100$ & 30 & كوّى كَثتى \\
\hline
\end{tabular}

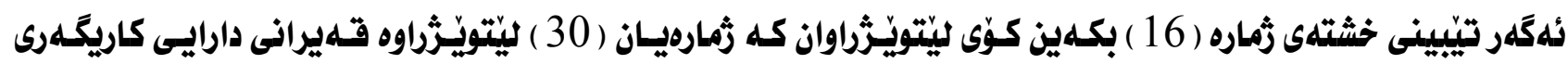

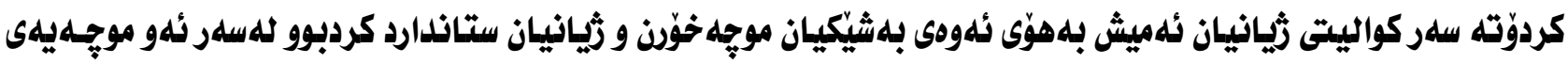

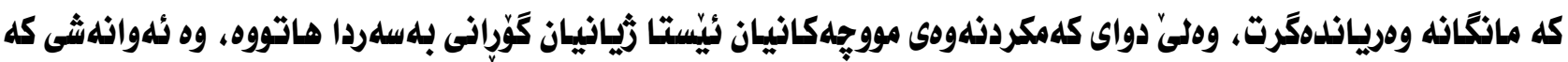

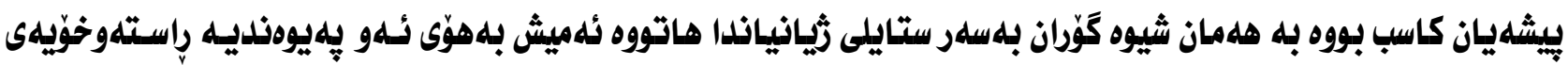
كه للهنيوان مووجه و دهستى كارو بيشهدا هلهيه.

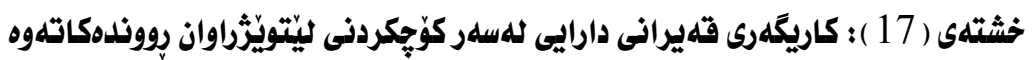

\begin{tabular}{|c|c|c|}
\hline رِيّرَمى سلددى & دوبارهبووهكان & دوايى سلهرهدلادانى خهيرانى دارايى بيرت \\
\hline$\% 76.66$ & 23 & بلهلّ \\
\hline$\% 23.33$ & 7 & نهخيُر \\
\hline$\% 99.99$ & 30 & كوّى گَثَتى \\
\hline
\end{tabular}

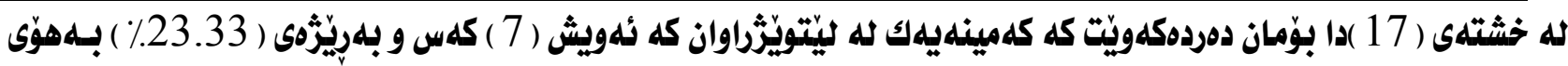

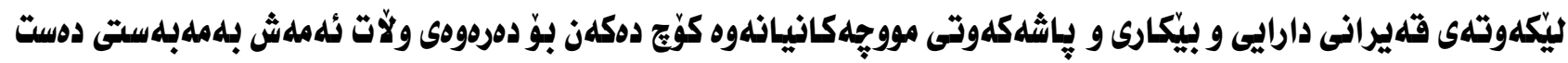

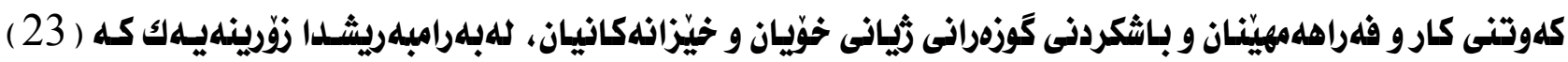

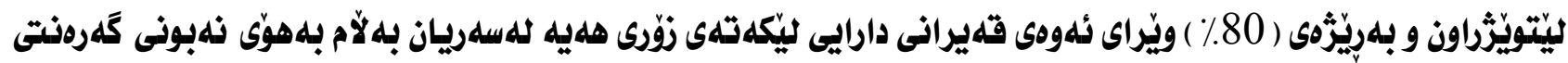

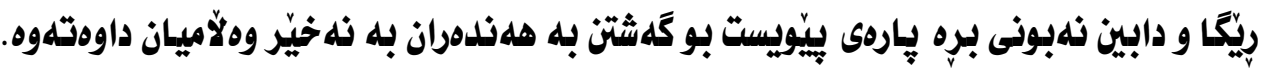

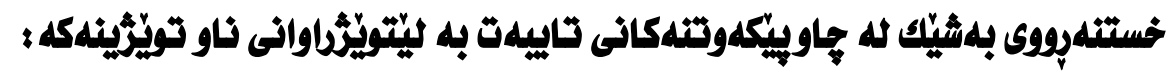

Case study (1)

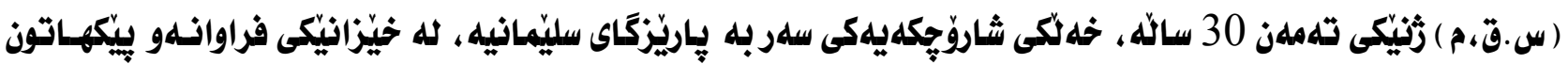

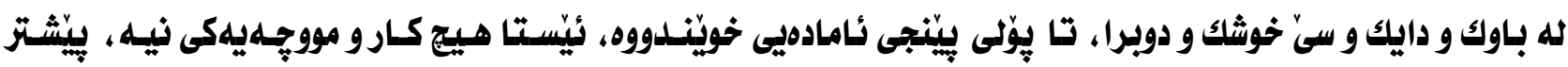

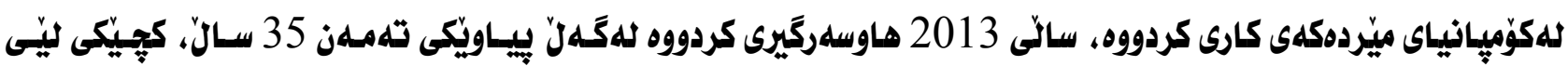

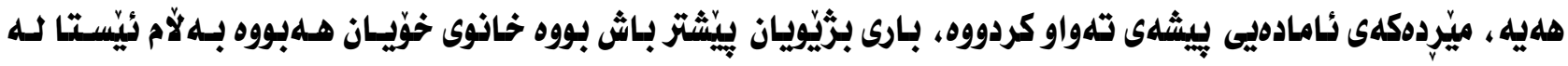

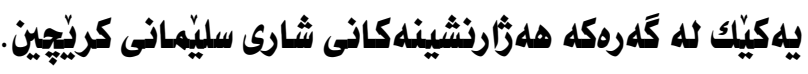

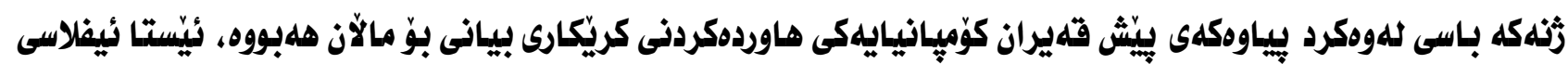

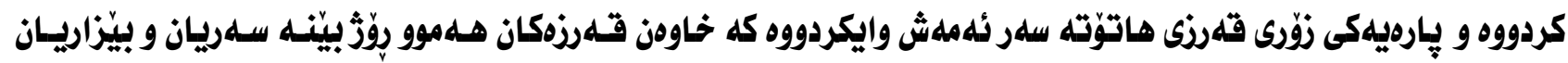

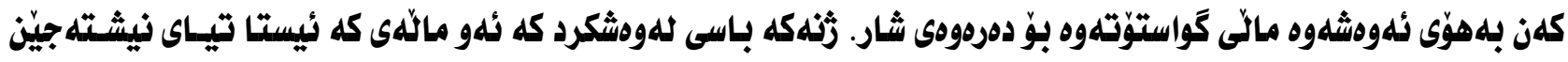




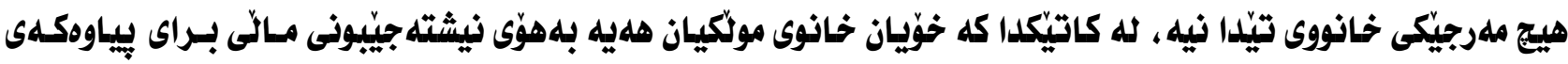

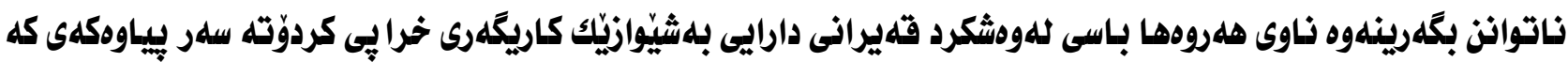
ناتوانى يِيّداويستيه سلهروتاييهكانى مالّهوه دابين بكات.

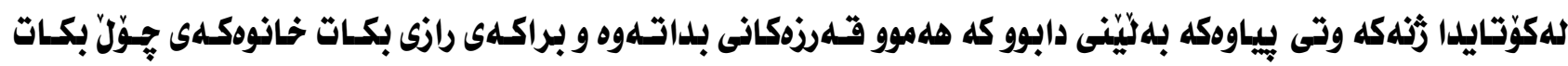

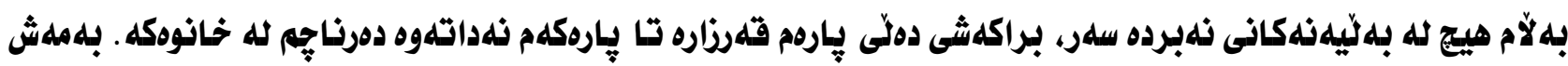

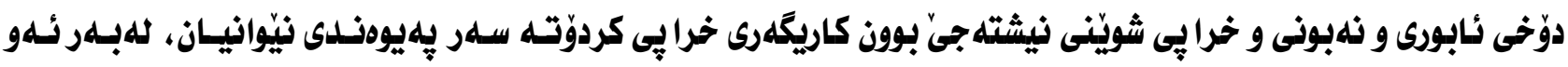

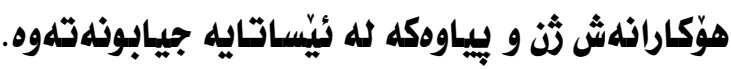

Case study (2)

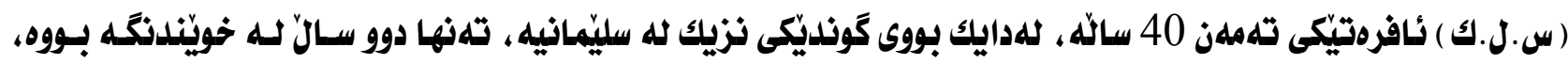

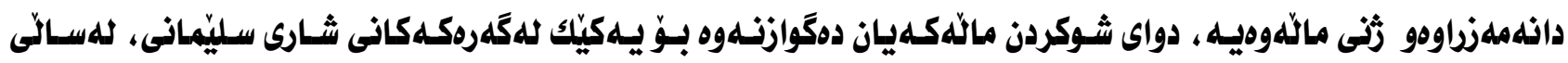

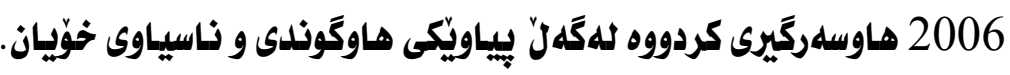

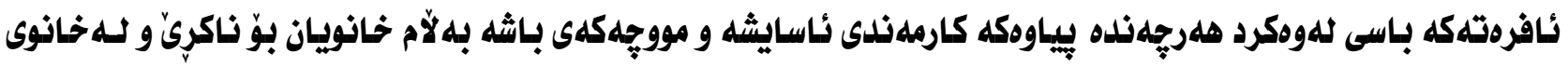
كريّلا نيشته جيّى كردوون و ماوهيهكيشه كريّى خانوهكهيان نادات، بـاسى لهوهشكرد بيياوهكهى هيج هاوكاريـان ناكـات و بـوّ

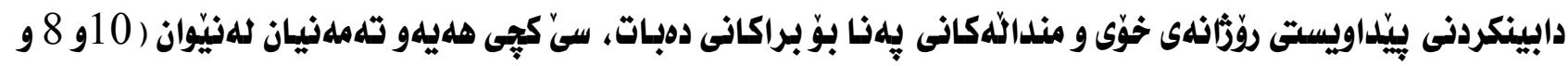

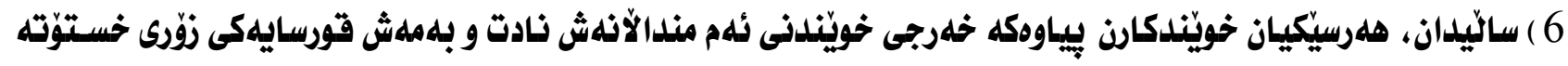

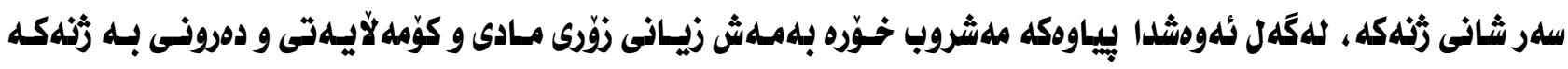

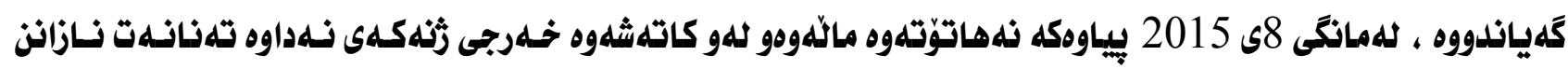
لهوكيّشه.

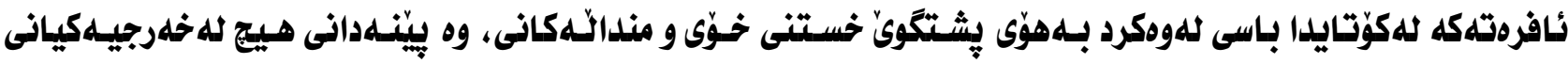

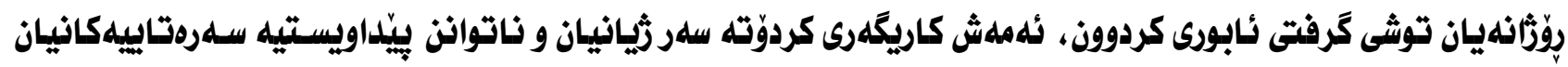

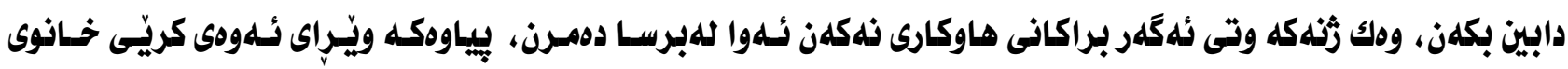

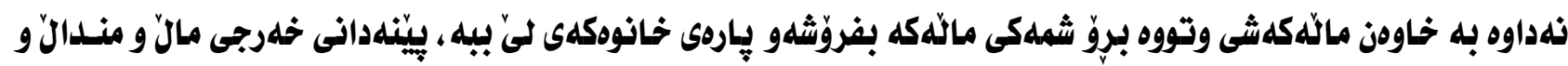

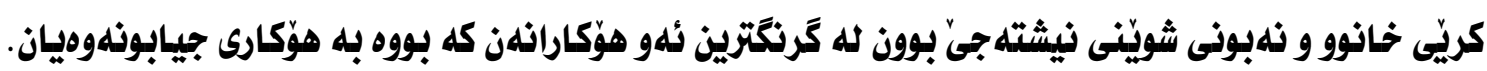

Case study (3)

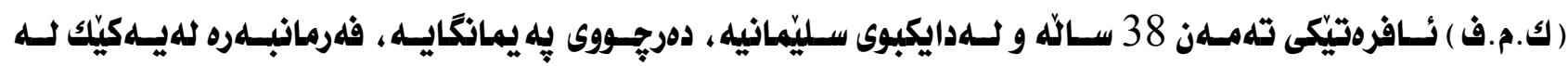

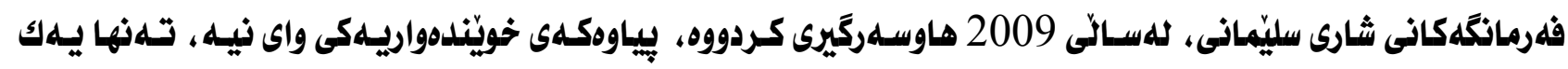

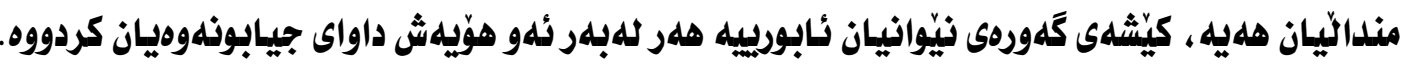

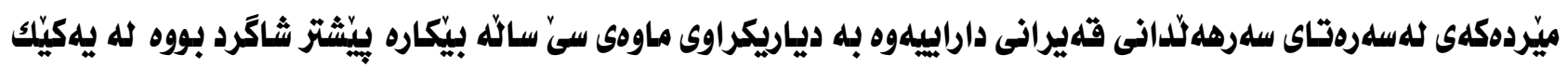

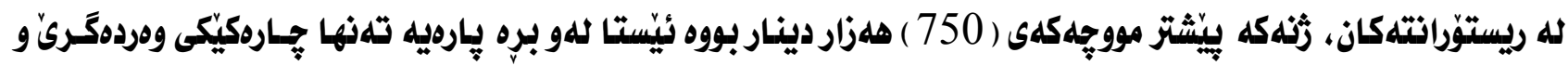




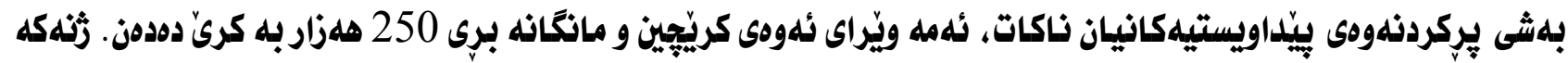

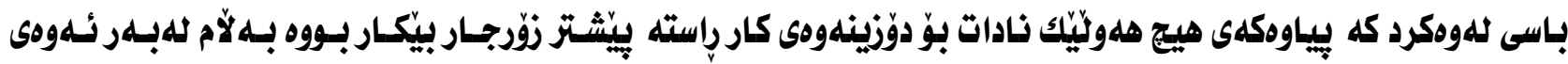

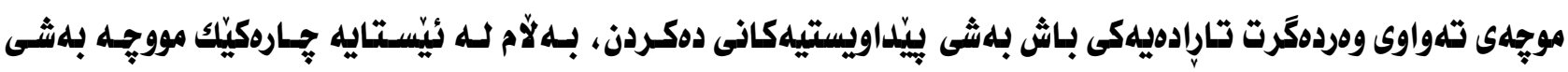

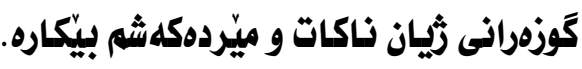

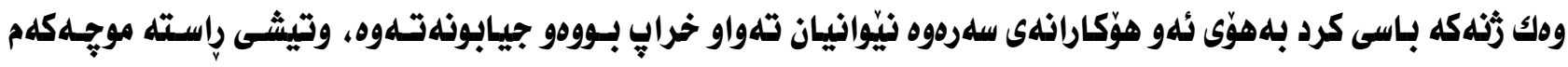

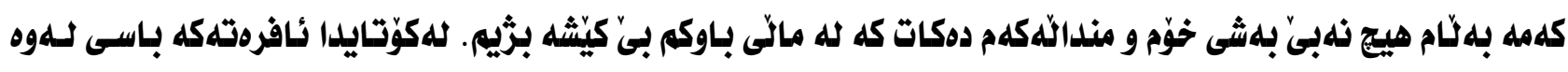

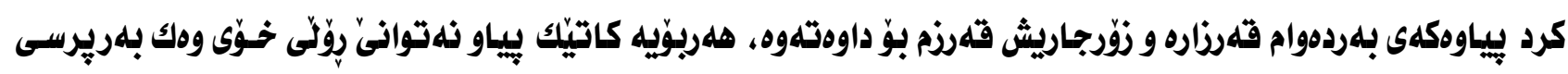

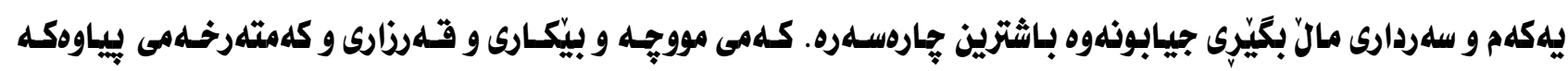

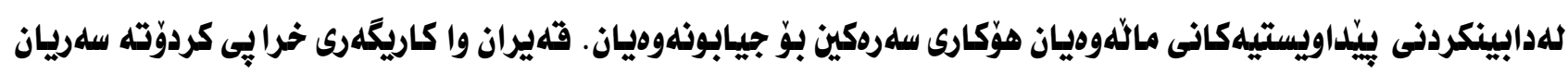

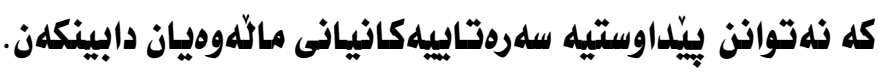

Case Study (4)

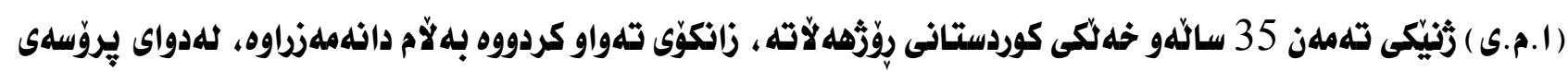

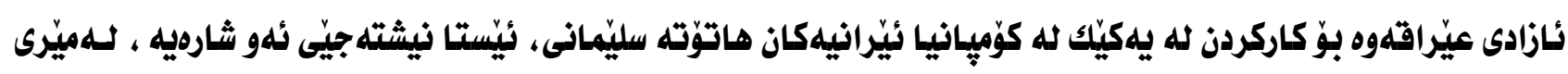

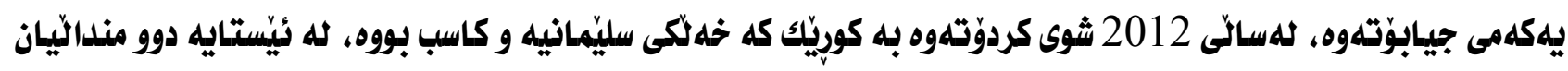

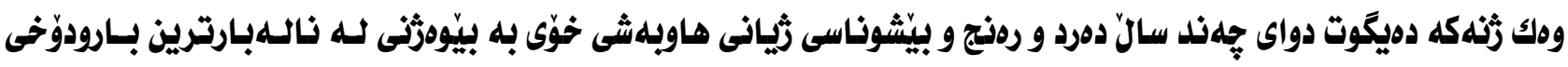

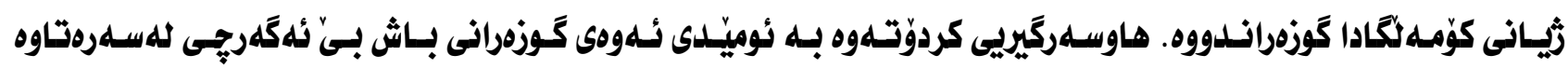

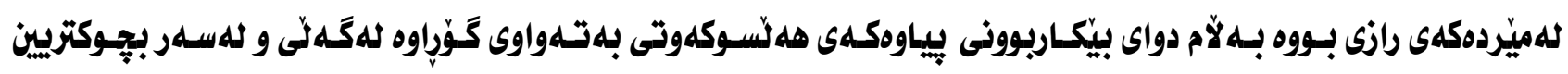

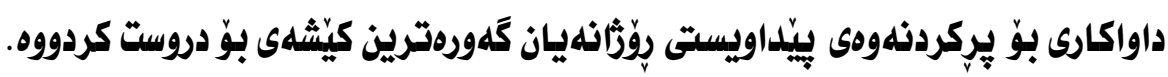

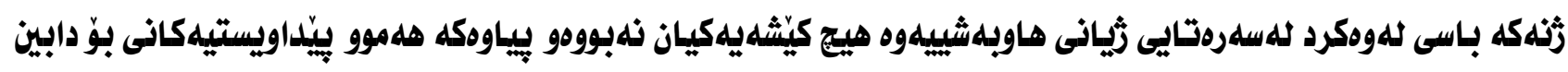

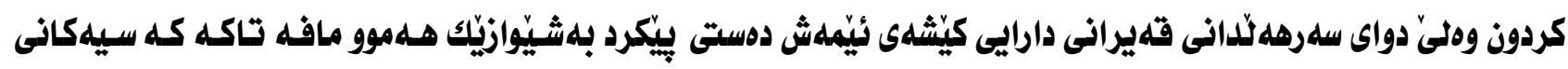

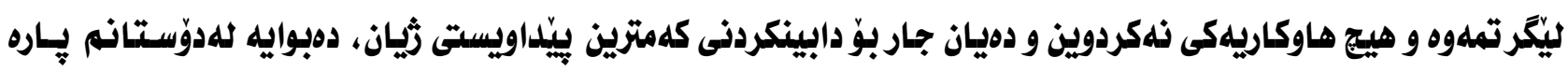
قهرزبكهم.

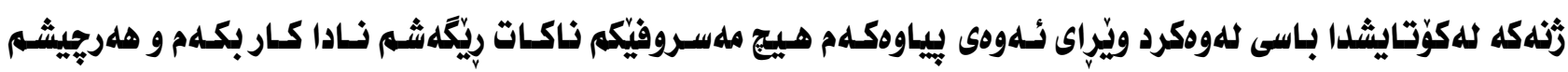

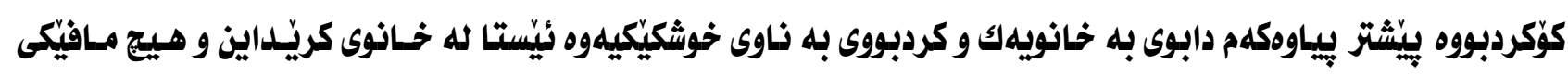

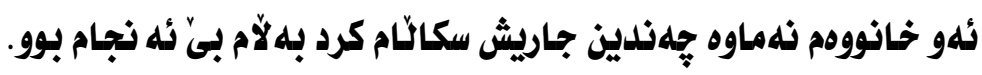

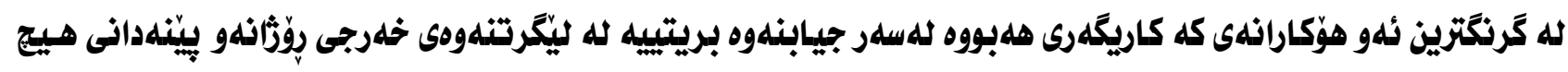

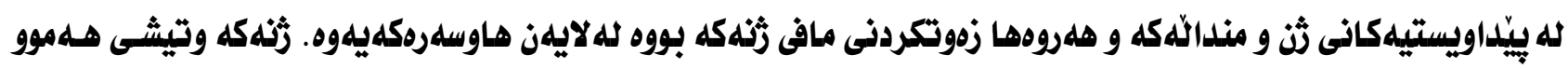




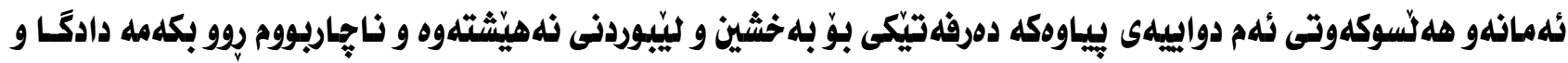
جيابينهوه.

Case study (5)

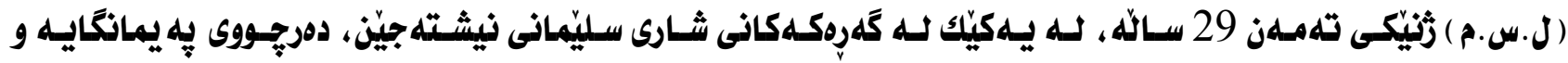

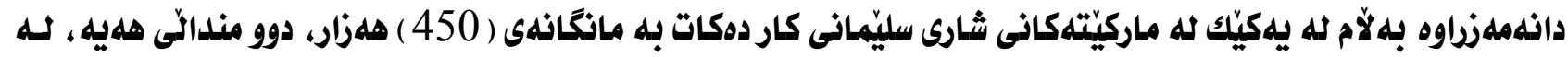

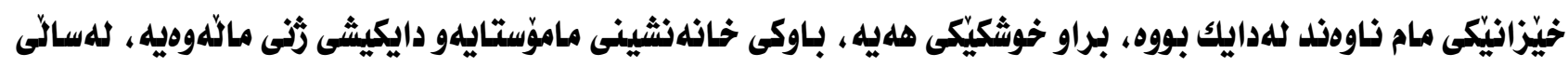

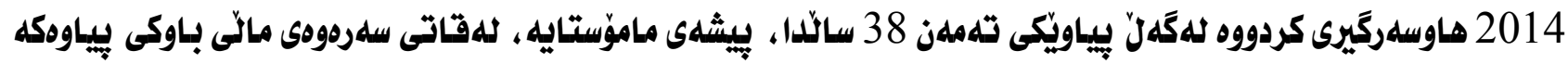

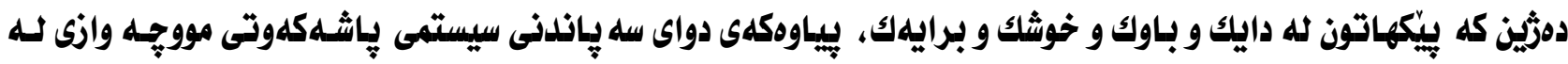

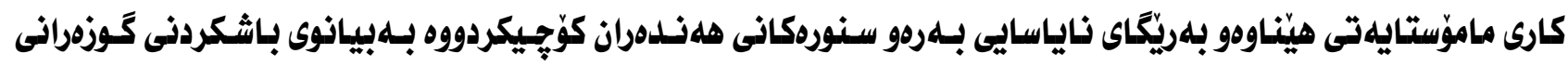

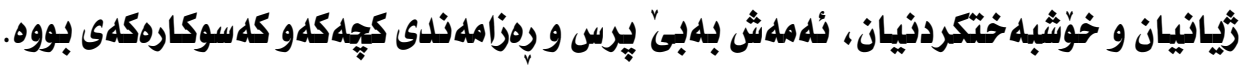

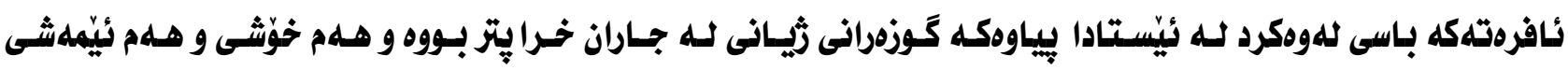

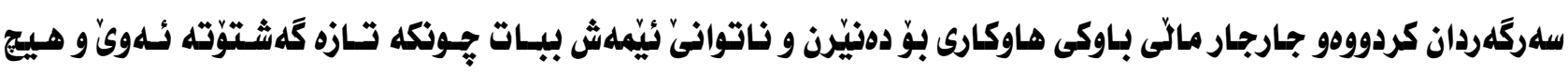

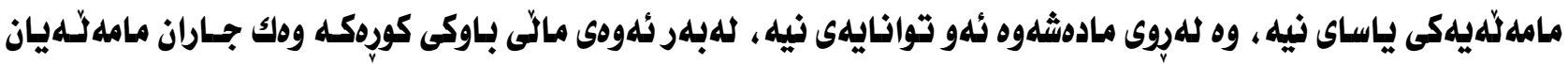

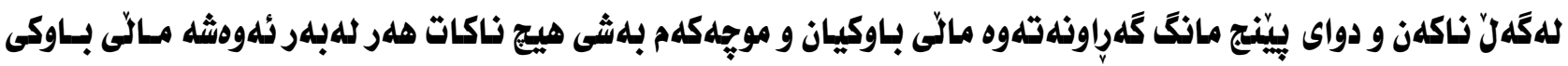
خهرجى و يبيداويستيهكانيان دابين دهكلن.

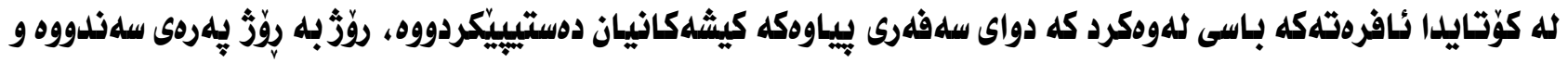

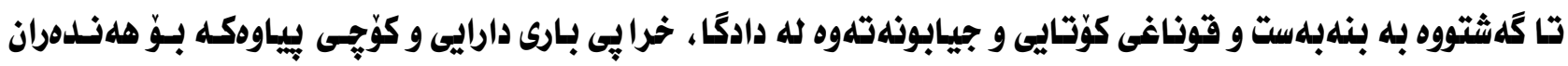

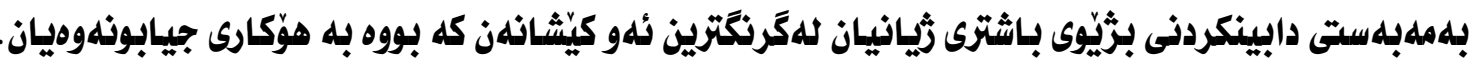

Case study (6)

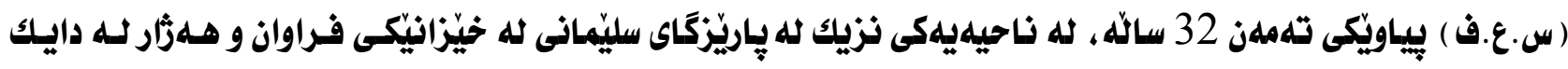

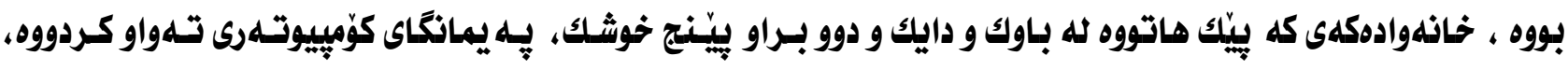

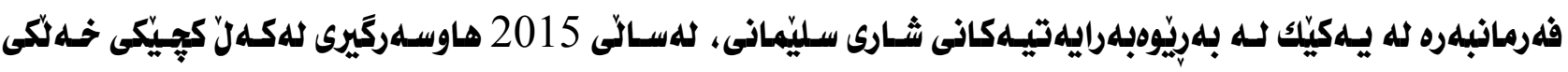

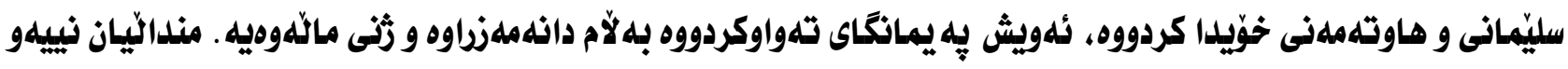

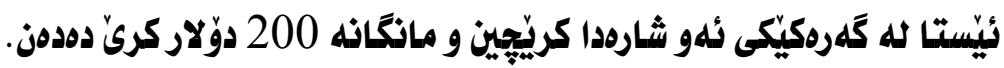

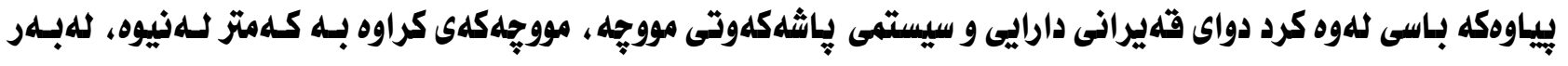

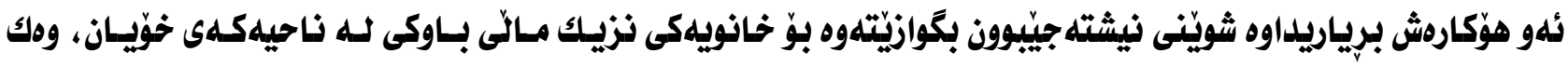

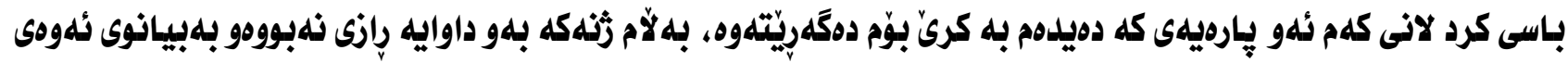

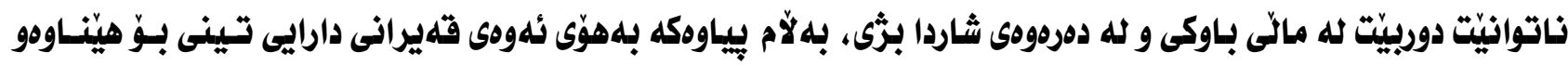

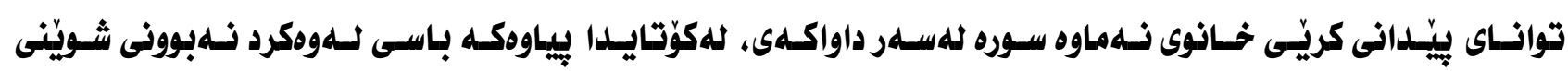




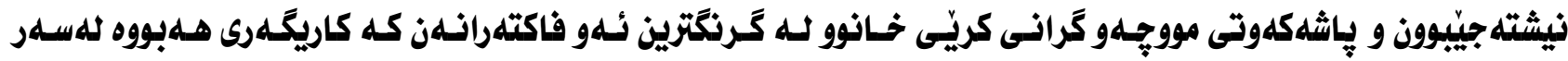

جيابونلهوهى نيّوانيان.

Case study (7)

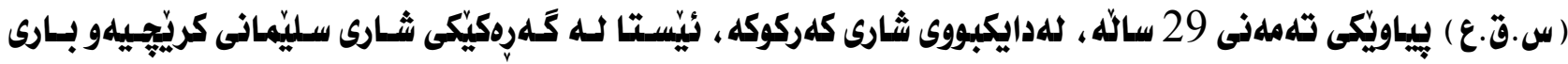

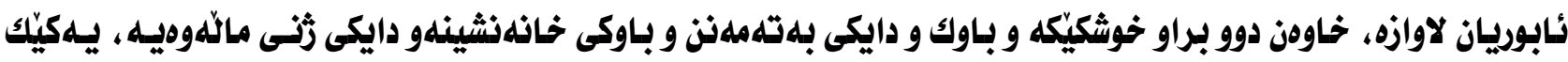

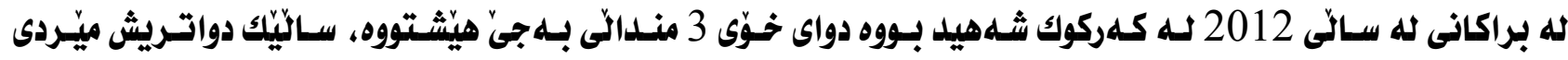

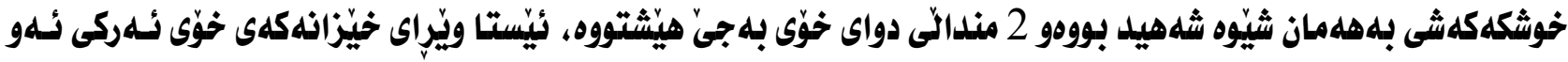

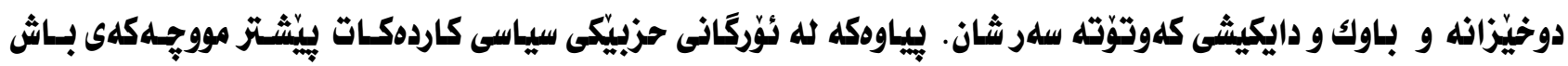

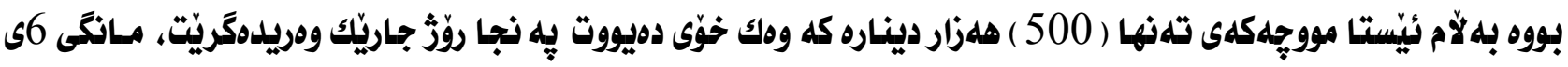

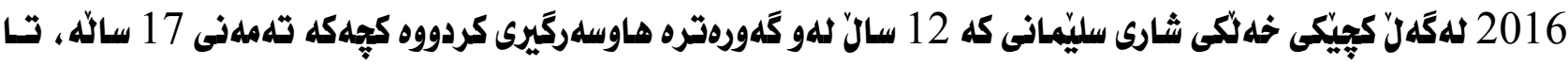

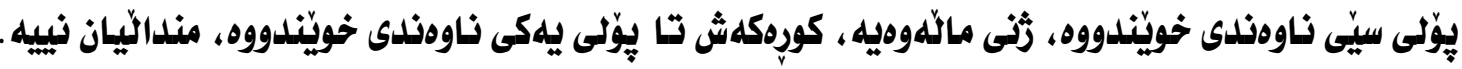

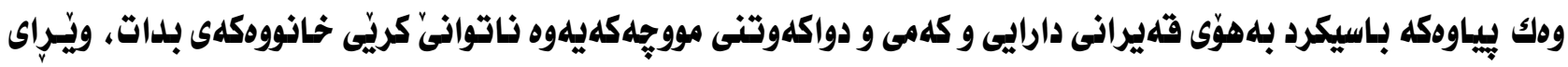

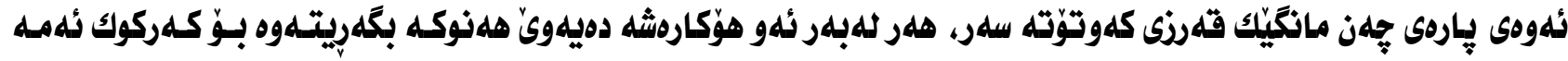

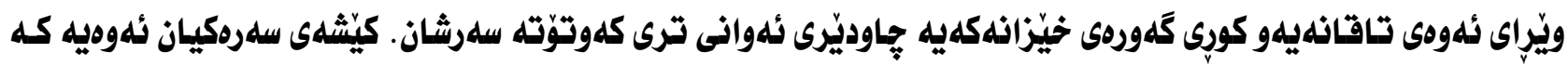

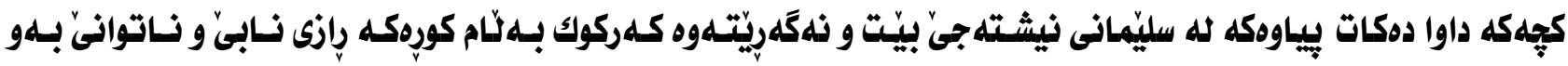

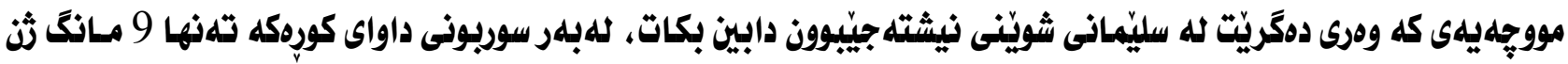
و ميّرد بونهو لله مانكى نُازارى 2017 جيابونهوورتهوهـ.

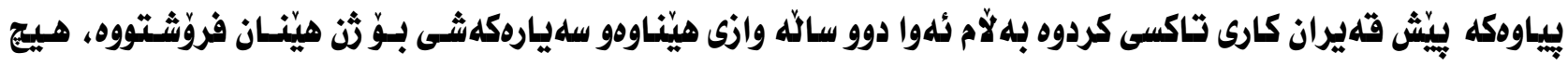

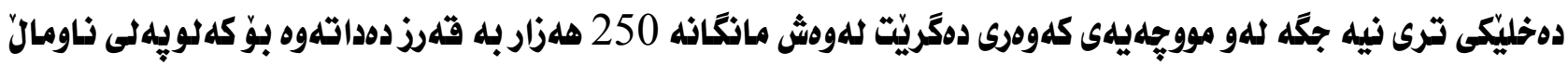

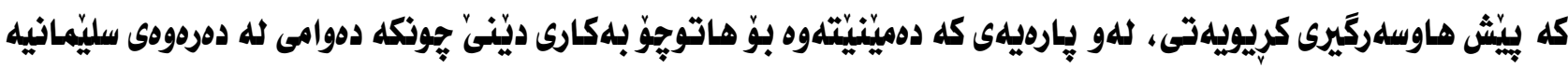

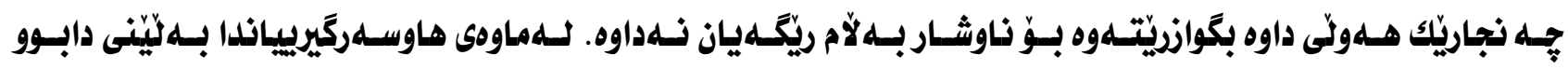

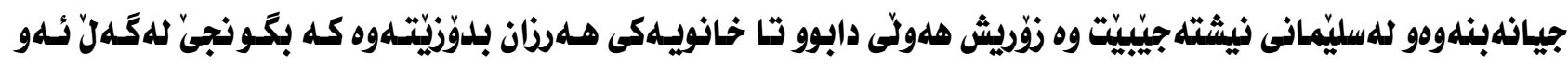

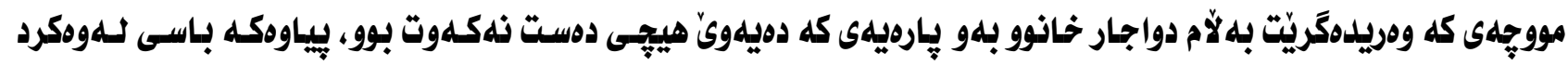

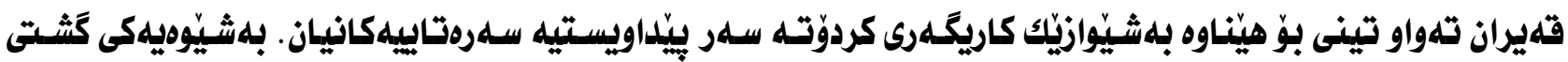

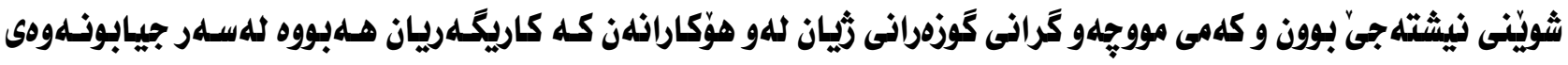

نيّوانيان.

Case study (8)

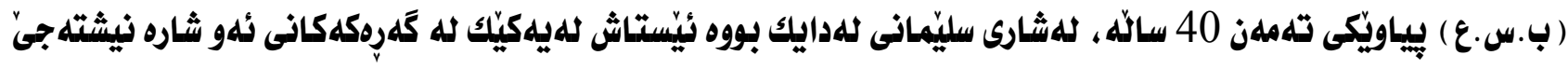

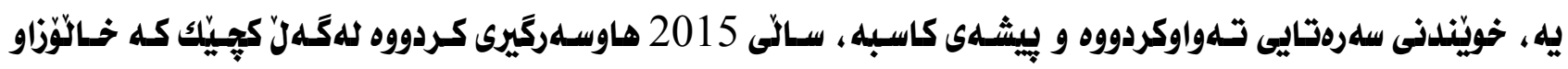




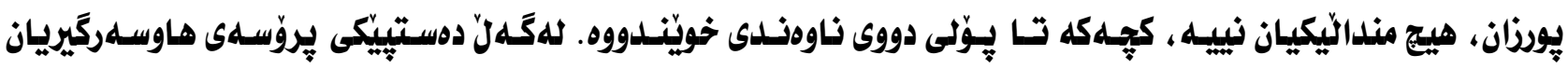

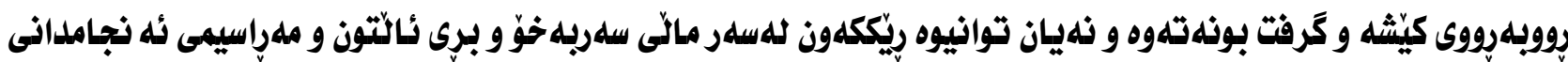
تُاهلنظى هاوسهركَيريان.

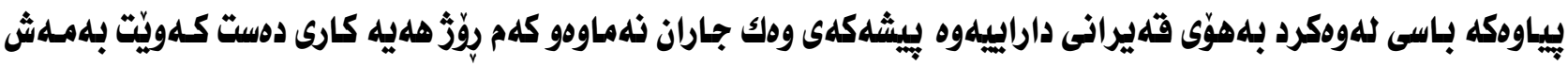

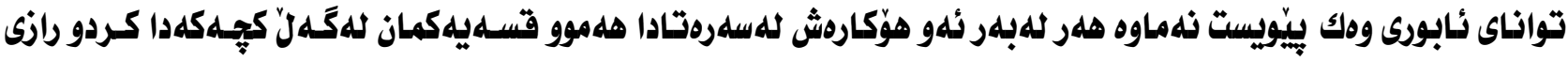

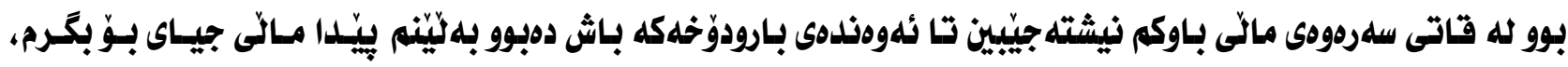

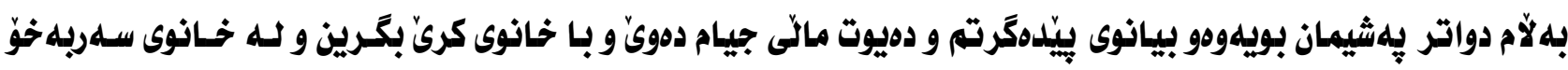
ذلهبى ناتوانم بمينّمهوه لهَّلَّ.

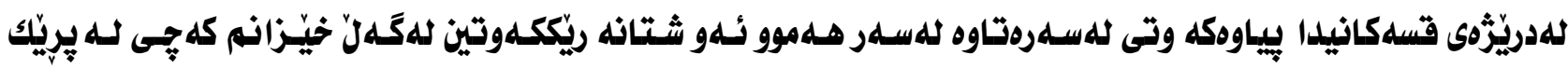

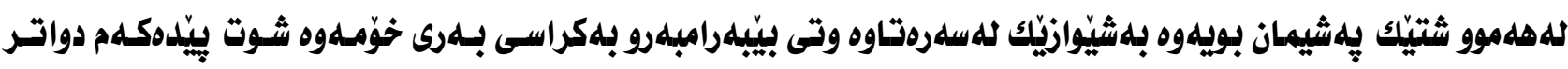

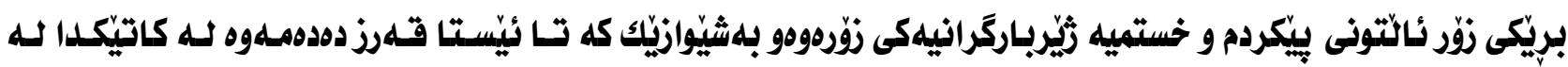

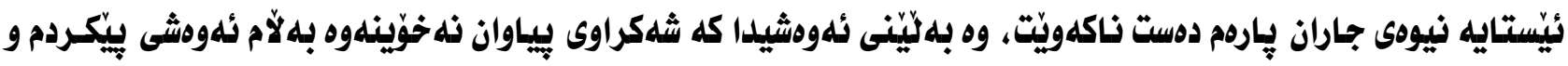

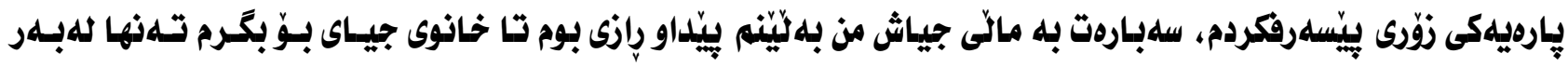

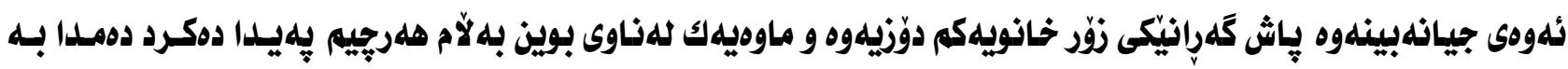

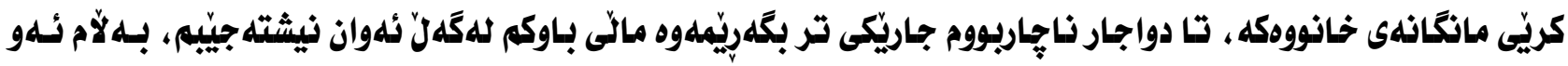

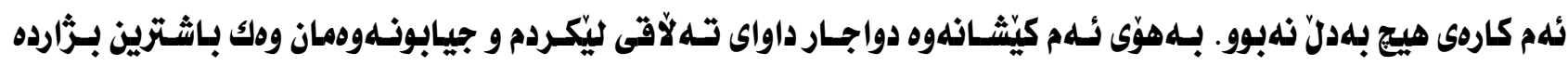

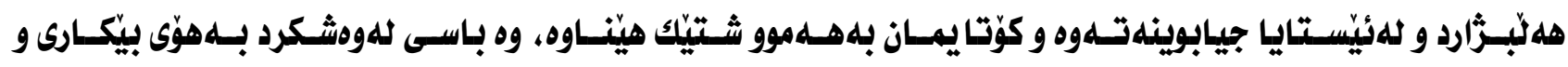

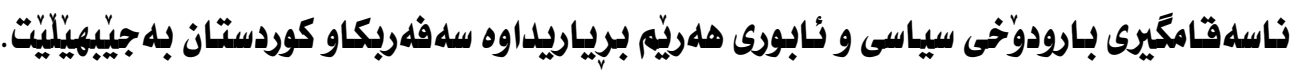

Case study (9)

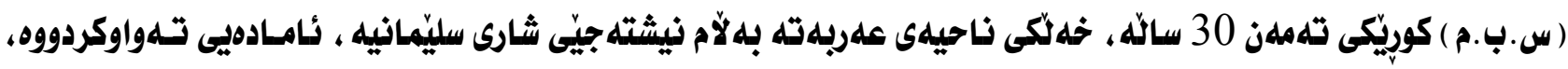

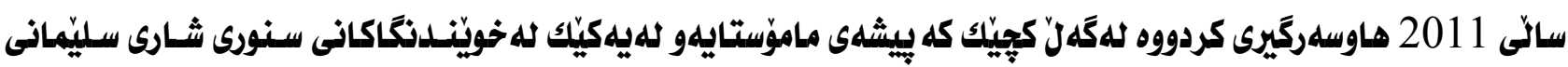

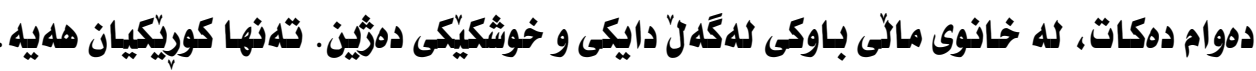

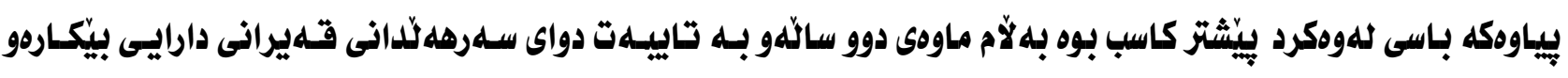

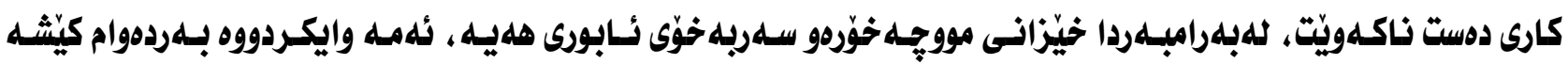

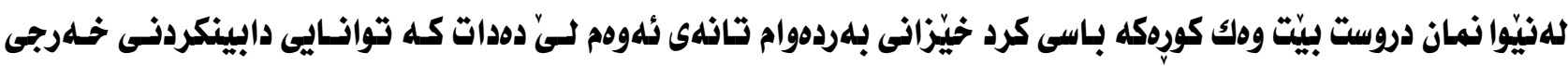

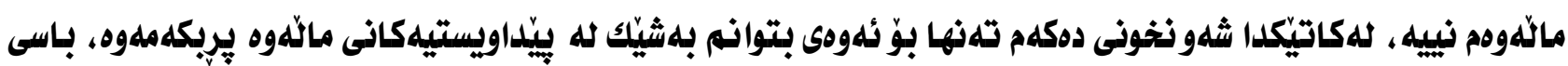

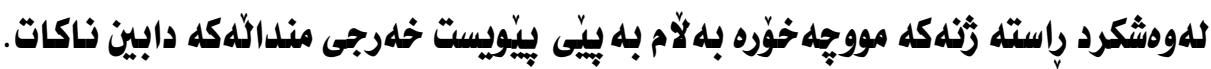

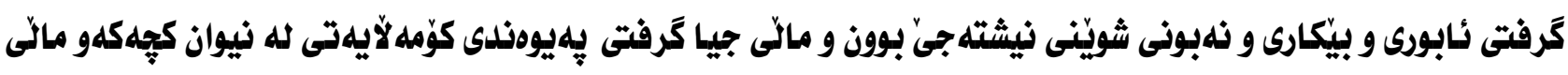

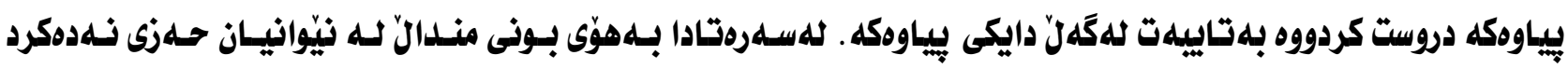

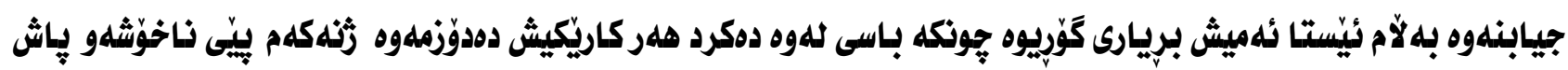
80 | acadj@garmian.edu.krd Vol.5, No.1 (May, 2018) 


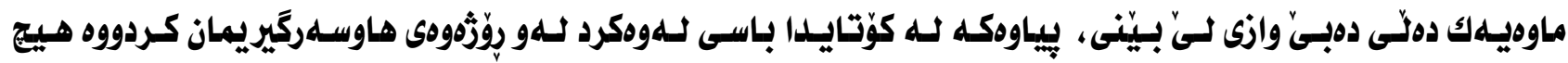

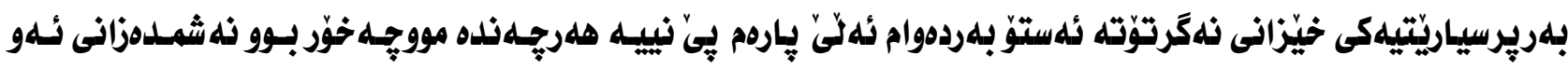

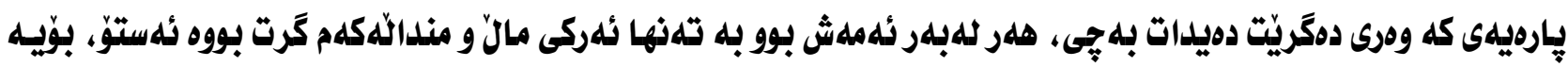
للهبلهر ئلهو هؤكاراذهى سلهرهوه ئيستايدا جيابوينهتموه.

Case study (10)

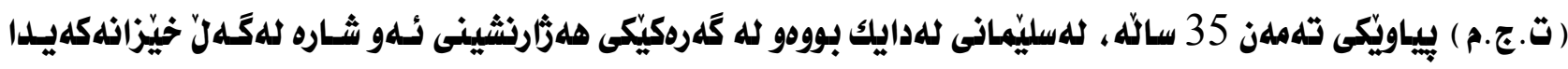

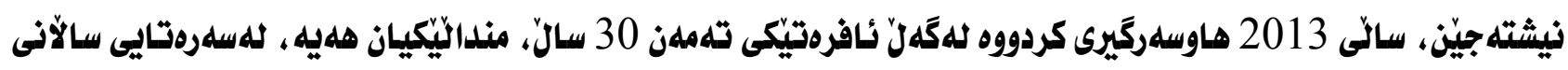

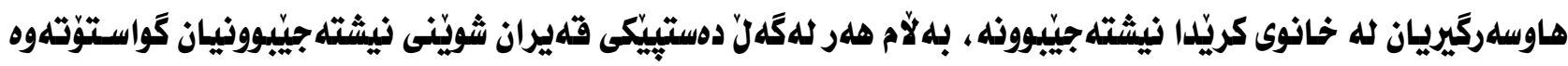

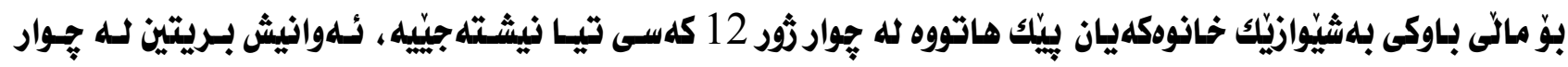

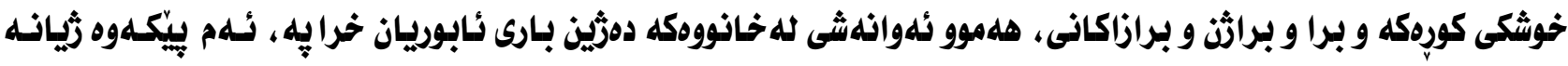
كَرفتى گَلهورهى دروست كردووه له نيّوانيان، بيباوهكه تا يوّلى دووى ناوهندى خويّندووه و دانهملزراوه و كـارى تاكسى دهكـا

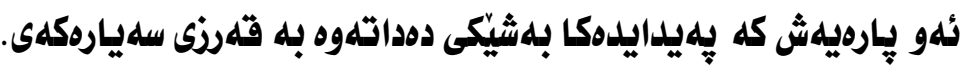

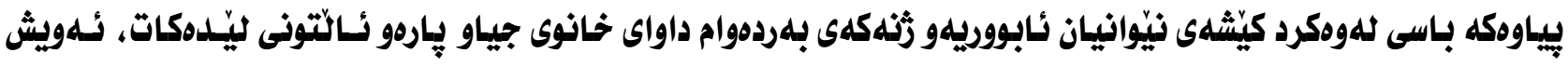

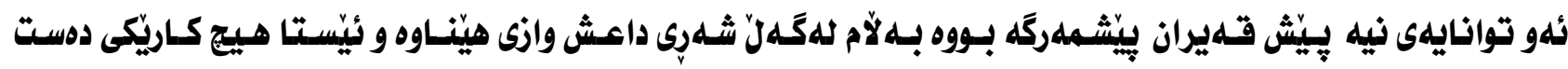

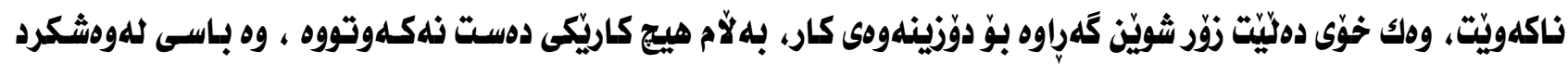

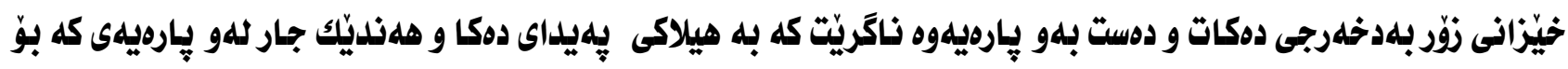

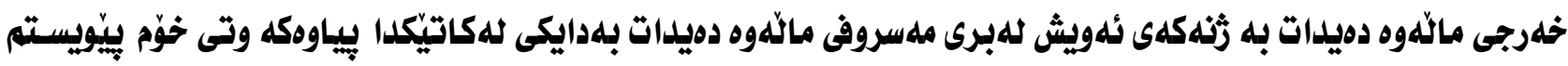

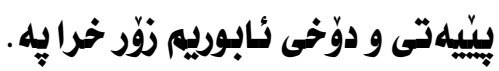

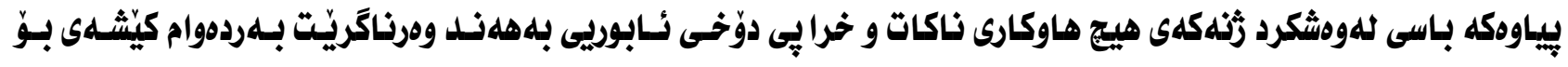

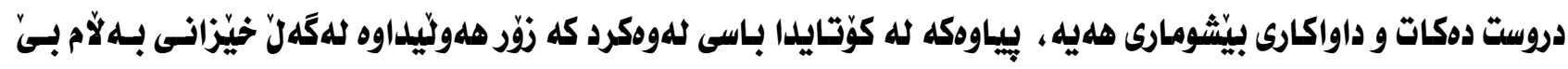

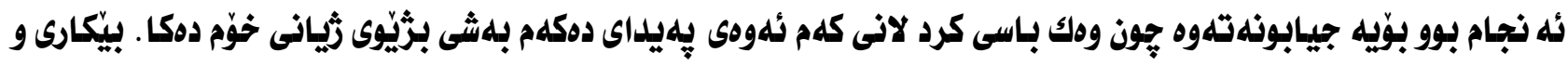

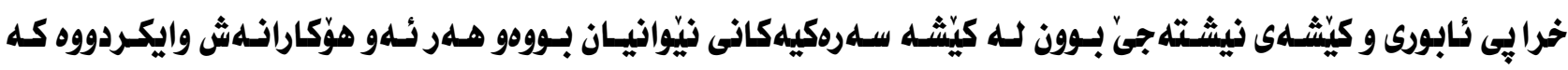

جيابنهوه.

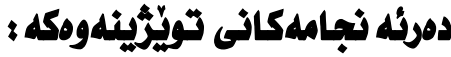

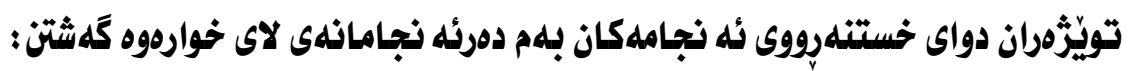

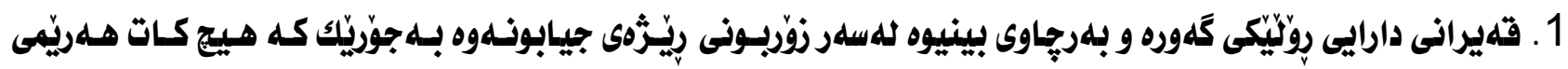

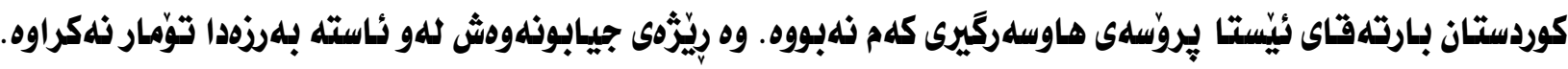

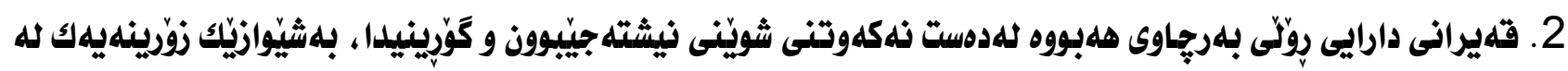

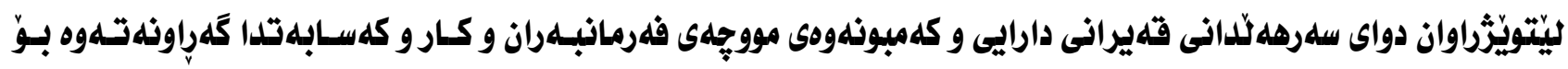




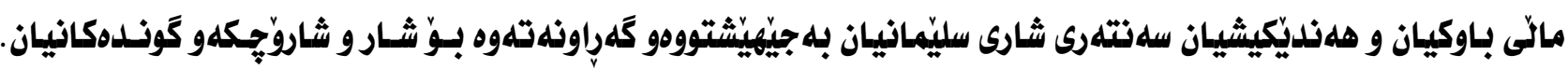

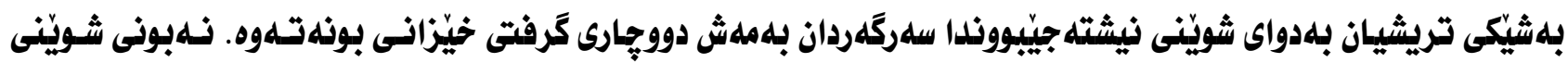
نيشته جيبِيوونيش به فاكتهريّكى سلهرهكى جيبابونهوهى نيّوان هاوسلهران دادهنريّت.

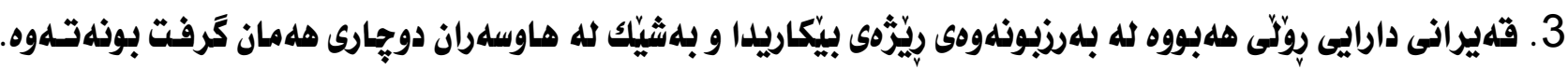

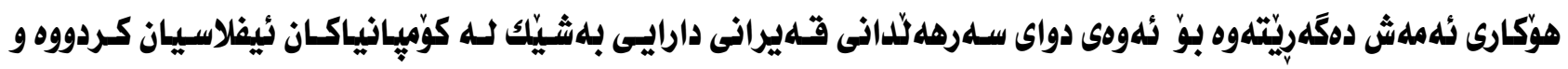

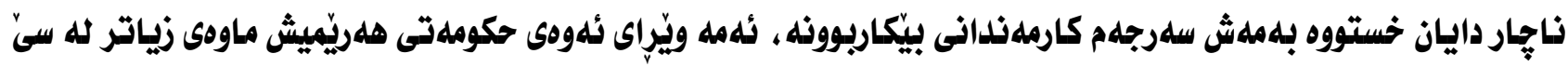

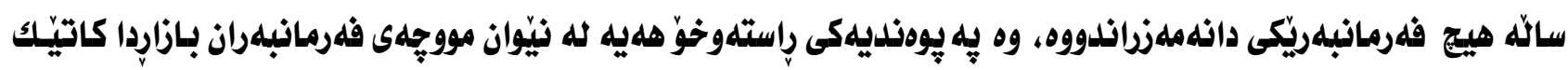

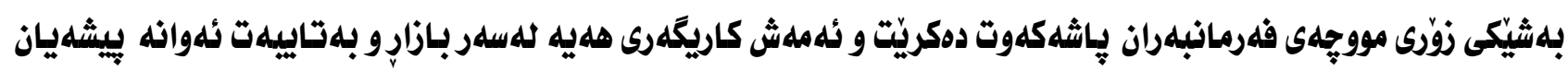

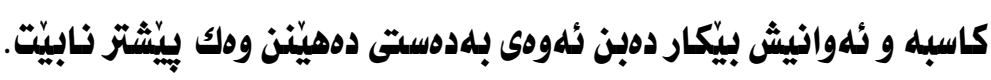

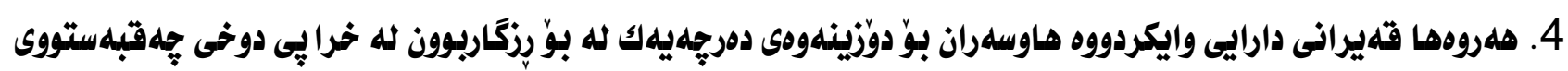
سياسى و نُابورى و كوّهل لاّيهتى بير له كوّجِكردن بوّ هلهندهران بكهنهوه.

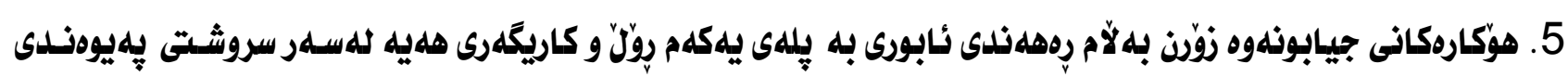

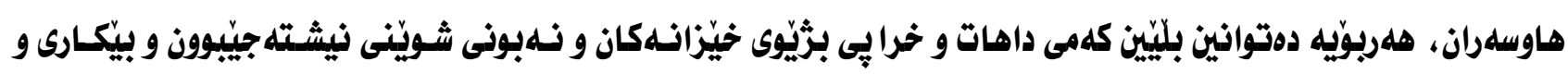

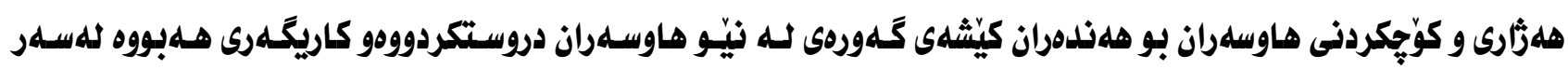
جيابونلهوهى هاوسلهراندا جـاوكى هلهموو ئهو كيّشانلش قهيرانى داراييهكهيه.

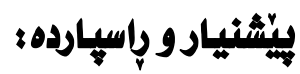

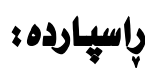

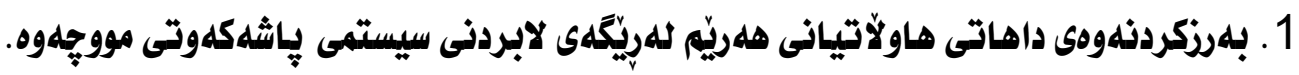

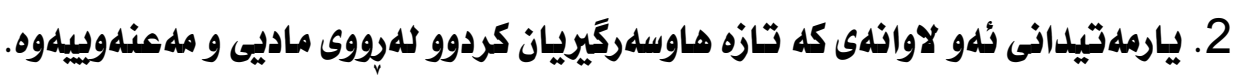
3. حكومهتى هلريّمى كوردستان كار للهسلر بـاشكردن و جيَّيركردنى بـازارهكان و دوّخى مووجيه خورّان و كاسبكاران بكات.

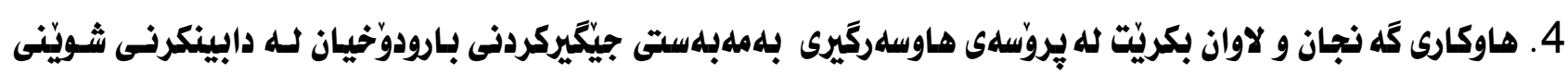
نيشتيه جيبِوونياندا.

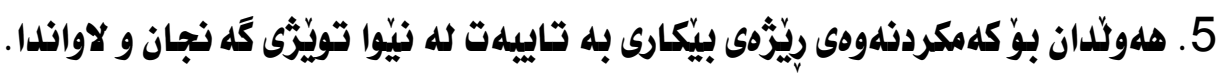

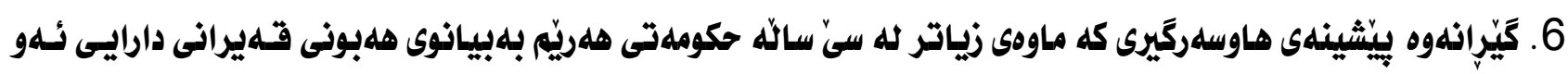
بيّشينهليهى وهستانلدووه.

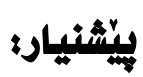

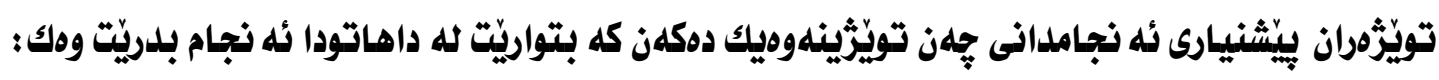

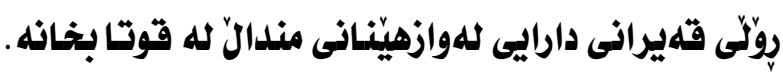

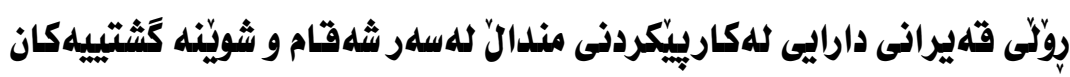


سلرجهاودكان

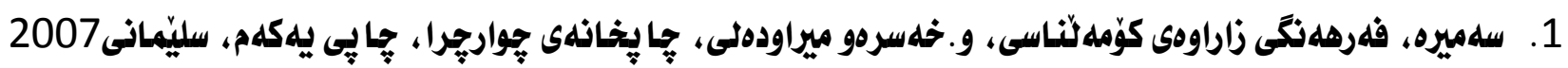

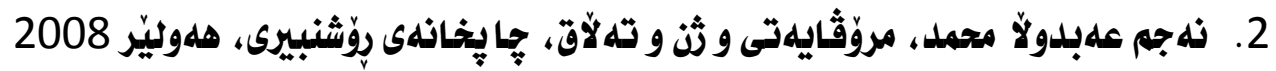

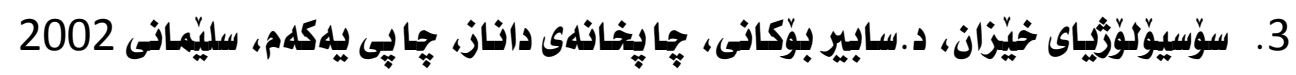

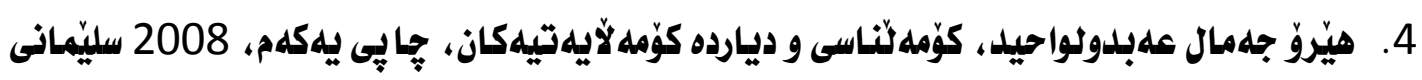

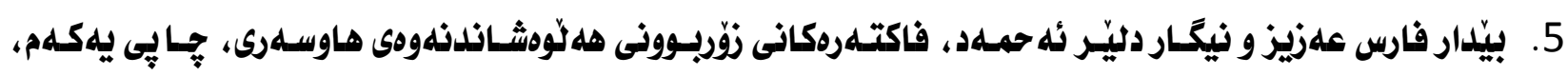
جا ڤايخانهى خانى، دهوّك 2005

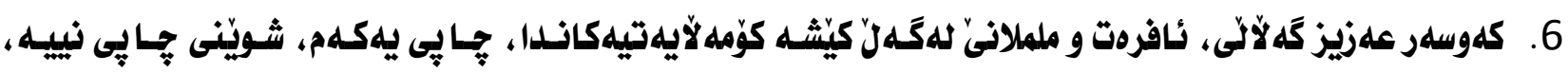
سليّمانى 2004

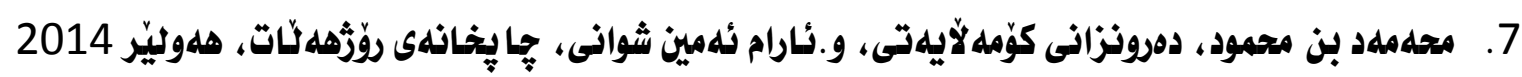

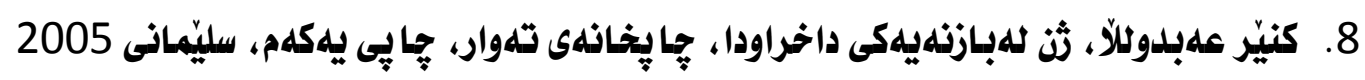

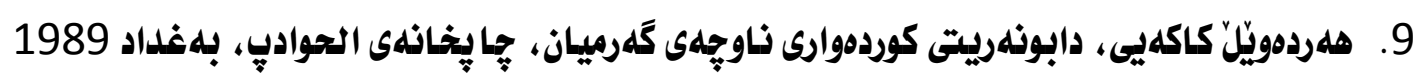

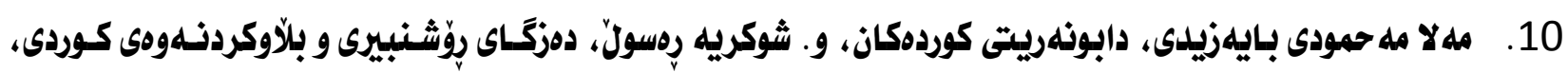
بلهغداد 1982

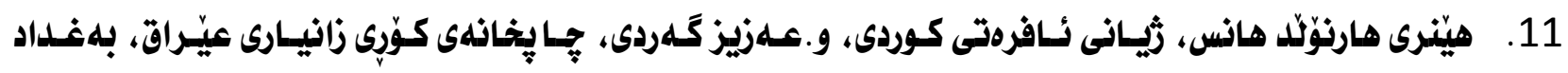
1983

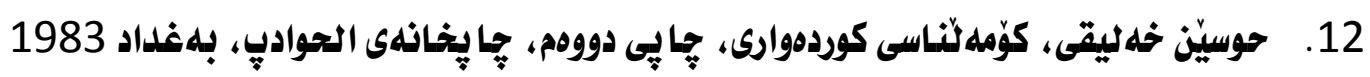

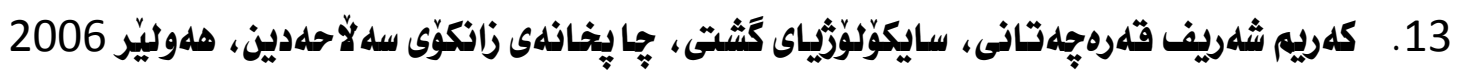

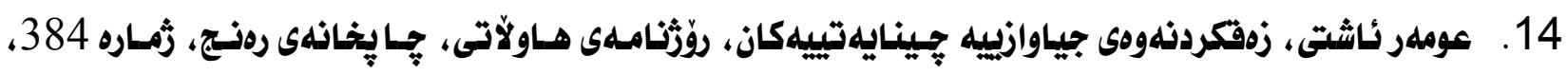
6У 2008

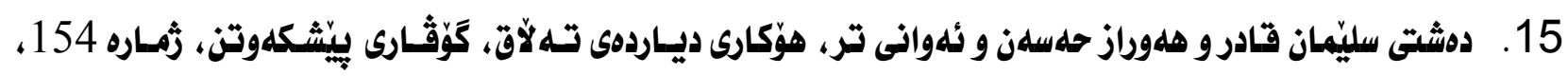

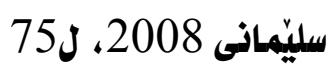

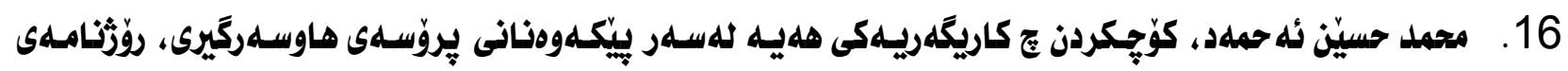

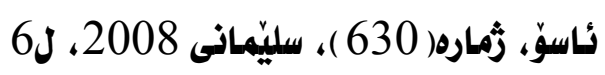

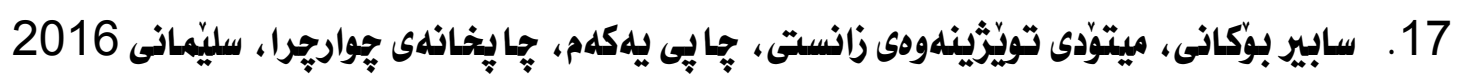

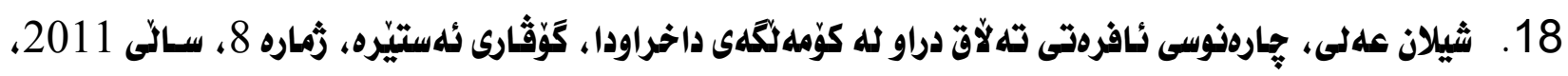
$6-5 \mathrm{~J}$

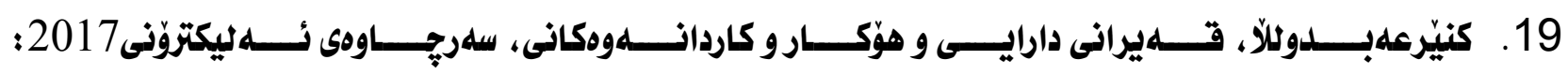
(2017-4-10) http://penus.krd/news364-65.htm 


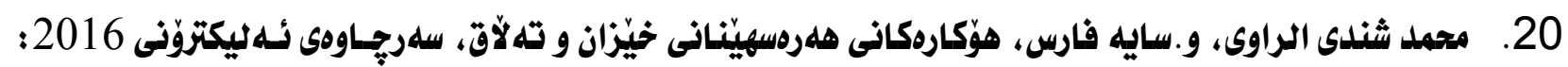

(2017-6-20) http://www.shanpress.com/details.aspx?jimare=5813

21. القرئن الكريه، سوره الآعراف، الآيه 31

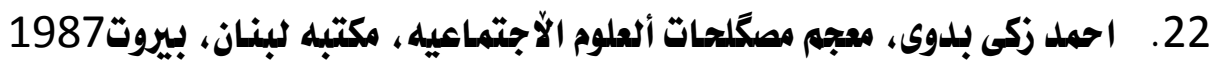

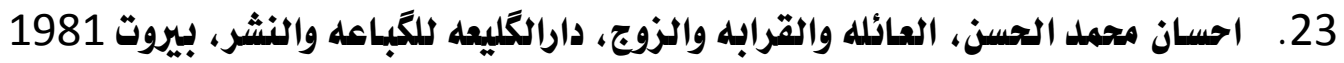

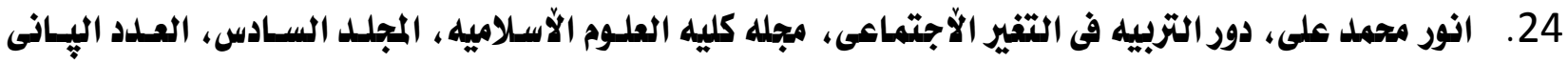

$$
\text { العشر، العراق - الموصل } 2012
$$

25. النجام الاقتصادى فى الاسلام، من منشورات حزب التحرير، التَبعه السادسه، دار الآمه للَّباعه والنشـر والتوزيع،

$$
\text { بيروت-لبنان } 2004
$$

26. مليحه عونى القصير و صبيح عبدالمنفم احمد، عله الاجتماع العائله، مكَبعه الجامعه بغداد، بغلاد 1984

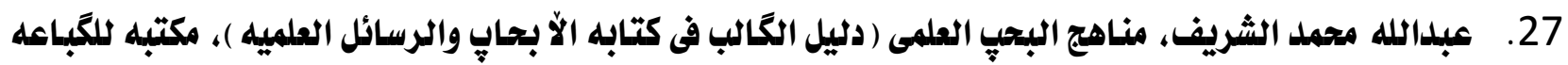

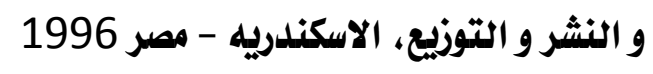

28. عايله احمد الرواجبه، العلاقه الزوجيه دون مصاعب ..كيف؟ گَّ، الكتبله اليقافيه، بيروت 2003

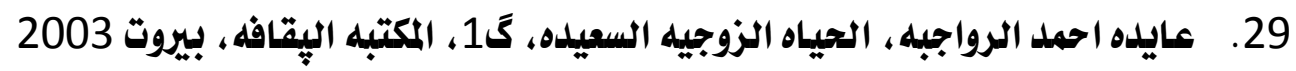

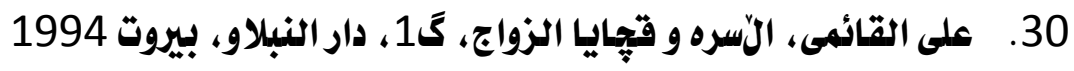

31. عفاف محمد عبدالمنعم، الآدمان ( دراسله النفسيه لاسباب ونتائجه )، دار المعريفه الجامعيه، القاهره 2004 32. فهمى الفزوى واخرون، المدخل الى علم الآجتماع، دارشروق، عمان 1992

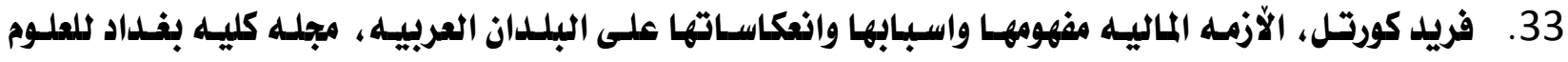
الاقتصاديه الجامعل، عدد 20، بغداد 2008 34. شومان منزر، الآعلام والزّمات، مدخل نثرى وممارسات عمليه، دار الكتب العلميه للنشر والتوزيع، القاهره 2003

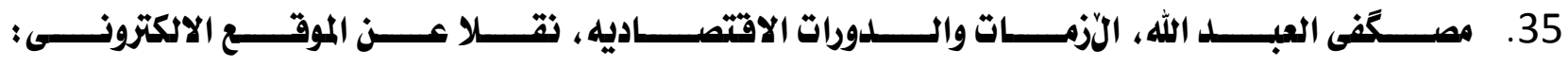
(2017-6-10 ) http://www.hewar.com/economics

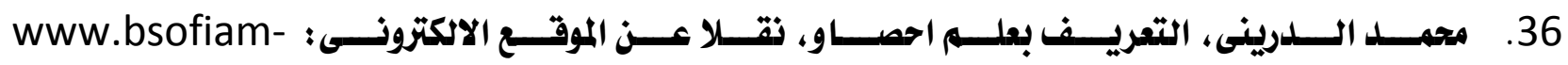
(2017-5-20) ksu.com/agec613/listure1.pdf 


\section{Abstract $\square$}

Family welfare is related with the welfare of husband and wife. The family and the relationship between husband and wife have seen the lion`s share from the changes happened in the circumstances of Kurdish community and because of this, the phenomenon of divorce according to the number of courts is above the natural rates compared to the large number of cases affecting the relationship .

This study is an attempt to present how financial crisis has its own impacts on this divorce. Is this crisis happened because of the lack of the husband and wife's role in the community or is it because of the normal life and the responsibility the families should take?

In order to reach to this conclusion، the researcher has done this work on the basis of the descriptive methods using the real analysis tool for information and recorded interviews .

The researchers analyzed the court's facts compared to the cases of years before the crisis and after the crisis and then they used interviews to therting cases of divorce as the reason for their divorce was the financial crisis.

Finally، we came to the result of that the high demand for divorce, the change in the way of life of the individuals and the economic crisis have a direct impact on the number of sides of life such as place of residence، unemployment and low salary ، all of which have destroyed the relationship of the past years of the families.

For this reason، the researchers proposed a reasonable proposal to solve these problems by issuing special instructions for the quality of relations and the distribution of responsibility among husbands and wives، except for proposing the government's cooperation in tackling the problem of salary and reducing unemployment among( youths) young people. 


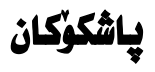

\section{(1)}

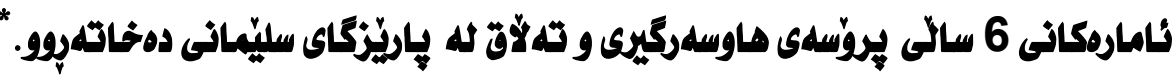

\begin{tabular}{|c|c|c|}
\hline جيابونهوه & ماوسهركيرى & سالز \\
\hline 2430 & 13724 & 2010 \\
\hline 4295 & 15414 & 2011 \\
\hline 4088 & 17020 & 2012 \\
\hline 4322 & 14911 & 2013 \\
\hline 4012 & 14666 & 2014 \\
\hline 4850 & 14232 & 2015 \\
\hline 4674 & 10937 & 2016 \\
\hline
\end{tabular}

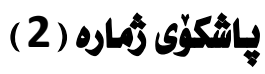

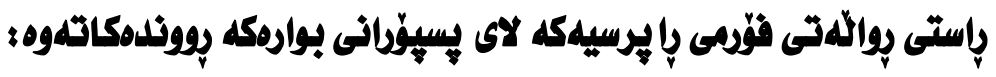

\begin{tabular}{|c|c|c|c|c|c|}
\hline رِيْرَهى سهدى \% & 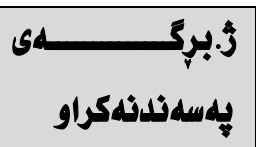 & لهُبهندكراو & بوارى يَّيوزى & ناو & 3 \\
\hline 88.2 & 2 & 15 & دهرونزانى & مستهفا مـ د. سـابير بـهكر & 1 \\
\hline 94.1 & 1 & 16 & درورنزانى & خالد حلهسله فخرالسلدين & 2 \\
\hline 88.2 & 2 & 15 & رإكلهياندن & محمد كــــاوه عبــــالرهزا & 3 \\
\hline 82.3 & 3 & 14 & كارى كوّمهلاًايهتى & د. لوقمان صالّح كهريم & 4 \\
\hline 76.4 & 4 & 13 & كارََيْرِي و ونابورى & بپ.ى.د خالد حهليدرد & 5 \\
\hline 85.84 & 12 & & 73 & & كؤ \\
\hline
\end{tabular}

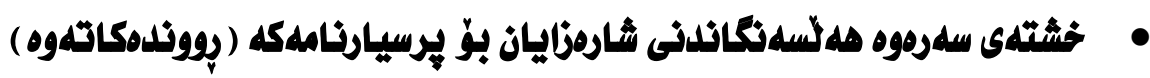

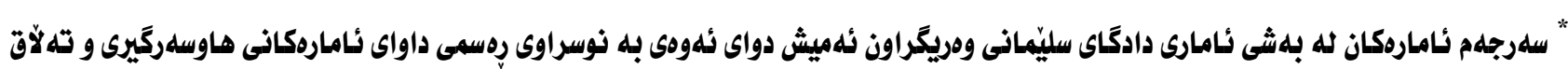




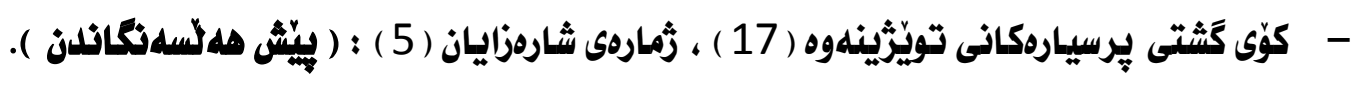

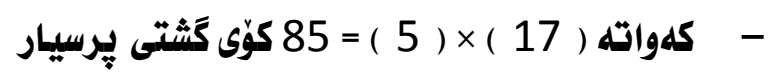

$$
\begin{aligned}
& \text { - } \\
& \left(\% 85.8<\frac{73}{85}\right. \\
& \text { - } \\
& \text { - }
\end{aligned}
$$

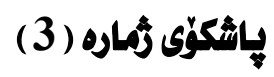

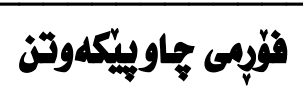

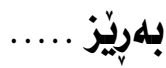

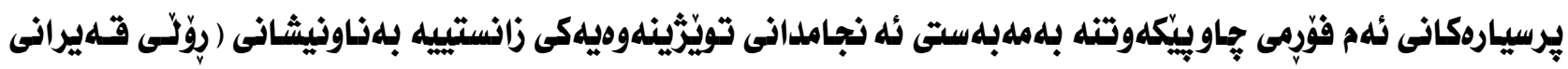

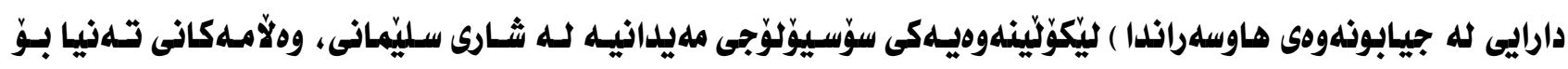

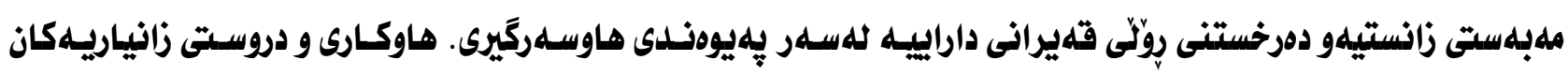
خزمهت بله رهوتى زانست و يِيشخستنى دمكات.

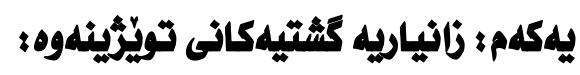

1 1

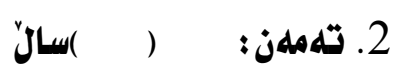

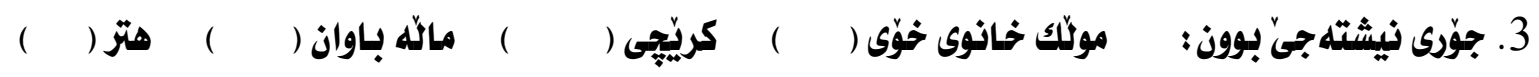
4. سائى هاوسلهركيرى:

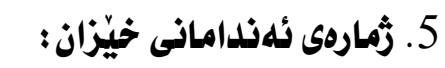

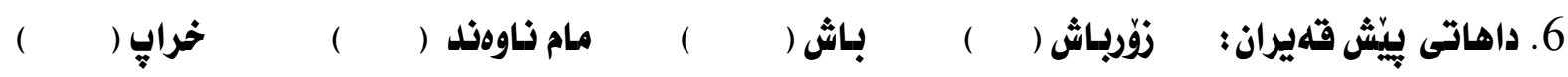

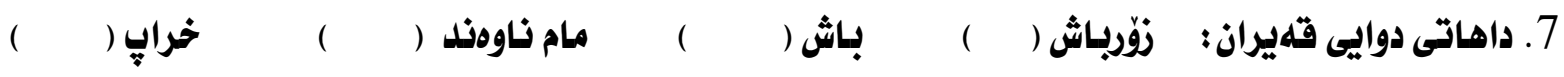

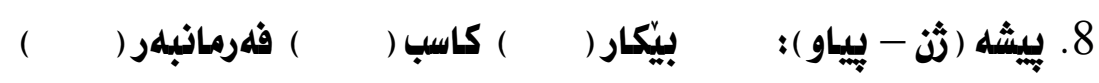

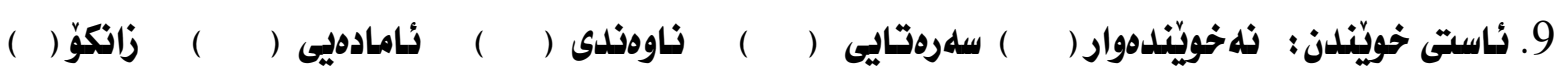

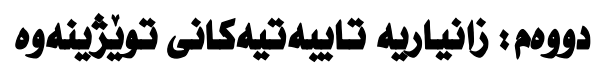
10. قهيرانى دارايى كاريكهرى هلبووه سلهر بيّلداويستى سهروتاييهكانتان؟

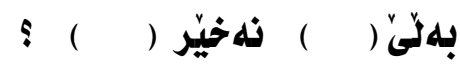




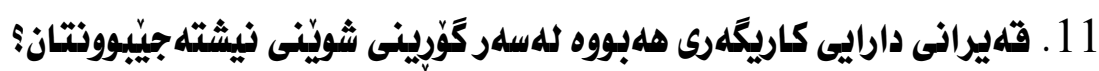

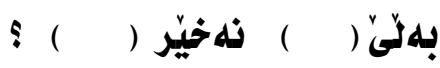

12. قهيرانى دارايى كاريكهرى هلبووه للهسلر كهمبونلوهى داهاتى مانگانهتان؟

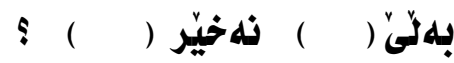

13. قهيرانى دارايى بوّتّه هوَى ثُلهوهى قهرزاربيت؟

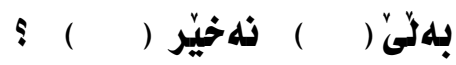

14. قّلهيرانى دارايى بوّته هوّى ئهوهى بيكاربيت؟

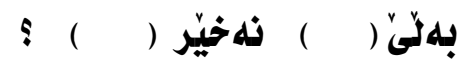

15. قهيرانى دارايى كاريكهرى كردوّته سلهر خهرجيلكانتان؟

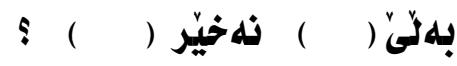

16. قهيرانى دارايى كاريكهرى كردوّته سلهر كواليتى زيانتان؟

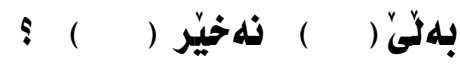

17 ـ دوايى سلهرهلَّلدانى قهيرانى دارايى بيرت له كوّجِكردن كردوّتهوه ؟

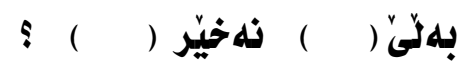

